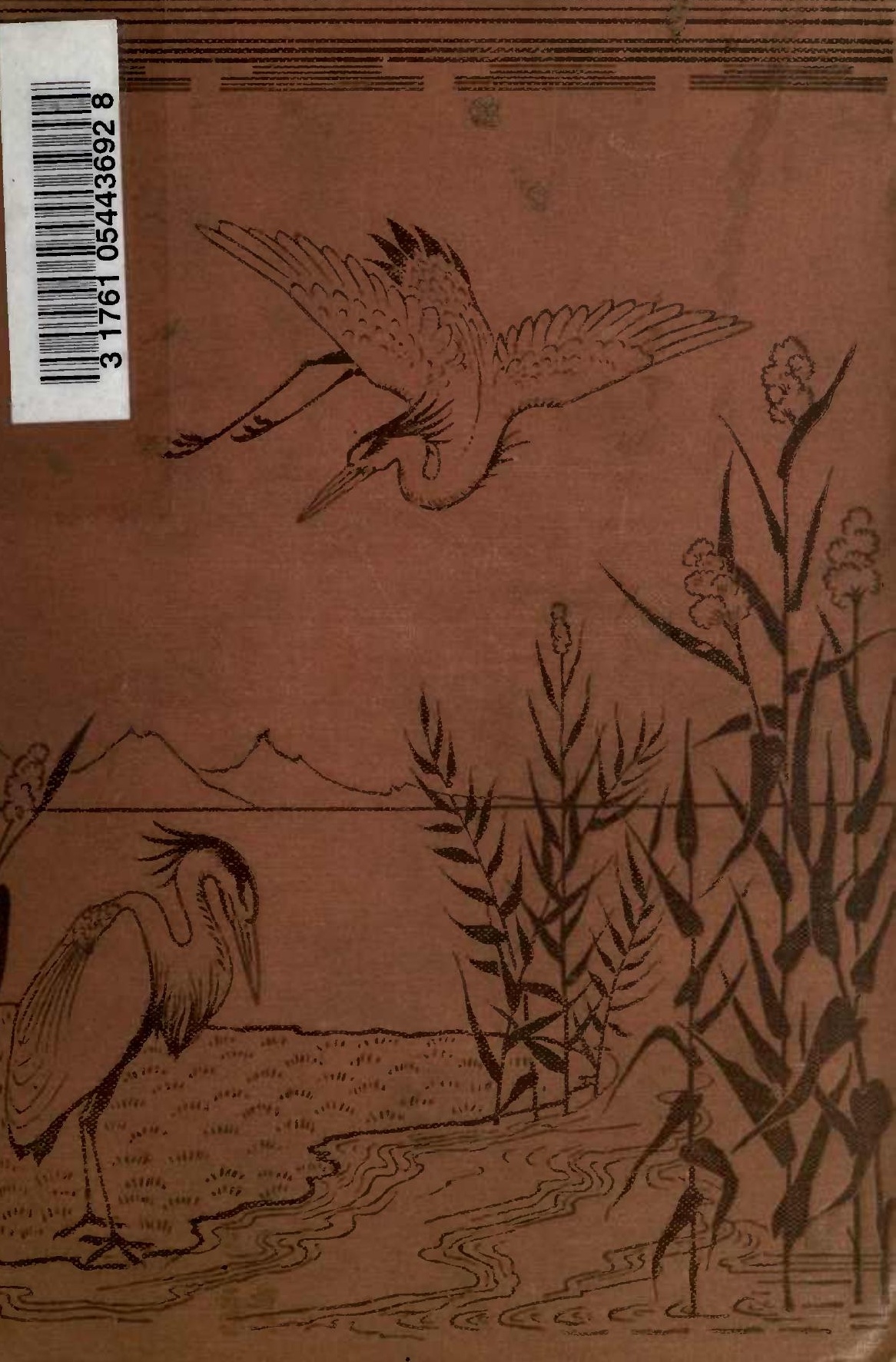







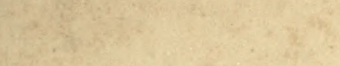

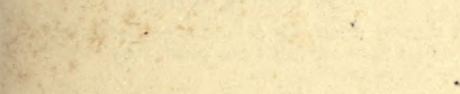




\section{THE EVOLUTIONIST AT LARGE. BY GRANT ALLEN.}

'On the whole, any one who knows natural selection in the general as a theory, but has not realised its varied applications in the most familiar facts of animal and vegetable life. can hardly find a better aid to his imagination than Mr. Grant Allen's volume ; and to those who already have any taste for natural history in the concrete, it may safely be recommended as a welcome holiday companion."

SATURDAY REVIEW.

'Nearly all the fresh lights which have been thrown upon the relations of the natural world by the teachings of Darwin and Herbert Spencer are here condensed and exhibited in the most simple gossiping style.'-NATURE.

'These essays are quite as much bits of literary art as bits of scientific exposition. They aim at awakening an interest in "the principles and methods of evolutionists" among unscientific readers, and they do so by means of a literary treatment that has something of the charm of Le'ssing's "Laocoon." ... Mr. Allen's readers will certainly hope that in hours of relaxation from heavier work he may throw off more of these delightful scientific vignettes.'-ACADEMY.

' Characterised by a tone of fresh experience and enjoyment of nature which the average scientific student lives through before he gains the power of speaking with authority upon questions of general interest. . . . It would be difficult to suggest a more pleasant travelling companion than this volume.'-WESTMINSTER REVIEW.

"Taken as a whole, the volume is one of the best specimens of popular scientific exposition that we have ever had the good fortune to fall in with. The author is a naturalist of the highest type; he has acquired an insight into the workings of Nature which nothing but a close personal study of her manifold processes can give; and his command of clear and impressive language is as complete as his knowledge is extensive.'-LeEds MERcury.

'There can be no doubt of Mr. Grant Allen's competence as a writer on natural history subjects. ... In the present volume he has selected such natural objects as may for the most part be met with in any country walk-a wild strawberry, a snail-shell, a tadpole, a butterfly, a bird, or a wayside flower-the more striking external features of which he seeks to explain by the light of evolutionary principles. . . The author is as much at home among plants as among animals, and probably his most enjoyable papers are those in which he discourses on the use to the plants themselves of the colours of flowers, the sweetness of fruits, and the hardness of nuts. The essaystwenty-three in number-are neitber long nor deep, but they give a broad general view of the principles and methods of evolution, couched in clear, untechnical, and oftentimes racy language, and are thus admirably adapted for their intended purpose.'

SCOTSMAN.

'Mr. Allen's method of treatment, as explanatory of the scientific revolution known as evolution, gives a sort of personality and human character to the trout or the strawberry blossom, which invests them with additional charm, and makes many of his pages read more like a fanciful fairy tale than a scientific work. . . . Mr. Allen's essays ought to open many a half-closed eye.'-MANCHESTER EXAMINER.

'We can recommend Mr. Allen's pleasant pages. As an instructive companion for a long journey, or as a book for a seaside holiday or country residence, it has a deep value in its suggestive topics, affording an incentive to gather the "harvest of a quiet eye." "-GLASGOw HeRALD.

CHATtO \& WINDUS, Piccadilly, W. 


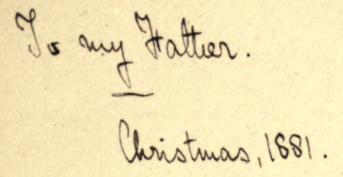

VIGNETTES FROM

NATURE 
LONDON : PRINTED BY

SPOTTISWOODE AND CO., NEW-STREET SQUARE

AND PARLIAMENT STREET 
BLOL

A

\section{VIGNETTES FROM NATURE}

BY

\section{GRANT ALLEN}

AUTHOR OF 'THE EVOLUTIONIST AT LARGE'

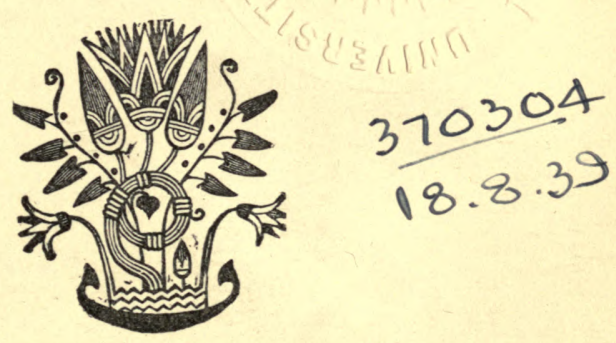

Pondon

CHATTO \& WINDUS, PICCADILLY

I 88 I 

CARISSIMAE

MUNUSCULUM INDIGNUM 



\section{PREFACE.}

These little Essays first appeared in the columns of the 'Pall Mall Gazette,' and I have to thank the Editor for his kind and courteous permission to republish them here. They were written in almost every case exactly under the circumstances which they describe, so that they form the record of a single summer's stray thoughts on Nature from an easy-going, half-scientific, halfæsthetic standpoint. Some of them were made up in Dorsetshire during early Spring ; some were suggested among the Welsh hills in July and August; and a few were drawn from Autumn scenes on the English South Coast in September and October. They 
have no pretension to be any more than popular expositions of current evolutionary thought, occasionally their author's, oftener still other people's: but they may perhaps do a little good in spreading more widely a knowledge of those great biological and cosmical doctrines which are now revolutionising the European mind, and which owe their origin to the epoch-making works of Charles Darwin and Herbert Spencer. 


\section{CONTENTS.}

I. Fallow DeER . . . . . I

II. Sedge ANd Woodrush . . . . . I 2

III. - Red Campion AND White . . . 22

IV. Butterfly-Hunting Begins . . . 3 I

V. Red Campion again : . . . $4 \mathrm{I}$

VI. The Hedgehog's Hole . . . . 50

ViI. On Musbury Castle . . . . 6 I

VIII. A Big Fossil Bone. . . . . 70

IX. VERONICA . . . . . . . 8 I

X. Guelder Rose . . . . . . 9

XI. The Heron's Haunt . . . . IO2

XiI. A Bed of Nettles . . . . . . II3

XIII. Loosestrife and Pimpernel . . 125

XIV. The Carp Pond . . . . . ${ }^{\mathrm{I}} 36$

XV. A Welsh Roadside . . . . I47

XVI. Seaside Weeds . . . . . ${ }^{1} 56$

XVII. A Mountain TARn . . . . 166 
XVIII. Wild Thyme . . . . . . 177

XIX. The Donkey's Ancestors . . . 187

XX. Beside the Cromlech . . . . 198

XXI. The Fall of the Leaf . . . 209

XXII. The Fall of the Year . . . 220 


\section{VIGNETTES FROM NATURE.}

$$
\text { I. }
$$

FALLOW DEER.

UNDER the great horse-chestnut trees in Woolney Park the broad circle of shade is now pleasant enough to attract the does and fawns of the fallow deer, who lie in pretty groups upon the grass, or stray about, browsing, beneath the heavy boughs thick with scented blossom. To-day I have brought out a few scraps of bread in my pocket, and the fawns are tame enough to come and eat it from my hand on the open; for they have less fear of man here than in any other place I know of, except perhaps in the Magdalen 
grounds at Oxford. They will even allow a favourite acquaintance to stroke and fondle their pretty heads. No doubt the long domestication of their ancestors has made them naturally prone to strike up a friendship with human companions, just as is the case with kittens and puppies; and at Woolney they have always lived very near the great house itself, where children and visitors have long been wont to pet and caress them. There are, indeed, few more interesting relics of the past in England than these stray herds of dumb creatures, remnants of the native woodland tribes which once spread over the whole well-timbered country, and which now carry us back in mind past the days of Robin Hood and of William the Red to the old forestine life of the Celtic and Euskarian aborigines. For though some good authorities will have it that the fallow deer date back no earlier in this country than the days of the Romans, who are said to have introduced them for their pleasure grounds, I myself 
can hardly doubt that they are a part of our old indigenous fauna, which now survives only in a few enclosed preserves. The wild white cattle at Chillingham, the red deer on the Scotch moors, and these pretty does and fawns in Woolney Park, all trace back their ancestry, I believe, to the time when England was clad by one almost unbroken sheet of oaks and beeches, and still earlier to the time when a great belt of land connected it with the Continent from Holland to Portugal. Even the veriest Red Radical like myself may well share John Mill's hope that the spread of agriculture and political economy may never succeed in improving these dear dumb friends and pensioners of ours off the face of the earth. They are one of the beautiful links which bind us to the præ-human past; and I hope we may hand them on as part of our common heritage to those who will follow us hereafter in a higher and more human future.

Evolutionism, it often seems to me, throws 
a wonderful charm of this half-historical sort around every beast or bird or plant in the meadows about us. These fallow deer are no longer mere accidental animals happening to live in the park here at the present day: they are creatures with a whole past history of their own, as interesting to the eye of the evolutionist as a castle or an earthwork to the eye of an archæologist, and as a cathedral or a temple to the eye of Mr. Freeman or Mr. Fergusson. We have all been living all our lives in the midst of a veritable prehistoric Ilium, with all its successive deposits and precious relics lying loose about us, and we needed only a Schliemann to tell us what it all meant. Mr. Darwin and Mr. Herbert Spencer have read the riddle for us, and in doing so they have given us a key which will help us to unlock, each for himself, a thousand little secrets of nature that meet us every day, on our way through the world, at every turn. These fallow deer, for example, have a quite recoverable pedigree, which shows us just by 
what steps they have been developed from an early common ruminating ancestor; and this pedigree M. Gaudry has worked out for us in detail as admirably as Professor Huxley has worked out the genealogy of the horse, and as Dr. Mivart has worked out that of the cat.

The very earliest ruminants whose remains we meet with in the lower tertiary strata were all hornless. They resembled in this respect a few abnormal living kinds, such as the camels, the llamas, and the alpacas, though, of course, these kinds are far more specialised in other ways than were their primitive ruminant ancestors. But as time went on, the wager of battle among the males, common to so many races of mammals, produced singular results upon the whole ruminating tribe. The nature of their food prevented them for the most part from fighting with their teeth, like carnivores, so they took to butting with their heads instead. Thus, either by accidental variations, as $\mathrm{Mr}$. 
Darwin thinks, or by use and wont, as $\mathrm{Mr}$. Herbert Spencer rather believes (with more probability, as it seems to my humble judgment), aided in any case by natural selection, almost all the ruminants grew at last to have horns or antlers of one kind or another. But these weapons of rivalry-for they are all but useless against other species-differ greatly in their structure, and therefore in their origin, between race and race. All that is constant is the presence of some kind of offensive butting instrument upon the forehead. In the bison and ox tribe, including the antelopes and goats, the weapons take the form of real horns - that is to say, of hollow permanent dermal processes; in the deer tribe they appear as antlers-that is to say, as deciduous bony, not horny, structures; and in the giraffe they exist in the shape of permanent bosses of the skull, covered with hair and skin, but used very fiercely in combat, even in Regent's Park, where one giraffe once actually drove his horn clean into the 
skull of another. Only one very abnormal ruminant, the musk deer (which is not really a deer at all, but a specialised aberrant descendant of the old undifferentiated ancestral type) has weapons of a different character - a pair of curved tusks in the upper jaw, used in the same way as those of the wild boar.

The historical development of antlers in the deer tribe is very marked. While the group was still young and dominant, with the open grass-clad tertiary plains all before it, and. with plenty of elbow-room to spread and multiply, it had as yet no weapons of offence of any kind. But as the races grew thicker and more numerous, and as space failed the younger generations-for deer, like men, are subject to the inexorable logic of the Malthusians - the fathers of the herd began to fight among themselves for the possession of the does, and only the strongest survived to become the parents of future deerkind. Butting naturally produces hard bosses or 
protuberances of some sort ; and in the ancestral deer these protuberances took the shape of bony projections on the forehead. Again, those deer which had the most marked and most pointed projections would best vanquish their rivals, and so fare best in the struggle for the hinds. Their descendants would inherit their peculiarities with more or less variation; and would similarly be selected by the law of battle in accordance with their fighting powers and the fitness of their weapons.

Now this probability, set forth $\grave{a}$ priori by Mr. Darwin, exactly tallies with the geological record, as interpreted by M. Gaudry and Professor Boyd Dawkins. The very vague and unspecialised deer of the lower miocene period had no antlers at all : they were somewhat like musk-deer without the tusks, or like young fawns in their first summer. But in the mid miocene, antlers make their first appearance as mere short pointed knobs; next, they develop a single side tine; and in 
the upper miocene they come out as fully evolved as in our modern species. Every intermediate stage can be traced between the mere nascent boss like that of a budding roe in our own day, and the many-branched headpiece of the existing reindeer. Indeed, one late tertiary species had a pair of wonderfully intricate antlers which far surpassed in complexity those of any living elk; but, like many other highly specialised creatures, this overdeveloped type seems to have fallen a prey to the great extinct carnivores of the same period. Before the advent of man, many such high types existed, and they may perhaps have been partly destroyed by his monopolising all the most open and desirable plains as his special hunting grounds. For we now know that man is certainly a quaternary, and probably a tertiary genus as well; and, even in his lowest and humblest form, his intelligence must have made him from the very first a dominant race and the real lord of creation. 
It is interesting to note, too, that the historical evolution of antlers in the deer tribe is exactly paralleled by the modern evolution of antlers in every individual red deer. In the first year a stag has no horns at all, and is technically known as a calf. In his second year he puts forth a pair of rounded bosses, and is therefore called a knobber in the slang of the gillies. With his third year the knobs fall off, and are replaced by longer horns, called dags, while the stag himself is now known as a brocket. Thus, year after year, the growing deer reproduces one stage after another of the ancestral development, till at length the top of the horn expands into a broad crown, and the beast is then finally dubbed a hart or 'stag of ten,' from the number of tines on each of his antlers. It would be quite possible to pair the cast horns of each year tolerably exactly with corresponding adult horns from the successive tertiary strata. Every deer in fact recapitulates 
in his own person the whole evolution of his race, the antler of each successive year being different, not only in size but in form and arrangement as well, from those of all previous seasons. 
SEDGE AND WOODRUSH.

Sitring here on the edge of the low wall that banks up the meadow against Cannington Lane, I can pick without stooping half a dozen different kinds of grassy-looking weeds, all within easy reach of my hand in the field behind me. The sun is shining brightly through the horse-chestnut branches, the west wind is blowing gently over the valley, and the day is warm enough to tempt a little loitering under the scanty shade of the young foliage overhead; so I cannot do better than pick and examine a few of these unnoticed flowers, whose pale yellow spikelets are hardly conspicuous enough to attract the 
notice of any save a botanical eye. Grass; most people would call them; and indeed their leaves are grassy-looking blades enough; but a single close glance at their reedy stems and clustered flower-heads would suggest even to the unpractised observer that their stalks and blossoms differed widely from the little scaly panicles of the true grasses.

To my thinking, there are few plants so pretty as all these small insignificant-looking unconsidered weeds, whose flowers need to be examined somewhat minutely before we can fully appreciate the real beauty of their form and arrangement. Anybody can see and admire at once a foxglove or an orchid, but not everybody can see and admire at once the delicate gracefulness of spurges and quakegrasses, of little waving sedges and tufted woodrushes. One feels that the beauty of the larger blossoms is something flaunting and meretricious - an Aphrodite Demosia tricked out in gaudy colours to please the 
most careless passer-by; whereas the tiny green and brown flowers of the fields and hedgerows appeal to a more esoteric circlea select few who can sympathise with nature in her more sombre as well as in her brighter moods. L'Allegro is the world's side of nature, but Il Penseroso is the poet's.

Look, for example, at this tall stalk of woodrush, its stem clasped by two or three drooping and pensile leaf-blades, and its top crowned by four or five thickly clustered heads of small brown five-rayed flowers. At first sight you would say it was merely a bit of grass with a brownish top to it; but gaze a little closer and you will see that the heads consist each of half a dozen tiny regular blossoms of a very pretty fantastic sort. Each blossom has six dry brown petals, with silvery thin transparent edges; and in the middle, as many bright yellow stamens stand out delicately against the brown background of the corolla. Every one of them is like a sombre copy in miniature of a lily or an 
amaryllis, not very striking to a careless observer, but marvellously pretty and perfect when you look attentively into the tiny rosettes. And the history of these dry brown flowers is in itself curious enough to make them well worth a moment's examination. For the woodrush is almost undoubtedly a faded and colourless descendant of some once coloured and brilliant ancestor. You may be fairly sure of that from the mere look of the dry brown petals. Every blossom with petals, however small or green or inconspicuous, has once been a bright and flaunting flower; for the sole object of petals is to attract the eyes of insects, and they are therefore found nowhere but among insectfertilised plants or their degenerate descendants. Flowers which have always been fertilised by the wind never have any petals at all, brown, green, or otherwise ; but flowers which are fertilised by insects have them red, white, blue, or yellow; and flowers which have once been so fertilised and have after- 
wards relapsed almost always retain some memorial of their old estate in the shape of dwarfed and colourless petals, whose function is gone, while the rudimentary structure still survives. They point back, like the fasces of the Byzantine emperors, to the past glories of their race in earlier times.

Our fields are full of such degenerate flowers, with green or brown corollas, sometimes carefully tucked out of the way of the stamens, so as hardly to be seen unless you pull them out on purpose ; for, contrary to the general belief, evolution does not by any means always or necessarily result in progress and improvement. Nay, the real fact is that by far the greater number of plants and animals are degraded types-products of retrogression rather than of upward development. Take it on the whole, evolution is always producing higher and still higher forms of life; but at the same time stragglers are always falling into the rear as the world marches onward, and learning how to get 
their livelihood in some new and disreputable manner rendered possible by nature's latest achievements. The degraded types live lower lives, often at the expense of the higher, but they live on somehow; just as the evolution of man was followed by the evolution of some fifty new parasites, on purpose to feed upon him.

It would be wrong to suppose, however, that these dry brown petals in the woodrush have now no function at all: they have found out a new one to which they have adapted themselves, although the old one of attracting insects has passed away. Whenever and however the woodrush took once more to the primitive and wasteful method of fertilisation by the wind we cannot say. But it is a low, lithe, grass-like plant, growing with the grasses in the wind-swept meadows; and almost all the plants of the same habit and habitat are wind-fertilised as well. Living, as they do, in great numbers close together, with bending stems and often 
feathery heads, they do not seem to waste so much pollen as other, taller, and more scattered flowers would waste, if obliged to trust to the breezes alone for its dispersion. At any rate, almost all wind-fertilised plants are obliged to have some plan for preventing the pollen of each blossom from falling upon its own pistil, and so producing poor, weak, self-fertilised seeds. They almost always display some curious device, to ensure a cross with the neighbouring flowers. In the woodrush the thin papery petals have been utilised in a manner subsidiary to this new object. They were no longer of any service in attracting insects, but they have been very simply diverted to another function. Here I have picked one of the younger heads with the blossoms yet unopened. From the top of each flower a long white plume of three waving filamentsa Prince of Wales's feather in miniatureprotrudes through the tightly closed petals. These plumes are the sensitive surface of 
the pistil; and to them the pollen-grains are blown from other surrounding blossoms, already fully opened. As soon as the seeds have thus been impregnated, the little plumes wither away, and then the petals, which have hitherto covered the stamens, open immediately, releasing the stamens, as you see them in the first head I plucked. The pollen blown from them falls upon some other flower still in the bud; and so each head as it opens fertilises in turn its unopened neighbours. You can gather lots of them here in every stage of blossoming, from the first receptive period with hanging plumes and tightly covered stamens, to the last distributive period with open petals and stamens shedding freely their golden pollen-grains.

This pretty nodding sedge, on the other hand, shows us another way of solving the self-same problem - how to prevent the pollen from falling upon the pistil of its own blossom. The sedge has done it very simply, by putting all the stamens in one 
head of flowers at the top, and all the pistils in another head at the bottom. Look closely into this plant again, and you will see at once that it has gone even further than the woodrush on the downward path of degradation. It has no trace of petals at all; indeed, it is possible that it has never had any; though, judging from its close relations and the numerous intermediate forms, it is more likely that it once had them, but has now hopelessly lost them-as hopelessly as the snake has lost its legs. However this may be, the flowers of the sedge are now arranged in a thoroughly business-like manner for wind fertilisation. Each stalk bears three or four little branching spikelets, the top spikelet consisting altogether of yellow stamens, covered in groups of three by single russet-black scales, while the lower spikelets consist altogether of pistils, with two or three white feathery plumes hanging out to catch the pollen, and similarly covered by dark sheathing bracts. The whole head 
thus looks like a group of miniature catkins, the upper catkins bright yellow and the under ones delicately frosted with fluffy white. The use of this arrangement is obvious. When the wind shakes the heads so that they bend and jostle against one another, the tallest spikelet on each stalk naturally strikes against the lower spikelets of its neighbours. Thus each plant fertilises the next in order ; and even if the heads do not happen to touch, yet the pollen blown from the one falls forward upon the other, so producing exactly the same result. Indeed, cross-fertilisation is brought about in different plants by a hundred such devices; and to observe the various mechanisms by which it is furthered, forms a fresh and almost endless pleasure for every country walk. 


\section{III.}

RED CAMPION AND WHITE.

THE bank along the footpath that leads from the village to Culverhole Cliffs is just at present all aglow with a varied wealth of flowers and insect life. The yellow cabbagebutterflies are flitting over the blue masses of wild hyacinths; the ladybirds are busy among the wee green aphides on the budding sprays of honeysuckle ; and the bronzedmailed beetles are hunting for smaller insects beside the matted stems and roots of the big white stitchworts. The gorse has burst into its wonted blaze of blossom, so bright that one can hardly wonder at Linnæus, who fell upon his knees and thanked God with 
fervour when first he looked upon its golden glory. Up to this morning I have counted seventy-eight kinds of wild flowers in blossom, not including catkins or grasses. And now to-day, for the first time this season, I see the pretty pink clusters of the red campion adding their warmer tint to the blues and yellows and greens of the tangled bank beside me. Already the butterflies have found out that its big swollen buds have opened and made clear the way to the nectaries; and I can notice a great bustling hairy bumble bee blundering about the mouth of one flower on the stalk, while half a dozen little flies are gathered around the sticky calyx of another. Evidently the red campion is very successful in its efforts to attract the eyes of insects. I saw it distinctly a hundred yards away, and the butterflies seem to see it quite as well, and a great deal more effectually.

The campions, indeed, are flowers in which specialisation and adaptation have in 
many respects been carried to an extremely high pitch. True, they cannot compare in complexity with the orchids or the deadnettles, nor even with the little daisies and dandelions around them. Yet in their own way they have found themselves a place in nature which they are well fitted not only to fill but also to adorn. There are two common kinds in England, known to botanists as the day and night lychnis respectively, but to village children as red and white campion. The correspondence of these two names is full of significance. The day lychnis has a bright pink blossom, quite scentless, and opening in the morning. It is specialised for fertilisation by bees and butterflies (more particularly the latter), which are colour-loving insects, and which hunt by sight mainly, always during the hours of sunlight. The night lychnis, on the other hand, has white blossoms, opening in the evening, and faintly scented with a vague but pleasant perfume. It is specialised for fertilisation by moths, 
which fly at night, and which have sight not adapted to the perception of colour. Mr. B. $T$. Lowne has made some interesting microscopical studies of insects' eyes, and has shown that the eyes of moths correspond to those of owls among birds, in the absence of certain nervous elements supposed to be the organs of the colour sense; while the eyes of bees and butterflies correspond to those of day birds in the presence of such organs. In fact, it is clear that a colour sense would be of little use to nocturnal or crepuscular animals, because the amount of light in the evening is seldom sufficient to show up the distinctive colours of different objects.

Hence almost all the flowers which appeal specially to the moths are either white or pale yellow-good reflectors in the twilight or moonlight-and they are invariably scented, sometimes very strongly. Many of these white and perfumed night blossoms are great favourites in our gardens and conservatories-for example, jasmine, stephanotis, 
tuberose, and night-flowering cereus. Some of them actually close up during the day, and most of them emit their perfume only in the evening when the moths on which they depend for fertilisation are abroad. Moths, indeed, hunt mostly by smell, though they are also partly guided by sight, and perhaps even in part by the faint phosphorescence, hardly visible to human eyes, which, as the daughter of the great Linnæus first observed, plays lambent over certain of their favourite blossoms in the early shades of night. I have seen this phosphorescence myself (or fancied I saw it) on the petals of the evening primrose; but.only a few people have weak enough vision to detect it, for, like negative images, it cannot be seen by persons of robust and vigorous sight. Women and artists perceive it oftener than men of science, which no doubt tells rather hardly against its objective reality. Yet perhaps they and the moths can see some things which are hidden from the wise and learned; at least, 
I like to believe so, and to persuade myself that $I$ too am in this matter on the side of the poets.

The differences between the two campions, to return once more to solid science, form a very instructive study in the origin and growth of specific distinctions. In most points the two plants are absolutely alike, and even the technical botanists, who never miss a chance of manufacturing a new species where possible, admit that they are perhaps mere varieties of a single form. But then these varieties, especially when so markedly dependent upon difference in function, are nothing less than new species in the making. They are nascent stages of fresh types. An accidental variety of leaf or flower, like the monstrosities which we cultivate in our gardens, means, as a rule, very little indeed, because it is not correlated with any need or habit of the plant. It affords no material upon which natural selection can work. But a variety like the white campion has of course 
a distinct meaning, and is itself already the product of much selective action. That the white form, not the red one, is the divergent variety, we may infer from several peculiarities, notabiy from the fact that most of the lychnis tribe have pink flowers, and that no other British species has white ones.

Suppose, however, that some of these pink campions take (at first by some accident) to opening at night, then they may perhaps chance to attract the eyes of some passing moth, and so to get fertilised by the insect in its search for honey carrying the pollen from head to head. Thus a second generation of night-flowering -campions would be set up, still with bright pink blossoms. But the colour of petals is always more or less variable, being only kept straight by functional needs; and so some of these evening varieties would be pretty sure to have more faded and whitish flowers than others, and these would best attract the eyes of the fertilising moths, and oftenest accordingly succeed in 
setting their seed. After long generations of such unconscious selection, the white-petalled individuals would establish themselves as a permanent race; though even to this day the original pinkiness of their constitution has not wholly died out. It reasserts itself from time to time; for you may often find scented evening campions with very pale pink petals, recalling the old type of the race, just as amongst ourselves a particular bone, or tooth, or eyebrow sometimes still recalls the ancient. anthropoid peculiarities. By somewhat the same process the extra attraction of scent must have been acquired. Even the date of flowering has accommodated itself to the new conditions, for the red campions are now all coming into blossom and will soon be out in every hedgerow, while the white ones do not open for at least another fortnight. There are plenty of butterfies now in the warm sunshine at noon; but the nights are still far too chilly for moths to venture out as yet from their comfortable cocoons. A white 
lychnis flowering this week would therefore find its life thrown away, with no friendly insect at hand to help it in setting its precious seeds. Thus all those which blossomed too early have been slowly weeded out, and only the late-flowering individuals have at last been left to perpetuate their kind. 


\section{IV.}

BUTTERFLY-HUNTING BEGINS.

THE Lammas Fields are now positively thick with various butterflies, so I have come out this brilliant afternoon to watch and make notes, as my wont is, on their habits and manners. The first of May is to the naturalist what the twelfth of August or the first of September is to the sportsman-it is the real opening of his year, the date when flowerhunting and butterfly-hunting both begin. On the 2nd, in spite of backward weather, the cabbage butterflies were already airing their sulphur-yellow pinions in the sun, above the tall lilac sprays of the lady-smocks. Two days later the dragon-flies were darting after 
midges above the boggy hollows, and the banded hedge-snails were congregating in numbers among the young pale-green foliage of the hawthorn bushes. On the 7 th, we had a cloudless blue horizon and warm sunshine, and I saw an orange-tip plimming its unexpanded wings and displaying its beautiful markings on a blade of grass beside the brooklet. This evening, under a mackerel sky, like July weather, I have just been watching a motionless bunch of dry brown leaves on the hedge bank. Suddenly one of the leaves gets up, flutters about in the air a bit, and then settles down again on another brown cluster, a few yards off. I creep slowly up towards it, and examine the locomotive leaf as it stands. It is a little brown butterfly, with folded wings, fresh from the chrysalis; and the lower or outer surface, which alone is visible as it sits, seems dappled over with wee light spots, much like the spots of decay upon the leaves among which it hides. I clap my hands briskly, and it gets 
up hastily, opens its wings to the sunshine, and shows itself off at cnce as a red-streaked beauty in all its glory. It is not difficult to see that the difference of colour in the two sides of its wings must be designed for some special purpose, and that the purpose of the under side is to escape detection, while the purpose of the upper side is to attract attention.

The protective use of the brown underwings is very simply explained. The insect must be much exposed to birds and other hostile creatures as it sits still, and so it requires to resemble the ground, leaves, or twigs, on which it usually settles, in order to deceive the eyes of its enemies. To some people it seems that so slight a protection as this could scarcely be of any use to the butterfly. Natural selection, they say, can hardly work upon such petty differences. But to talk so is really to show a misapprehension of what natural selection rightly means. Every butterfly which is spotted by 
a bird, and so devoured, is wiped out of existence for ever, with all its possible progeny. Every butterfly which escapes, by however slight a peculiarity, is enabled to lay its eggs in peace, and to hand on its peculiarities to its posterity. This sort of selection is going on every day around us, and no difference is too slight for it to select, no resemblance is too clumsy provided it once for a moment aids the insect in avoiding destruction.

Now, we all know that the eyes of birds are very sharp and keen indeed. A hawk soaring so high in the sky that human sight fails to perceive it, will yet discriminate and pounce down upon a lark in the fields below -a small brown bird seated upon a brown clod of earth exactly like itself in colour. In just the same way the insectivorous birds keep a sharp look-out for moths and butterflies, upon which they swoop at once whenever they distinguish them upon the ground beneath. Every day those insects whose 
colour betrays them get thinned out by their watchful enemies, while those whose colour protects them manage to lay their eggs in peace, and hand on their own peculiar spots and lines to their descendants. The consequence in the long run is that the butterflies get better protected from generation to generation, as the chances of interbreeding with badly protected individuals are eliminated by the action of the birds, while only the most imitatively coloured individuals are left to mate with one another and to become the parents of future swarms. Thus the hostile birds are themselves the instruments through which the insects have been armed defensively against their depredations. For the various individuals tend always to vary a little in marking-no two plants or animals of the same species are ever exactly alike-but the picking off of the brightly. coloured individuals by the birds helps to. preserve the protected specific type intact. And of course the same causes which now: 
preserve it originally produced it. Ever since birds and butterflies have existed, the process must constantly have been at work ; and the birds and butterfies themselves, in the forms that we know, are the final outcome of its perpetual interaction.

This sufficiently accounts for the imitative colouring of the under surface, but it does not sufficiently account for the brilliant and attractive hues of the upper side. Those hues were probably produced in a very different manner. At this exact moment I see two red admirals above the hedge yonder, engaged in their pretty rhythmical courtship, flying round and round one another, now on top and now beneath, chasing each other in graceful curves, and seeming to be engaged for ten minutes at a time in a sort of aërial quadrille. These two butterflies are helping in their small degree to keep up and intensify the beautiful colours of their race. They are coquetting and flirting together, each eager to display all its charms to the best advan- 
tage, and to attract the other by its own beauty. If a third and prettier butterfly happens to sail up, the belle will bestow her affections upon the new-comer, and the vanquished beau will slink away disgrazed, leaving her to her chosen mate. This second sort of selection is going on for ever, side by side with the first ; the prettiest, freshest, and most daintily-marked insects being always preferred in the pairing over duller, dingier, or more battered rivals.

It is interesting also to note how the two kinds of seiection run parallel with one another. While the butterflies are poised motionless upon twigs or flowers they are in the greatest danger from birds; but in such positions they close their wings and display only the outer surface, which is imitatively and protectively coloured. The constant picking off of all those which can be distinguished when at rest suffices to keep the protective colours always true. On the other hand, when the insects are on the wing, 
hovering about flowers or rising in the air.to pirouette and gambol with their mates, they run comparatively little risk from the birds. They are too nimble for their pursuers, and they seem fairly secure by their power of doubling as they flit rapidly along from spray to spray. The birds are bad marksmen at a moving target; they cannot double like their prey, and they prefer to aim at their butterflies sitting, as French sportsmen are said to do at partridges. On the other hand, with butterflies as with men, faint heart never won fair lady. If the insects did not venture out into the open to seek their mates and to charm them with their painted pinions, some bolder rivals would carry off the prize, and so leave the cowards unrepresented in future ages. Thus, in the course of generations, a great many butterflies have come to have two sets of colours-the one set attractive for their own kind, and the other set protective against their enemies. The lower sides of the wings are coloured like the leaves or 
twigs on which they sit with folded vans; the upper sides are beautifully dappled with crimson, orange, or metallic sheen, and flaunted boldly in the open sunlight as they flit about to woo their dainty mates. On the other hand, moths, whose habits of folding the wings are exactly reversed, also reverse the system of colouration. Many of them which fly by day are quite as exquisitely decked as any butterflies, especially in the tropics; but as a rule they have the upper surface of the pinions imitative or protective; while the under surface is bright and attractive. The one alone is seen from above, as the insect sits with outspread but depressed wings, close against the ground or the foliage ; the other is turned to the insect's mates, flashing in the sunshine with iridescent hues, as they chase one another fantastically in their airy love-making. Sometimes, however, a single set of colours answers both purposes alike, as I have often noticed with the Jamaican cactus butterfly-a bright yellow 
insect, which sits quite indistinguishable among the yellow flowers of the common wild cactus, while it becomes a very conspicuous creature indeed when it raises itself into the air on its large and brilliant golden wings. Something of the same sort, on a smaller scale, may be observed with our own yellow cabbage-butterflies on the golden bunches of flowering charlock in an English cornfield. 
RED CAMPION AGAIN.

Ecce itcrum Crispinus! Another red campion in the hedgerow, hanging out so temptingly that I cannot refrain from picking it, and, having picked it, from sitting here on the stile between the meadows to pull it to pieces. How ineffably vast and how hopelessly infinite is the study of nature! If a mere dilettante observer like myself - a saunterer who gathers posies and chronicles butterflies by the wayside for pure love of them-were to tell all that even he has noticed in passing of the manners and habits of a single English weed_of its friends and its enemies, its bidden guests and its dreaded 
foes, its attractions and its defences, its little life-history and the wider life-history of its race-he would fill a whole book up with what he knows about that one little neglected flower; and yet he would have found out after all but a small fraction of all that could be known about it, if all were ever knowable. Happy days when an Admirable Crichton or a Pico della Mirandola could offer to dispute de omni scibili with every comer. In our own degenerate times one would hardly like to engage duly to describe the omne scibile of a solitary little red campion. Yet the very sense of this vastness makes it ridiculous presumption for any man to dispose of the red campion altogether at a single sitting. I must stop to look again at my pretty flower, and to decide upon the meaning of at least the most salient points in its structure and arrangement.

The campions are pinks by family, and of course share all the main peculiarities of the pinks generally. But the habit of the family 
as regards its method of fertilisation differs greatly from plant to plant, and has impressed itself markedly upon their forms. There is one great group of pinks which lays itself open to all the small flies and beetles of the world, who come and eat its pollen freely to their hearts' content. Of these, the common chickweed and the white stichwort are familiar examples. Most of them are petty, meanlooking, inconspicuous, weedy plants, because they lay themselves out for mixed small deer of uncertain and undecided tastes, and do not attempt specially to attract the colour-loving bees and butterflies, the asthetic aristocrats of the insect world. Hence their petals are small, ragged, and mostly white, and their calyx consists of five separate spreading pieces. They keep open house, as it were, for all comers without inquiry, displaying their pollen unprotected to whoever wants it, on the chance of a stray grain or two being carried by the insects from head to head. But the campions belong to a higher and 
more specialised department of the pink tribe. They and their ancestors have devoted themselves to bees, butterflies, and other developed flower-haunters, whose long proboscis is peculiarly intended to aid them in extracting the honey from deep tubular blossoms. Thus they have slowly acquired, by long selection, a structure exactly adapted to a surer and less wasteful mode of fertilisation by means of these higher insect allies.

The outer covering of this campion here does not consist of separate green sepals, like those of the stichwort which I have picked for comparison with it: its five pieces are welded together into a swollen bell-shaped tube-a campanular calyx, as the systematists call it. Within the tube, five large pink petals rise on long claws, kept together in shape by the pressure of the calyx. Inside the inner passage formed by the petals lie the pollen-bearing stamens or the ovary with its embryo seeds, each in a separate flower, whereof 'more anon.' Thus the pollen and 
the honey are concealed out of sight of the useless small insects, and they can only be reached by the long proboscis of the bee or the butterfly. To prevent ants, small beetles, and other honey-eating intruders from creeping up the stalk, and so rifling the nectaries without doing any good to the plant in return, the stem of the campion is covered with hairs, and it exudes a sticky, viscid gum, both of which peculiarities aid it in baffling the unwelcome wingless visitors; while the inflated calyx and long tube effectually keep out all flying insects, except the few for whose visits the plant specially lays itself out. Nay, as if so many precautions were not enough, the mouth of the tube, above the stamens, is furthermore obstructed by five little valves or scales, one being attached to the claw of each petal; and these scales can easily be craned over, like tiny walls, by the large and long proboscis of the bces or moths, but not by the little thieving flies against whose incursions the flowers are so anxious to guard 
themselves. Given the red campion, it is easy enough to evolve the white from it ; but who can say how many geological ages have gone to the evolution of that parent form itself from a simple open blossom like the white stichwort?

All these precautions for due cross-fertilisation are now actually in course of being followed up by another precaution yet more efficacious than any. The head of blossom which I hold in my hand, and which I have pulled off in passing, consists wholly of male flowers: every blossom contains stamens only, without any pistils. On the other hand, here in the hedge beside me stands another plant of the same kind whose blossoms are all female : every one of them contains a young capsule only, with the embryo seeds distinctly visible when I cut it open, but without a trace of stamens. This separation of the fructifying elements on different plants is a very recent innovation in the campions, and it marks a very high degree of 
differentiation-one not attained by the vast majority of the most developed plant types. The open pinks, such as chickweed, have stamens and pistils in each flower, and trust to chance for avoiding the evils of self-fertilisation. Even the other campions have the same common arrangement; but the red and white campions are peculiar in the fact that they have suppressed the stamens of some flowers and the pistils of others, thus making separate individuals wholly male or wholly female. Such an arrangement of course makes cross-fertilisation absolutely certain, and gives the species a great advantage in the struggle for life over its less differentiated neighbours. But the recent date of the improvement is shown by its incompleteness; for you may still find some stray campions with perfect stainens and fertile capsules in the same blossom.

Here, as in so many other cases, we catch. modification in the very act. For it is a fatal habit to picture evolution to oneself as a 
closed chapter ; we should think of it rather as a chapter that goes on writing itself continuously for ever. The white campion is even now in course of completing its development from the red; and red and white together are both even now in course of transforming themselves from the hermaphrodite to the separate condition. The naturalist can generally make a shrewd guess at the age of various elements in every plant or animal. He can say, 'This is a peculiarity which must date back before the ancestors of $A$ diverged from the ancestors of $B$, because both of them share in it: this, again, is a peculiarity which dates later than the divergence, because $\mathrm{A}$ possesses it, while $\mathrm{B}$ does not: and this, once more, is a peculiarity which has hardly yet established itself, because it is sometimes found in A to-day, but sometimes it is absent.' In such a manner as this it would not be difficult roughly to reconstruct the whole history of the red campion, if a busy world had leisure to hear it. 
But what centum linguce, what ferrea vox, would ever suffice to reconstruct the whole history of all the plants and animals I can see around me? It is easy enough to catch their episodes vaguely as one examines them ; but to write them all down in definite language is a task of which even science itself may well despair. 
THE broken ground in the warren near Tom Fowler's cottage is full of burrows of every description, from the big badger's-nest by Chimney Rock to the rabbits' holes and tiny shrew-runs that honeycomb the soft mould beside the landslip. Among them are some which I know from the pattering tracks at the mouth or entrance to be the haunts of spiny hedgehogs-the long interval between the prints of fore and hind feet, and the deep toe-nail marks in the damp clay are quite unmistakable; and as we want a tame hedgehog to keep down the cockroaches in our lower premises I have turned out to-day, 
armed with pick and shovel, to unearth and carry off one of these uncanny brutes for my kitchen folk. After a little digging in the bank, using my pick carefully for fear of injuring the poor timid beast, I have got to the round warm nest, a mere hollow in the ground roughly floored with leaves and dry moss and lined on the top with a soft vault of the same materials. And now the creature lies motionless in my shovel, rolled tightly up into a prickly ball, and absolutely unassailable in its spherical suit of sharply pointed spikearmour. No defensive mail could be more effectual or more deterrent. I cannot even lift him up to put him into my basket; I am obliged literally to shovel him in, and then tie down the flap to keep him safely. There I can see him now through the wattles, slowly unrolling himself, and peering about with his blinking, beady black eyes, as if to inquire what Arabian Nights' enchantment has so strangely transferred him against his will to this curious locomotive prison. 
Hedgehogs are really very common animals in England, and yet few people have any idea of their existence among half the hedges and banks in the meadows and copses around them. The little animals lie hidden in their subterranean holes or open nests during the daytime, and only come out in search of slugs, grubs, and beetles at nightfall. Yet they are a precious heritage of our age, for all that ; for they and the few other remaining members of the old insectivorous group form the last survivors of a very early and undeveloped mammalian type, the common ancestors of all our other European quadrupeds, who have diverged from them in various specialised directions. They rank as interesting middle links in that great broken but still traceable chain which connects the higher mammals with their lost and unknown semi-reptilian ancestors. Indeed, if we had never heard of the hedgehogs and their allies before, and if one were now to be brought for the first time by some intrepid explorer from Central Africa 
or the Australian bush, all our biologists would be as delighted with it as they were when the ornithorhynchus and the echidna were discovered and recognised as links between the reptile and the marsupial, or when the supposed extinct fossil genus ceratodus was found alive in the rivers of Queensland, thus connecting the ganoid fishes with the transitional lepidosiren, and through it with the amphibious newts, frogs, and salamanders. The unconscious black-fellow used to devour as barramunda, and the colonist used quietly to pickle as salmon, a marvellous double-lived creature, provided with perfect gills and perfect lungs, for one specimen of which a naturalist would have given his right eye; and so too our own gipsies have been in the habit for ages of baking in a ball of earth the finest surviving representative of the most ancient placental mammalian line. They roll him up (dead, I am glad to say) in a mass of kneaded clay, which they put into the fire whole until it begins to crack; 
and then they turn out the steaming flesh by breaking the ball, while the skin and the spines stick in a body to the hardened lump of earth. Yet the creature which they so unceremoniously devour is actually the eldest scion of the great mammalian stock, whereof all the reigning houses in Europe are, after all, but younger branches.

The insectivores, indeed, as Professor Huxley has often pointed out, occupy the central position among all placental mammals - that is to say, among all mammals higher than the pouched class of opossums and kangaroos. Their brain is very small and undeveloped, and their organs generally are but little specialised. All the other common quadrupeds - the carnivores, the rodents, the ungulates-have certain resemblances towards them which they have not towards one another. This shows that the hedgehogs, moles, and shrews, our representative English insectivores, display as it were an arrest of development-exhibit to us an early 
stage of mammalian life which the other European animals have long passed by. Time was when the ancestors of dogs and deer and sheep and rabbits had risen no higher in the scale of life than these smallbrained and stupid little creatures. But while the other races have for ages outstripped their hedgehog-like ancestors, the hedgehogs themselves have remained always at the same low level of development and intelligence. Such arrests are not uncommon. In the dim past of geological ages, we know that there must have been at some time a primitive forefather of the whole mammalian stock who had some affinities to the true reptiles and still more to the frogs. Of this hypothetical progenitor of hedgehogs and men we have now no trace; but of many subsequent stages we have traces in abundance. The ornithorhynchus and echidna, which are mammals only by courtesy, still preserve for us the intermediate step between this frog-like creature and the true quad- 
rupeds. The kangaroos, wombats, and phalangers show us a still higher link. The insectivores carry us a step further; and from them on to the highest embodiment of all the great types - the cats, the elephants, the buffaloes, the horse, and man-the stages are all easy and gradual.

Why, then, do such intermediate links survive? Why have they not all developed alike? When some primitive insectivores grew into nascent carnivores and nascent ungulates, why did some still remain at the old low insectivorous stage of hedgehogs and moles? The answer is, because their organisation was quite high enough to fit them for the work they had to do in life. They filled a place in the world; and because they filled it they have lived on, while other types, adapted to higher functions, have outstripped them, and taken the upper seats in the hierarchy of animal life. At the same time, there are some important considerations to be borne in mind in endeavouring to understand the reason for 
the survival of such lowly organised groups in the presence of more highly evolved and better-endowed races. In the first place, these straggling survivors are generally found in out-of-the-way places, far from the fierce competition of great continents or of thickly populated districts. Thus the ornithorhynchus and the echidna, the two lowest mammals or quasi-mammals, live in Australia, long isolated from the Asiatic mainland, and with no higher animals of any sort than the kangaroos. The marsupials are similarly confined to the Australian region, with the solitary exception of the opossum. The edentates, another low and early group, including the sloths and armadilloes, belong to South America, for ages a separate island, and only lately invaded by higher types across the newly-raised isthmus of Panama. The lemurs, lowest of the monkey tribe, are almost confined to Madagascar, as are also some other primitive forms. Among the insectivores themselves, the greater number belong to such places as 
Haiti, Mauritius, Java, and the Malay Archipelago generally. Those which live upon the continents, and indeed most of the old types as a whole, are further enabled to drag on their existence somehow by nocturnal, subterranean, or water-haunting habits, as well as by living upon small and innutritious food. Thus the lemurs, hedgehogs, and aye-ayes feed by night only; the ornithorhynchus, oared-shrew, and musk-rat live in the rivers; the mole passes all his time underground ; and the whole set alike burrow or hide away for the best part of their lives, feeding upon insects, like the ant-eater, or upon reptiles and carrion, like the armadillo. Thus, in one way or another, these low forms, by accepting the menial or dishonoured places in the commonwealth of nature, have been enabled to live on, in stealth and quiet, as well as their more highly developed and intelligent relatives.

There is, however, one other consideration which it would be impossible to pass by 
without leaving a very false impression as to these outcasts of animal life. Though they all represent low and little developed types, they are yet as a rule highly specialised representatives of those types. They have survived because they could fill some vacant place or other : and for that place they have become fully specialised. Thus, though the brain, the skeleton, and the other organs of an ornithorhynchus or an echidna are lowly and poor, as judged by a general mammalian standard, yet their external form is very much more specialised than the external form of the primitive mammal could possibly have been. He could not have had the broad duck-bill, the webbed feet, the burrowing and waterhaunting adaptations of the ornithorhynchus on the one hand, nor the spiny coat and curious digging paws of the echidna on the other. So with the insectivores. The hedgehog represents the primitive insectivorous type, plus the familiar sharp prickles, which exactly recall those of the echidna: 
and indeed the tenrec of Mauritius is a hedgehog in an early stage of evolution, with the spines only half developed. The mole in like manner represents the same primitive insectivorous type, plus the peculiar powerful shovel hands, the hidden eye, the covered ear, and the close fur, which fit it so well for its underground life. It is just the same with the scaly armour of the armadillo, and the long snout or brush-clad hind feet of the ant-eater. In every case these low forms have only survived through a singular combination of favouring circumstances-isolated position, unusual habits, special protective armour or concealment, immense adaptation to peculiar needs. What can be more interesting than to notice the independent occurrence of the very same device of spiny mail in two creatures so unlike in structure yet so like in habit as the echidna and the hedgehog? But if I go on preaching in this way I shall never carry my hedgehog home. 
A steep pull up the hillside, through the lanes cut for rabbit-shooting among the gorse and bracken, leads us at last to the old prehistoric earthwork or 'castle' which crowns the top of Musbury Hill. The glorious view from the breezy summit rewards one well for the trouble of climbing. In the foreground the furze or heather on the slopes is quaintly divided into formal squares of golden blossom by the little parallel avenues, down which innumerable white tails of rabbits disappear twinkling into the burrows at every step we take. Near the foot of the hill, just before reaching the valley, an apple orchard stands 
thick with pinky bloom, a good promise for the cider season; and the trunks, blown all one way by the wind, are almost hidden from sight by the luxuriance of their lovely burden. Beyond, again, the broad alluvial level stretches away to westward, with the Axe meandering in S's through its midst; while in the distance the russet ploughed fields among the meadows on the opposite range betray the red triassic soil of Devonshire. Looking along the river's course, a glimpse of sea closes the vista towards Seaton-a mere blue bay, hemmed in between the red cliff of Axmouth on the one hand and the taller white chalk bluffs of Beer Head and Branscombe on the other. But it is not wholly for the sake of the view that I have toiled up the abrupt gradient of Musbury Castle this clear May morning. Among the flinty piles of the old earthworks-once the border fortress of the Durotriges against their Damnonian foes-a little flower grows from year to year, which is found nowhere else in 
the neighbourhood for many miles; and it is to get a few sprigs of this rare flower that I have come up here to-day, as is my yearly wont. I have just pulled it up, root and all, out of a chink in the rubble this moment; and I shall take it home in my little tin case by-and-by to examine it at my leisure hereafter, and make quite sure about some odd small points in its mode of flowering whose meaning and purpose I have not yet been able thoroughly to understand.

Meanwhile, what a curious fact it is, this regular recurrence of the same plants and animals in the same situations from season to season! When once you have learned a little district thoroughly, it is wonderful how constant the geographical distribution of its fauna and flora always remains. In one marshy spot hereabout, and one alone, I find, summer after summer, the sundew and the bog asphodel. In one lane, from time immemorial, the green hellebore has flowered, and nowhere else. On the cliffs to eastward, 
the wood-pigeons always build their nest; on those to the west, I have never roused a single bird. There are certain pools in the little stream which rises on the castle where a certain fixed number of smallish trout are always found; but in the branch that comes down from the green-sand opposite only stickleback and miller's-thumbs are to be caught. In fact, every part of nature is a constant equilibrium: there are certain species fitted for certain places, and in those places only they exist.

This balance of life is very seldom interfered with in any way. Now and then new obtrusive species push their way in ; now and then fresh varieties develop and slowly oust the older forms; but on the whole the intricate interdependence of all parts on one another is so great that very little change ever takes place. As in the village below there is always a baker, and a butcher, and a doctor, and a parson, and a grave-digger, each fulfilling his swn function, and each dependent upon the 
rest for support, so in the broader world of plant and animal life upon the castle here there is always a fairly fixed number of species and individuals, all fitting in together into the marvellously complicated scheme of checks and counter-checks, of mutual services and reciprocal needs. There are always just enough bees to fertilise the heather, and just enough heather to feed the bees, hedgehogs to keep down the wire-worms, and dragonflies to chase the gnats. In every bit of boggy ground you find boggy plants; and above them you find bog-haunting insects, on which the waterside birds perpetually prey. Wherever there is a chance for a plant or animal to make a living for itself, there you find some creature living and adapted to its place. No nook in nature is too small or inconsiderable to be occupied. Countless seeds and eggs and germs are being scattered broadcast over the whole face of the earth every day and all day long; and those of them which find their fitting place live and 
thrive, while those of them which fall on the wrong ground die out and disappear at once.

In such a complex balance of life as this it might at first sight seem as though no new forms could ever be evolved. Where the conditions to be complied with are so numerous, where the interaction is so allembracing, surely it must be hard enough just to keep up the ordinary requirements of each species, without ever rising to higher and still higher complications again. But if we look a little closer into the problem, we shall see that this very complexity itself produces the necessity for further advance. Every plant and every animal must succeed, not only partially, but always and all along the line. The seed must escape the attacks of birds or animals, for if it is once eaten up it can never grow to be a plant at all. The young shoot must escape the grubs and locusts; the flower must open and secure its fertilisation; the fruit must set and ripen its seeds; the seed again must be dispersed and 
reach its proper soil and position. Every plant which fails, no matter how little, in any one of these particulars, is utterly lost. Its chance of producing posterity is wholly gone from it. And the same is true of animals. The butterfly, for example, must find food as a caterpillar, and must escape the eyes of birds ; it must hide itself away as a chrysalis ; it must make itself proof against frosts and rains; it must hit upon sunny weather in its full-fledged winged form; it must find, woo, charm, and secure its mate; it must lay its eggs on the proper plants, and in a safe position. Thus every existing individual of every species is the descendant of countless ancestors on each side, every one of whom must necessarily have fulfilled all the complex conditions of existence at every moment of their lives. If they had not done so, it would not be here en évidence to answer for their success.

However, as all individuals are liable to vary a little individually - to be lighter or 
darker, larger or smaller, longer in this limb and shorter in that, than one another-it must follow that each individual must be slightly better or worse adapted for surviving in certain special circumstances than some other. Such petty differences are for ever being produced, and the better are constantly, on the average, living down the worse, while the worse are being constantly weeded out. If at any moment we look at the world as a whole, we see apparent balance, nay rather real temporary balance; every part fits in to every other with absolute adaptation. But if we compare widely different times we see that the balance is always altering, that types change indefinitely from age to age. Each plant and each animal fulfils all the necessary conditions of existence every day of its life, or else ceases to exist, the survivors being always those who have succeeded in fulfilling them; but then the conditions are always slightly changing, and so the survivors from time to time are slightly different. Every 
increase of speed in the pursuer is followed by an increase of speed in the pursued, since only the swiftest will now escape; every sharp-toothed squirrel opens still harder and harder nuts, and thus leaves the very hardest alone to produce future trees. The squirrel survives because it can crack nuts which other squirrels must refuse; the nut survives because it can baffle the squirrel which can crack so many other nuts. 


\section{VIII.}

A BIG FOSSIL BONE.

THE cliff to eastward of the village consists of soft blue lias strata, interspersed with harder layers of concreted limestone; and both deposits are worked by the quarrymen for different purposes. The soft sticky clay of the banded belts is used in making blue lias cement at the little mill beside the harbour-our one solitary manufacturing industry-while the intermediate hard layers are burnt for quicklime in the village kilns. This morning, a message from one of the navvies, who knows my taste for antiquities, brought me up here in hot haste from the breakfast table, for fear the rival collector 
should be beforehand with me in securing a splendid prize. He had found, he said, a lot of 'verterberries' - that is our local word for vertebræ-and also what he took to be a flint implement. One can never trust the scientific diagnosis of a quarryman, so I was not quite sure whether he had really hit upon a big saurian in the secondary lias, or upon some mammalian remains in the quaternary gravel which caps the cliff, and which the workmen have to clear away in the course of their excavations. Fortunately for me, it turned out to be the latter : for I do not busy myself much about 'dragons,' as our navvies call the great saw-toothed saurians, but I am always interested in a stone instrument, or anything else which bears directly upon the early history of mankind. The bones proved to be three fragments of a mammoth skeleton; and close beside them in the gravel lay the sharp flint knife in situ, with which perhaps some palæolithic hunter had scraped the bones of his huge prey a hundred thou- 
sand years ago, when the little river still flowed at this higher level, thirty yards above the bed of its existing channel. I have pocketed the flint after a little commercial transaction with the navvy offhand: and now I am mounting guard over the mammoth bones, waiting till a relay of workmen arrives from the village below to dig them all out for me carefully as they stand.

It is common enough to hear visitors at a geological museum say to one another, - Ah, everything used to be so much bigger in those days'-the exact period to which they thus refer being no doubt the cosmical equivalent of that familiar historical epoch, the olden time. Looking about them at the big fossils which form the most striking features of the exhibition, they picture to themselves a world where the sea swarmed with gigantic enaliosaurians and huge cetaceans, where the land was covered with deinotheria and mastodons, where all the 
birds were moas, all the lizards were crocodiles, and all the snails were monstrous ammonites. Everywhere they seem to find in fossil forms a bigger animal of each kind than any now existing. They see here an enormous Irish elk, there an immense extinct sloth, yonder a vast prototype of the little modern armadillo, and somewhere else a turtle ten times as big as the greatest living member of the tortoise group. They forget that the huge saurians were secondary animals, while the deinotherium was tertiary, the mammoth quaternary, and the moa all but modern. They forget that the age of the great ammonites was almost over before the age of the great lizards set in. They forget that the glyptodon lived in South America, while the big elk lived in Ireland. By that kind of false historical perspective which throws all the distant past into a single line, they roll together millions and millions of years; and so they get a distorted geological picture, which really quite reverses the actual 
facts as to the relative size of animals in the past and the present.

As a matter of fact, it seems probable that our actual fauna and flora are on the whole not only quite as big as any previous ones, but even a great deal bigger. If we take single instances, no known extinct animal was as large as some of our modern whales; if we look at the ensemble of our existing species, no known period comprised so many large forms as we can show at the present day in our three or four great cetaceans, our two elephants, our hippopotamus, our rhinoceros, our bisons, our giraffe, our walrus, and our horses. These would probably form a total assemblage of larger average size than any previous epoch could produce. Similarly, in almost every special class, we could apparently show larger species at the present day than any which we know to have existed in fossil forms. Our whale is the biggest known mammal; our gigantic salamander is the biggest known amphibian; 
probably our sun-fish, our tunnies, our sharks, and our devil-fish are each in their way larger than almost any previous fishes-one living shark actually attaining a length of forty feet. No fossil bivalve molluscs to my knowledge are as big as the common Mediterranean pinna, or as that giant clam, the tridacna, whose shell is so commonly used as a basin for fountains. In fact, there are only two important groups, the birds and the reptiles, in which extinct species were much larger than existing ones; and in these two groups the decrease is evidently due to the later supremacy of the mammalian type.

Similarly, if we take many comparatively modern lines of descent, we shall find that the horses, the deer, the elephants, and several other now dominant groups of animals have been steadily increasing in size from the earliest epoch of their appearance to the recent period. And among the great extinct creatures, some-like the moa and the dodo -have only quite recently been killed off; 
others-like the Irish elk and the mammoth -belong to the very latest geological period; and yet others, though of somewhat higher antiquity-like the animals of the Paris basin -have left representatives nearly, if not quite, as big as themselves. The teeth of what seems to have been the biggest known fisha prodigious shark-are dredged up among the modern ooze of the Pacific; and though no individuals quite large enough to have owned them have ever been observed, yet people who believe in the sea-serpent may well expect one to turn up in the flesh at some future period, while even more sceptical persons must still admit that they have become extinct at a very late date.

The explanation of the existence and extinction of extremely large animals in each group seems to be this. As a whole, evolution appears to tend towards an increase of size in some members at least of every class. But this increase is most noticeable among members of what is, for the time being, the 
dominant class ; and, when another class outstrips it in development, the new dominant kinds are apt to live down the bigger species among their predecessors. Thus, in the very earliest times, the molluscs were apparently the dominant class; and very big cuttlefish and other cephalopods were frequentthough none of them, perhaps, were quite so big as our own gigantic squids. At a later date, the reptiles were developed, and grew to be the leading race on earth; and during that period the bigger saurians attained to extremely large dimensions. Ever since the opening of the tertiary period, however, the mammals have become the forefront of the animal series, and big mammals have everywhere replaced big reptiles. But there were some few insulated spots where mammals did not penetrate for a long time, and here birds were the leading class. In such cases terrestrial birds grew to be very large indeed.

On this simple principle we can account for almost all the big creatures now existing 
upon earth. In the great continents they are almost all dominant mammals; for example, the elephant, rhinoceros, hippopotamus, giraffe, and bison. Wherever we get large species of lower mammals or of the inferior classes, they are invariably found either on insulated lands or on lands but recently united to the continents. Thus, the great fossil sloths, armadillos, and other edentates belong to the insular fauna of South America, where no higher mammals existed; as soon as the mammalian types of the northern continent began to make their way across the quite modern Isthmus of Panama, all the bigger native forms became extinct. Just in the same way, Australia still possesses a very large marsupial in the great kangaroo; but if the Australian region had ever been joined to Asia, the Asiatic carnivores would soon have exterminated this stupid and defenceless herbivore. So, too, the moa was developed in New Zealand, where there were no mammals at all, and where the 
apteryx is still the highest native animal, now that the moa has been exterminated by man. In like manner, the ostriches and rheas, the cassowaries and emus, and all the other big struthious birds belong either to the islands of the Australian and Malay group, where they have but little mammalian competition, and that of a low grade, or to South Africa and South America, both of which were long equally insulated, and where most of the fauna is still of a very inferior type. Similarly with reptiles: the big saurians are all dead except in the case of the crocodiles and alligators which haunt fresh waters alone; and fresh waters, we know, are almost as insular in their way as islands themselves. The Galapagos archipelago has for its highest inhabitant a monstrous lizard. Among amphibians, again, the gigantic salamander belongs to Japan.

On the other hand, the two great continents which developed the higher mammalian fauna-Europe and Asia in the east, 
North America in the west-have no very large birds, no very large terrestrial reptiles, no very large amphibians; and their lower mammals are all small and skulking species -mere rats, hedgehogs, shrews, and moles, instead of big sloths, kangaroos, or megatheria. In the oceans, where mammals are at some disadvantage, and where they have not yet firmly established themselves, big fish still abound. Nevertheless, even here, the whales, porpoises, walruses, seals, manatees, and other aquatic mammals are pushing them hard; and we know that the sharks and rays, the monsters of their kind, as well as many other big tribes of fish, are now in their decadence. Thus it would seem that everywhere some animals of the dominant types are the largest, and that mammals, therefore, now tend all over the world to replace the large members of inferior groups. 
THIs pretty little blue flower, growing so abundantly beside the footpath, is called in English speedwell, and in botanical Latin veronica. Thereby hangs a sufficiently pretty legendary tale. Everybody knows how the napkin with which a compassionate maiden wiped the face of Christ on the morning of the crucifixion bore ever after the imprint of the divine features. The miraculous portrait thus preserved as the one genuine picture of Our Lord was known in a mongrel Greek and Latin phrase as the vera icon, the true eikôn or image of the martyred Saviour. By a natural transposition of sound and sense, 
the unknown maiden was popularly canonised as St. Veronica, just as the real blood of Christ, the Sangre Real or Sang Réel, preserved by Joseph of Arimathea, became the Saint Gréal and the Holy Grail of mediæval legends. At some later period, by a pretty conceit, some poetical botanist or other-I think it was Tournefort, though I don't know whether he invented the name himself or only borrowed it from the early herbalists-transferred the title of veronica to this lovely little blue blossom, because it seemed to him exactly to mirror in its delicate hue the deep azure colour of the sky above. It was the vera icon of the open heaven, and so he called it, too, veronica. The conceit is far-fetched, no doubt; but it is a pleasant one to me ; and I can never see the first speedwells opening their familiar blue flowers in the spring-time without feeling that the legend throws an added charm for my mind around their simple native prettiness.

Our thoughts about nature are often too 
largely interwoven with hard technicalities concerning rotate corollas and pedicellate racemes; and I for my part am not ashamed to confess that I like sometimes to see the dry light of science diversified with some more fallacious scintillations of the litere humaniores or even with some will-o'-the-wisp of pure poetical imagination. After all, these things too are themselves matter for the highest science; and that kind of scientific man who cannot recognise their use and interest is himself as yet but a one-sided creature, a chemical or biological Gradgrind, still spelling away blunderingly at the weak and beggarly elements of knowledge, instead of skimming the great book of nature easily through, with a free glance from end to end. Surely there are more things in heaven and earth than are dreamt of in Gradgrind's philosophy.

For example, there is the beauty of the veronica. Even if the Gradgrinds do not see it, you and I do; and it is clearly the business of science to explain this difference 
between us and Gradgrind, as well as to explain why we have the sense of beauty at all. There are two kinds of one-sidedness which the real man of science will do well to avoid. Thoreau, who loved nature as few men have loved it, nevertheless sneered at geology as a lot of old broken shells : that was the one-sidedness of the poetical and artistic temperament. He thought he was showing his own superiority of mind when he was really showing only his narrowness of view. On the other hand, Gradgrind and Dryasdust sneer at the beauty of the veronica; that is the one-sidedness of the practical, technical, and scientific temperament. The true man of scierce will reconcile the two. He will see no incompatibility between loving the birds and beasts as well as Thoreau, and yet taking an interest in the old broken shells as well as Lyell or Murchison; between knowing all about the conduplicate cotyledons with Dryasdust, and admiring the autumn fields with Millet or 
with Ruskin. The two stamens and the united petals of the veronica are facts which demand explanation in one way; the blue colour and the touching prettiness of the same veronica are facts which equally demand explanation in another way: and I for my part can see no reason why the one set of facts should not be just as worthy of scientific examination as the other.

Luckily for us, we have now at last got a philosophy of life which enables us, as it seems to me, to explain both on very similar principles. The tubular shape of the speedwell's corolla and the irregularity of its stamens, as well as the peculiar one-sidedness of its petals, are all due to the necessities of its fertilisation by insects. In that way, and in no other, it secures the safe deposit of its pollen on the head of the bee or the beetle, and its further safe conveyance to the pistil of some neighbouring blossom. For just the same reason it has bright blue petals to attract the eyes of the insect ; and those petals 
are streaked with dainty darker or lighter lines, which guide the friendly visitor straight to the honey-glands. That, put briefly, is why the veronica is blue and delicately veined.

The reason why we consider these colours, meant to attract the insect, as pretty, seems to me equally obvious. We are the descendants of ancient arboreal ancestors, who themselves sought their food among bright orange and blue and crimson fruits in tropical forests; and those fruits were specially coloured to allure their eyes, just as the speedwells and primroses and buttercupsare specially coloured to allure the eyes of bee or butterfly. And further, as the eyes of the bees are so developed that these colours attract them, the eyes of our pre-human ancestors must have been so developed as to be attracted by the similar colours of oranges and mangoes, and tertiary plums or peaches. Flowers and fruits alike depend upon animals for fertilisation or dispersion; and alike possess 
the same enticements of sweet juices, fragrant scents, and bright colours. Hence it seems natural to conclude that the senses of animals have been evolved in strict correlation with such stimulants, and that the thrill of pleasure which we now derive from beautiful colours is in some degree $a$ vague and persistent echo of feelings long since experienced by our frugivorous ancestors.

And shall we therefore say with the writer in last week's Nature, which I have brought out in my pocket, "We are landed at the rather humiliating conclusion that a sense of the beautiful, and an admiration for the forms and colours of nature, is only a strongly developed instinct inherited from the lower animals ?' Oh no, surely far otherwise. We have not so learned Darwin and Spencer. As just now I read the writer's words, lying here in the sunshine on the bank, I picked this blue speedwell, and gazed closely at it, and I saw denial looking at me from every line on its face. We might as well say that 
the artistic sense of a Burne Jones or a Rossetti was a survival from the artistic sense of the cave-men who etched reindeers in the Périgord grottoes, or that the mechanical genius of a Watt or an Edison was an instinct inherited from the black-fellows who chipped flints ages ago beside the Somme at St. Acheul. Darwinism does not degrade our race-it elevates it. For the fall of man it substitutes the rise of man : for a hopelessly degraded lapse from an imaginary Paradise in the past it substitutes a hopeful progress towards a perfectible and realisable Paradise in the future.

The love for the blue colour in the veronica is doubtless due in its inception to the primitive love for colour common to all frugivorous races. But it is not only that. If it were a mere survival it would be weaker in us than in the monkeys; whereas it is, as a matter of fact, infinitely stronger. We all of us-yes, including even Gradgrind himself love the little blue veronica with a love of 
which no lower animal is capable. We have gone on increasing and widening our love for colour - we have employed it first for personal decoration, in flowers, feathers, gems, and pigment; then for the decoration of our houses and belongings; then for painting proper and true art. Thus at last the mere beauty of colour by itself, apart from other emotional associations, has become far more potent with us, and especially with civilised man, than with our early progenitors or with our four-handed cousins. We can admire sunsets and sunrises at which they would gaze in stolid indifference. We can admire autumn hues, and distant hills, and countless effects of cloud or light on sea and sky and landscape. And to all these we add a thousand higher elements of the sense of beauty. We feel at once that the speedwell has symmetry of a beautiful sort, which we have learned to appreciate more than any other creatures in the slow growth of human products, from the stone hatchet to Brussels 
lace and Henri II. pottery, from the circular hut to Salisbury and Chartres. We feel, also, the beauty of its home associations, of its connected legendary lore, of its old English name, of its domestic familiarity. We feel the reflection upon it of much poetical fancy and dainty conceit. All these things go to make up our sense of beauty when we look at a speedwell, just as much as the blue colour and the primitive instinct of our semihuman progenitors. Do not let us shut our eyes, like Mr. Ruskin, to the elementary facts disclosed by biology; but do not let us, on the other hand, try to resolve our whole complex nature into quadrumanous elements. Man is none the less man because we believe that his very remote ancestor was a sort of distant cousin to the gorilla. We to-day are none the more gorillas for all that. 


\section{$\mathrm{X}$.}

GUELDER ROSE.

Coming out here into the alder copse this bright breezy summer evening, in search of the sweet-scented butterfly orchids which grow so abundantly in the marshy spots beside the bourne, I have not only gathered a thick handful of those quaint green-tipped spiky flowers themselves, but have also lighted unexpectedly upon the first full-blown guelder rose of the season. The bush hangs out of the hedge which severs the copse from the Four Acre; and my eye was attracted a hundred yards off by the great bunches of snow-white blossom, drooping in massive trusses from the long sprays that outgrow the 
shorter and stiffer branches of the over-blown hawthorns. Guelder roses are by no means rare flowers, yet I always like to pick a piece or two, because of the curious peculiarity which causes them to be cultivated so much in our shrubberies. Not that this real woodland bush-flower has any close resemblance to the round balls of distorted blossoms that our gardeners and florists have been at so much pains to produce for the delectation of tasteless patrons. In this its native state the guelder rose has a bunch of small white, or rather cream-coloured flowers, for the most part a good deal like those of the elder; and, indeed, the very name is said to be a mere philological blunder for elder-rose, and to have no real connection with Guelderland in any way. Still more closely do the little cream-coloured flowers resemble the blossoms of the wayfaring-tree, a member of the same genus, whose mealy leaves and little blue-black berries are familiar objects towards the close of autumn in every tangled overgrown hedge- 
row. The guelder rose differs, however, from the wayfaring-tree in one conspicuous particular. It has a row of large snow-white flowers on the outside of each bunch, at least twenty times as big as the central ones. They look almost as if they were the blossoms of some other and larger plant, deftly arranged or pinned by some mischievous boy around a bunch of elder blossom, so as to hoax the unwary botanist with a cunning deception. But they are real component elements of the flower-head for all that; and it is these self-same odd, overgrown outer flowers which make the guelder rose so interesting a plant in the eyes of the evolutionary biologist.

Looking close at the small central florets one can see at a glance that each has a little tubular corolla of five united petals, with stamens and pistil in the centre, enclosing the germ of a future berry. But the big expanded outer blossoms are built on quite a different plan. They consist entirely of a large 
flattened corolla with four or five roundedged lobes, milk-white instead of creamcoloured, and measuring near an inch across, instead of being hardly larger than a barleycorn. Moreover, most significant of all, they have no stamens, no pistil, and no ovary containing an embryo fruit. They are barren blossoms, without any other object in life than that of bare display. What, then, is the good of them?

Well, their purpose is, no doubt, to add extra attractiveness to the bunches of which they form part. All plants that depend upon insects for their fertilisation are compelled to make a great show in order to lure the insects into paying them proper attention. In the guelder rose a few outer flowers of each bunch are sacrificed to this particular purpose. They are specialised for the function of attraction, as the philosophical botanists would say. This is, indeed, a phenomenon which occurs often enough in many plants, though in few so conspicuously as in the 
guelder rose. In daisies and sunflowers, the outer florets of each head have their petals prolonged into pink-tipped or golden rays, which give the compound bunch much the appearance of a single blossom. In cow-parsnip and most other umbellates the two outer petals of all the external flowers grow much bigger than their three inner petals, so as greatly to increase the total conspicuousness of the whole bunch. Whenever the separate blossoms of a plant have grown so small as to be individually little attractive, they will clearly gain an advantage by detailing some of their number to do special duty as advertisements. But it seems difficult at first sight to see how natural selection can bring about such a result. Mr. Herbert Spencer has pointed out the way out of this difficulty.

If you look at a cow-parsnip, you will see that the crowded central flowers of each head are very small, with cramped petals, because they have no room to expand without crushing one another; but the freer external 
flowers are much larger, with broader petals, especially $y_{\text {, }}$ on the outer edge, because they have plenty of room in which to spread, and plenty of light and air on which to feed. Thus, in all crowded trusses of blossom, the outer flowers tend as a rule to grow larger and more showy than the inner ones; and if this natural tendency happens to aid the plant by giving it an extra chance of insect fertilisation, it will be increased and specialised by constant selection of those individuals which best display it. Our gardeners carry the process one step further; for they artificially select such guelder roses as have the largest number of barren flowers in each head, until at last they produce a carefully cultivated monstrosity with all the flowers barren and broad-petalled, so as to form a great white fluffy ball. Such a monstrous variety could never be perpetuated in a state of nature, because it produces no seed: it can only be propagated by slips and cuttings. But our florists are fond of these distorted forms, their 
only object being to produce a mass of coloured surface, irrespective of use to the plant. So in double daisies they turn the inner fertile flowers into barren rays; in the dahlia they cultivate out the central florets, and make the others mere useless tubular blossoms; and in roses they degrade the stamens into shapeless and supernumerary petals. Such artificial flowers are never beautiful to a botanical eye, because they lack symmetry and order. When once you have learnt to understand and admire the simple and effective plan upon which all flower architecture is based, these distorted and monstrous blossoms have no more attraction for your eye than the calf with five legs or the two-headed nightingale has for any cultivated taste.

Here is another curious point about the guelder rose. If I cut open one of the very young flower-buds, and look at it carefully with my powerful little pocket lens, I can see that in this early stage it has threc cells in 
the undeveloped fruit, whereas the ripe berry has only one, with a single seed. Even in the full-blown flowers here two of the cells have atrophied, though there are still three little stigmas or sensitive surfaces for the pollen, as though the plant did not know its own mind, and rather expected to have three seeds in each berry, instead of one. This curious indecision is doubtless due to a certain historical fact in the ancestry of the guelder rose. Once upon a time, no doubt, the progenitors of the guelder rose had small dry capsules instead of berries, with a number of seeds in each cell. Such a plant as the red campion still retains this haibit; and, therefore, as the seeds merely fall out loose upon the ground, it is necessary to produce a great number of them, in order to secure a fair chance that one at least shall fall upon a fitting spot for its germination. But in some plants the seed-covering grows soft and succulent, becoming what in ordinary parlance we call a fruit or berry. Then a bird swallows 
the entire vessel, seed and all; digests the pulpy covering; and rejects the hard seed in circumstances admirably adapted for its growth. Plants of this sort, therefore, lay themselves out to allure the dispersing birds, and accordingly fill their fruits with sweet juices and bright colouring, just as they render their flowers attractive with honey and surround them with brilliant petals to allure the fertilising insects. Moreover, they need not now produce much more than one seed in each fruit, because the seeds have so much a better chance of growing up than they used to have. Hence most berries contain very few seeds, often only one, and in many cases the numerous cells of the dry ancestral capsule get aborted in an early stage, because they are no longer needed by the juicy modern fruit. Almost all the honeysuckle tribe (to which, though you would hardly think it, the guelder rose belongs) have succulent fruits; and their seeds are solitary, or at least very few in each cell. So that the three cells of 
these very young flowers keep up the memory of a time when the guelder rose had not as yet acquired its berry, but was obliged to produce large numbers of small dry seeds in a three-celled capsule.

There are two more small matters connected with this bush which one can hardly afford to overlook. The first is that while the flowers are white, the berries are blackish red, and those of the nearly allied wayfaring-tree are dark purple. Now, white is a common colour for flowers, but very rare in fruits; while black or dark blie and purple are common colours for fruits, but very rare in flowers. The plant is obliged to use one set of hues to attract the proper insects, and another set to attract the proper birds; for we now know that each species of insect and of bird has a very decided taste of its own in the matter of chromatics. The second point is this : the leaves of the guelder rose have a number of small swollen glands all along the stalk, and a fringe of ragged-looking leaf-like 
appendages where they join the branch. These are very marked and obviously useful structures : what is their meaning? That I do not know. I merely mention them because their object seems at present insoluble. One might say the same thing about a hundred other points in every plant or animal one picks up in a country stroll. The descriptions of naturalists are apt to make one suppose that we know all about them. In reality, only a few small parts of their mechanism are yet even partially understood. The very idea of explaining the origin of organic structure genetically is still a novel one. We have only just begun to dig at the vast mine ; and all we can do as yet is to unearth a solitary little nugget or two and parade them before the world. The labour of the old-fashioned naturalists has collected an enormous mass of facts as to form and structure; but as to use and function we have still almost all the work to do. 


\section{XI.}

THE HERON'S HAUNT.

Most of the fields on the country side are now laid up for hay, or down in tall haulming corn ; and so I am driven from my accustomed botanising grounds on the open and compelled to take refuge in the wild bosky moorland back of Hole Common. Here, on the edge of the copse, the river widens to a considerable pool, and coming upon it softly through the wood from behind-the boggy, mosscovered ground masking and muffling my footfall-I have surprised a great, graceful ash-and-white heron, standing all unconscious on the shallow bottom, in the very act of angling for minnows. The heron is a some- 
what rare bird among the more cultivated parts of England; but just hereabouts we get a sight of one not infrequently, for they still breed in a few tall ash trees at Chilcombe Park, where the lords of the manor in mediceval times long preserved a regular heronry to provide sport for their hawking. There is no English bird, not even the swan, so perfectly and absolutely graceful as the heron. I am leaning now breathless and noiseless against the gate, taking a good look at him, as he stands half-knee deep on the oozy bottom, with his long neck arched over the water, and his keen, purple eye fixed eagerly upon the fish below. Though I am still twenty yards from where he poises lightly on his stilted legs, I can see distinctly his long pendent snow-white breast feathers, his crest of waving black plumes, falling loosely backward over the ash-grey neck, and even the bright red skin of his bare legs just below the feathered thighs. I dare hardly move nearer to get a closer view of his beautiful 
plumage; and still I will try. I push very quietly through the gate, but not quite quietly enough for the heron. One moment he raises his curved neck and poises his head a little on one side to listen for the direction of the rustling; then he catches a glimpse of me as I try to draw back silently behind a clump of flags and nettles; and in a moment his long legs give him a good spring from the bottom, his big wings spread with a sudden flap skywards, and almost before I can note what is happening he is off and away to leeward, making in a bee-line for the high trees that fringe the artificial water in Chilcombe Hollow.

All these wading birds-the herons, the cranes, the bitterns, the snipes, and the plovers-are almost necessarily, by the very nature of their typical conformation, beautiful and graceful in form. Their tall, slender legs, which they require for wading, their comparatively light and well-poised bodies, their long, curved, quickly-darting necks and sharp beaks, 
which they need in order to secure their rapidswimming prey-all these things make the waders, almost in spite of themselves, handsome and shapely birds. Their feet, it is true, are generally rather large and sprawling, with long, widespread toes, so as to distribute their weight on the snow-shoe principle, and prevent them from sinking in the deep soft mud on which they tread; but then we seldom see the feet, because the birds, when we catch a close view of them at all, are almost always either on stilts in the water, or flying with their legs tucked behind them, after their pretty rudder-like fashion. I have often wondered whether it is this general beauty of form in the waders which has turned their æsthetic tastes, apparently, into such a sculpturesque line. Certainly, it is very noteworthy that wherever among this particular order of birds we get clear evidence of ornamental devices, such as Mr. Darwin sets down to long-exerted selective preferences in the choice of mates, the ornaments are almost 
always those of form rather than those of colour.

The waders, I sometimes fancy, only care for beauty of shape, not for beauty of tint. As I stood looking at the heron here just now, the same old idea seemed to force itself more clearly than ever upon my mind. The decorative adjuncts - the curving tufted crest on the head, the pendent silvery gorget on the neck, the long ornamental quills of the pinions-all look exactly as if they were deliberately intended to emphasise and heighten the natural gracefulness of the heron's form. May it not be, I ask myself, that these bircls, seeing one another's statuesque shape from generation to generation, have that shape thus hereditarily implanted upon the nervous system of the species, in connection with all their ideas of mating and of love, just as the human form is hereditarily associated with all our deepest emotions, so that Miranda falling in love at first sight with Ferdinand is not a mere poetical fiction, but the true illustration 
of a psychological fact? And as on each of our minds and brains the picture of the beautiful human figure is, as it were, antecedently engraved, may not the ancestral type be similarly engraved on the minds and brains of the wading birds? If so, would it not be natural to conclude that these birds, having thus a very graceful form as their generic standard of taste, a graceful form with little richness of colouring, would naturally choose as the loveliest among their mates, not those which showed any tendency to more brighthued plumage (which indeed might be fatal to their safety, by betraying them to their enemies the falcons and eagles), but those which most fully embodied and carried furthest the ideal specific gracefulness of the wading type? In some such way, it seems to me, the herons, and cranes, and storks, and marabous may have acquired their very distinct and noticeable crests or lappets.

Forestine flower-feeders and fruit-eaters, especially in the tropics, are almost always 
brightly coloured. Their chromatic taste seems to get quickened in their daily search for food among the beautiful blossoms and brilliant fruits of southern woodlands. Thus the humming-birds, the sun-birds, and the brush-tongued lories, three very dissimilar groups of birds so far as descent is concerned, all alike feed upon the honey and the insects which they extract from the large tubular bells of tropical flowers; and all alike are noticeable for their intense metallic lustre or pure tones of colour. 'Again, the parrots, the toucans, the birds of paradise, and many other of the more beautiful exotic specics, are fruit-eaters, and reflect their inherited tastes in their own gaudy plumage. But the waders have no such special reasons for acquiring a love for bright hues. Hence their æesthetic feeling seems rather to have taken a turn towards the further development of their own graceful forms. Even the plainest wading birds have a certain natural elegance of shape which supplies a primitive 
basis for æsthetic selection to work upon. Mr. Darwin has shown that birds in early times were less brightly coloured, and less decorated than their modern descendants. He might also have added that the most central and least specialised modern members of each great group are similarly wanting in ornamental adjuncts. They represent the earliest surviving forms of those into which the original type has split up ; they have departed least from the primitive organisation of the class to which they belong. Conversely, the most highly developed and specialised members of each group are those among which we most often find extremely marked æsthetic decoration. The dominant creatures of every class can afford to pay most attention to beauty; the less advanced and more skulking kinds are glad enough to eke out a precarious livelihood for themselves as best they may, and so run rather towards protective colouring and unobtrusive forms than towards conspicuous ornamentation. 
Among the waders this principle is very fully exemplified. The most central and least specially developed of the group are its smaller members, such as the plover, the woodcock, the snipe, and the sandpipers, all of which are only half-developed waders, without the full characteristic structure or correlated habits of the class. They live by the side of small streams; they roam a good deal on land in the fields; and they have only moderately long legs and necks. Moreover, they are coloured protectively to. resemble the dry grass or sand on which they hop about, and so to deceive the eyes of hawks. Many of them are more or less nocturnal, and all of them are timid, skulking birds. They seem to be half-way, so to speak, on the road from the central undifferentiated group of birds, represented by the larks and sparrows, to the thorough-going waders, represented by the storks, cranes, and herons. Not one of them has a single patch of bright colour, a single ornamental 
plume, crest, or lappet. Close-fitting, inconspicuous plumage is their common characteristic.

On the other hand, those waders which have taken to a thoroughly wading life have consequently developed by natural selection longer legs and necks, and more specially adapted feet and beaks. Some of them are even webfooted, and others boatbilled. These larger, better developed, and more dominant birds are generally distinguished by æsthetic decoration. Wherever a chance variation ran in the direction of heightening and intensifying the natural grace of form which is implied in their specialised wading adaptations, it was seized upon and perpetuated by selective preference. Hardly a single dominant wader is devoid of some marked decorative adjuncts, which set off and interpret the native utilitarian beauty of his slender figure. In many cases, as in that of the ruff (whose name sufficiently describes his ornamental character), these decorated birds 
are polygamous - which of course allows of only the very handsomest males in each generation securing themselves a harem. The decorative crests and plumes are always fully and ostentatiously displayed before the hens during the pairing season, and in some cases are produced at that time alone. But as to bright colour, only a few outlying southern waders, like the ibis and the flamingo, living among the big waterlilies and marsh-flowers of African valleys, ever have a trace of it: and even these few cases cannot compare in variety or richness of hue with the typical fruit-eaters and flower-feeders. 


\section{XII.}

A BED OF NETTLES.

REACHIng my hand into the hedgerow to pick a long, lithe, blossoming spray of black bryony-here it is, with its graceful climbing stem, its glossy heart-shaped leaves, and its pretty, greenish lily flowers-I have stung inyself rather badly against the nettles that grow rank and tall from the rich mud in the ditch below. Nothing soothes a nettle-sting like philosophy and dock-leaf; so I shall rub a little of the leaf on my hand, and then sit awhile on the Hole Farm gate here to philosophise about nettles and things generally, as is my humble wont. There is a great deal more in netties, I believe, than most people 
are apt to imagine; indeed, the nettlephilosophy at present current with the larger part of the world seems to me lamentably one-sided. As a rule, the sting is the only point in the whole organisation of the family over which we ever waste a single thought. That is our ordinary human narrowness: in each plant or animal we interest ourselves about that one part alone which has special reference to our own relations with it, for good or for evil. In a strawberry, we think only of the fruit; in a hawthorn, of the flowers; in a deadly nightshade, of the poisonous berry; and in a nettle, of the sting. Now I frankly admit at the present moment that the nettle-sting has an obtrusive and unnecessarily pungent way of forcing itself upon the human attention; but it does not sum up the whole life-history of the plant in its own one peculiarity for all that. The nettle exists for its own sake, we may be sure, and not merely for the sake of occasionally inflicting a passing smart upon the meddlesome human fingers. 
However, the sting itself, viewed philosophically, is not without decided interest of its own. It is one, and perhaps the most highly developed, among the devices by which plants guard themselves against the attacks of animals. Weeds or shrubs with juicy tender leaves are very apt to be eaten down by rabbits, cows, donkeys, and other herbivores. But if any individuals among such species happen to show any tendency to the development of any unpleasant habit which prevents the herbivores from eating them, then those particular individuals will of course be spared when their neighbours are eaten, and will establish a new and specially protected variety in the course of successive generations. It does not matter what the peculiarity may be, provided only it in any way deters animals from eating the plant. In the arum, a violently acrid juice is secreted in the leaves, so as to burn the mouth of the aggressor. In the dandelion and wild lettuces, the juice is merely bitter. In 
houndstongue and catmint, it has a nauseous taste. Then again, in the hawthorn and the blackthorn, some of the shorter branches have developed into stout sharp spines, which tear the skin of would-be assailants. In the brambles, the hairs on the stem have thickened into pointed prickles, which answer the same purpose as the spines of their neighbours. In the thistles, the gorse, and the holly, once more, it is the angles of the leaves themselves which have grown into needle-like points, so as to deter animals from browsing upon them. But the nettle probably carries the same tendency to the furthest possible limit. Not content with mere defence, it is to some extent actively aggressive. The hairs which clothe it have become filled with a poisonous irritating juice ; and when any herbivore thrusts his tender nose into the midst of a clump, the sharp points pierce his naked skin, the liquid gets into his veins in the very neighbourhood of the most sensitive nerves, and the poor 
creature receives at once a life-long warning against attacking nettles in future.

The way in which so curious a device has grown up is not, it seems to me, very difficult to guess. Many plants are armed with small sharp hairs, which act as a protection to them against the incursions of ants and other destructive insects. These hairs are often enough more or less glandular in structure, and therefore liable to contain various waste products of the plant. Suppose one of these waste products in the ancestors of the nettle to be at first slightly pungent, by accident, as it were, then it would exercise a slightly deterrent effect upon nettle-eating animals. The more stinging it grew, the more effectual would the protection be; and as in each generation the least protected plants would get eaten down, while the more protected were spared, the tendency would be for the juice to grow more and more stinging till at last it reached the present high point of development. It is noticeable, too, that in 
our warrens and wild places, most of the plants are thus more or less protected in one way or another from the attacks of animals. These neglected spots are overgrown with gorse, brambles, nettles, blackthorn, and mullein, as well as with the bitter spurges and the stringy inedible bracken. So, too, while in our meadows we purposely propagate tender fodder plants, like grasses and clovers, we find on the margins of our pastures and by our roadsides only protected species, such as thistles, houndstongue, cuckoo-pint, charlock, nettles (once more), and thorn-bushes. The cattle or the rabbits eat down at once all juicy and succulent plants, leaving only these nauseous or prickly kinds, together with such stringy and innutritious weeds as chervil, plantain, and burdock. Here we see the mechanism of natural selection at work under our very eyes.

But the sting certainly does not exhaust the whole philosophy of the nettle. Look, for exanple, at the stem and leaves. The 
nettle has found its chance in life, its one fitting vacancy, among the ditches and wasteplaces by roadsides or near cottages; and it has laid itself out for the circumstances in which it lives. Its near relative, the hop, is a twisting climber; its southern cousins, the fig and the mulberry, are tall and spreading trees. But the nettle has made itself a niche in nature along the bare patches which diversify human cultivation; and it has adapted its stem and leaves to the station in life where it has pleased Providence to place it. Plants like the dock, the burdock, and the rhubarb, which lift their leaves straight above the ground, from large subterranean reservoirs of material, have usually big, broad, undivided leaves, that overshadow all beneath them, and push boldly out on every side to drink in the air and the sunlight. On the other hand, regular hedgerow plants, like cleavers, chervil, herb-Robert, milfoil, and most ferns, which grow in the tangled shady undermath of the banks and thickets, have 
usually slender, blade-like, much-divided leaves, all split up into little long narrow pushing segments, because they cannot get sunlight and air enough to build up a single large respectable rounded leaf.

The nettle is just half-way between these two extremes. It does not grow out broad and solitary like the burdock, nor does it creep under the hedges like the little muchdivided wayside weeds; but it springs up erect in tall, thick, luxuriant clumps, growing close together, each stem fringed with a considerable number of moderate-sized, heartshaped, toothed-and-pointed leaves. Such leaves have just room enough to expand and to extract from the air all the carbon they need for their growth, without encroaching upon one another's food supply (for it must always be borne in mind that leaves grow out of the air, not, as most people fancy; out of the ground), and so without the consequent necessity for dividing up into little separate narrow segments. Accordingly, this type of 
leaf is very common among all those plants which spring up beside the hedgerows in the same erect shrubby manner as the nettles. It is almost exactly imitated in the deadnettle and the hemp-nettle, which are plants of a totally distinct family, with flowers of the sage and rosemary type ; and it is more or less simulated by ten or twenty other species of like habit. This peculiarity of external resemblance, under identical circumstances, between organisms wholly unlike in origin and pedigree, is a common and natural one. Thus, in the dry deserts of India, some of the spurge tribe grow thick and succulert, so as exactly to resemble the genealogically very different cactuses of like dry deserts in America; and a gallinaceous bird, stranded on the shores of the Antarctic Islands, has acquired the long legs of the waders, together with the characteristic colours of the gulls. Whatever the original stock, natural selection tends always under like circumstances to produce like results. 
Then, again, there is the flower of the nettle, which in most plants is so much the most conspicuous part of all. Yet in this particular plant it is so unobtrusive that most people never notice its existence in any way. That is because the nettle is wind-fertilised, and so does not need bright and attractive petals. Here are the flowering branches, a lot of little forked antler-like spikes, sticking out at right angles from the stem, and half concealed by the leaves of the row above them. Like many other wind-fertilised flowers, the stamens and pistils are collected on different plants - a plan which absolutely ensures cross-fertilisation, without the aid of insects. I pick one of the stamen-bearing , clusters, and can see that it is made up of small separate green blossoms, each with four tiny leaf-like petals, and with four stamens doubled up in the centre. I touch the flowers with the tip of my pocket-knife, and in a second the four stamens jump cut elastically as if alive, and dust the white pollen all over my fingers. Why should they act 
like this? Such tricks are not uncommon in bee-fertilised flowers, because they ensure the pollen being shed only when a bee thrusts his head into the blossom; but what use can this device be to the wind-fertilised nettle? I think the object is somewhat after this fashion. If the pollen were shed during perfectly calm weather it would simply fall upon the ground, without reaching the pistils of neighbouring plants at all. But by having the stamens thus doubled up, with elastic stalks, it happens that even when ripe they do not open and shed the pollen unless upon the occurrence of some slight concussion. This concussion is given when the stems are waved about by the wind; and then the pollen is shaken out under circumstances which give it the best chance of reaching the pistil.

Finally, there is the question of fruit. In the fig and the mulberry the fruit is succulent, and depends for its dispersion upon birds and animals. In the nettle it takes the form of a tiny seed-like flattened nut. Why 
is this, again? One might as well ask, why are we not all Lord Chancellors or Presidents of the Royal Academy. Each plant and each animal makes the best of such talents as it has got, and gets on by their aid; but all have not the same talents. One survives by dint of its prickles; another by dint of its attractive flowers; a third by its sweet fruit ; a fourth by its hard nut-shell. As regards stings, the nettle is one of the best protected plants; as regards flower and fruit, it is merely one of the ruck. Every plant can only take advantage of any stray chances it happens to possess; and the same advantageous tendencies do not show themselves in all alike. It is said that once a certain American, hearing of the sums which Canova got for' his handicraft, took his son to the great man's studio, and inquired how much he would ask to make the boy a sculptor. But there is no evidence to show that that aspiring youth ever produced an Aphrodite or a Discobolus. 


\section{XIII.}

LOOSESTRIFE AND PIMPERNEL.

I HAVE picked this long delicate spray of woodland loosestrife - a pretty, graceful, small creeping flower-in the deep thickets of Netherden Spinney, where its slender trailing stems grow abundantly under the damp shade of the young alder bushes. It does not in the least resemble the big erect purple loosestrife, that handsome tall waterside plant, whose great bunches of brilliant flowers hang so heavily over the banks of brooks and rivers a little later in the season; for, indeed, the two species have no connection with one another except etymologically, and derive their common name from different 
sources, the one truly English, the other as a mere herbalist's translation of the Greek lysimachia. The woodland loosestrife has small yellow flowers, of a regular and simple sort; and it is by family a primrose, though it hardly looks much like one to a casual observer. I have picked it now, however, for comparison with this other allied plant, the common little pimpernel, whose pretty bright red blossoms are familiar friends in every cornfield and waste patch of garden. The two plants are very interesting in their way, as illustrating a curious feature of evolution; and they are interesting, too, as showing the sort of errors into which people were constantly led before the rise of evolutionism by the old artificial way of regarding the relationships between plants and animals.

In all the books about botany, even, I believe, to the present day, you will find the woodland loosestrife classed as a species of the genus Lysimachia, while the pimpernel is classed as a species of the genus Anagallis. 
But in reality, looking at the matter from the new standpoint of descent or actual pedigree, there can be very little doubt that this particular loosestrife is far more closely related to the pimpernel, which is thus placed in a separate genus, than to the other yellow loosestrifes which are included in the same genus with it. The reasons that induced the older botanists to make this classification are clear enough, and they seemed at the time perfectly cogent; nay, they have not yet been discarded, I fancy, by any of our modern reformers, though no doubt they will be so as soon as the question is once fairly considered at scientific headquarters. The loosestrife genus was defined as having a capsule opening at the top when ripe in five or ten valves; the pimpernel genus was defined, on the contrary, as having a capsule opening in the middle, by a line running round it transversely instead of longitudinally. If we consider the capsule as represented by a common terrestrial globe, joined to the 
stalk at the south pole, then in the loosestrifes this capsule may be figured as dividing into several segments along the meridians from the north pole downwards; while in the pimpernels it may be figured as dividing into two hemispheres at the equator. It is just the difference between letting an orange burst open along the natural partitions, or cutting it across the middle at right angles to the partitions. Now, if you look closely at the ripe capsules of the woodland loosestrife, you will see that it splits asunder into separate valves; and, therefore, according to this rule, it is a true lysimachia : while if you look closely at the ripe capsules of the pimpernel, you will see that the top lifts off bodily in a hemisphere or cup, displaying the seeds within as an uncovered sphere; and therefore, on the same principle, it is a true anagallis. So far as this reasoning goes, it is perfectly just and accurate.

But now, again, if we inquire into the development and history of the two plants, 
we shall probably come to a very different conclusion. Most of the primrose family, to which both genera belong, have capsules opening by valves; only two or three peculiar species, like the common pimpernel, the bog pimpernel, and the tiny chaffweed, have capsules opening by a lid which lifts off in a single piece. Therefore the presumption is that the latter forms are derived from the former, and not vice versâ, especially as the valvular mode of opening is a common one among ali plants, while the transverse mode is extremely unusual.

But we have something more than such a presumption; we have an actual relic of the earlier liabit impressed still upon the very structure of the pimpernel. If you look carefully into its half-ripe capsules (with a small pocket lens, or even without one) you will see five dark brown lines traversing the top of the sphere, from the pole towards the equator, exactly like the meridians on a globe. These are the marks of the valves by which the 
capsule used once to open. In the yellow loosestrife you will find exactly similar marks; only in that case they are the lines along which the capsule actually splits when ripe; whereas in the pimpernel they only simulate such a purpose beforehand, while the actual mode of opening is by a transverse division. There can be no doubt at all, therefore, that the pimpernel is really directly descended from an ancestor which closely resembled the woodland loosestrife; and that the present peculiarity in its method of opening is quite a modern or recently acquired habit. Otherwise, it would not still retain the five valve-marks on the halfripe capsule so very distinctly as it still does.

In every other respect except this one point the woodland loosestrife much more closely resembles the pimpernel than it resembles the other members of its own genus. Both are slender trailing plants, with leaves of much the same character; both have small flowers of the same general 
type, on long thin stalks, which roll back as the capsule ripens; and both have a certain indefinite likeness to one another in the vague points of external appearance, which botanists describe as 'habit.' It is true, the blossoms of the woodland loosestrife are a pale delicate yellow, while those of the pimpernel are bright orange-red; but that is a small matter mainly dependent upon their insect fertilisers and their different distribution, the one plant loving shady copses or moist woods, while the other loves open cornfields and dry barren places. In general shape, however, and in all important characters, the klossoms are simply identical.

It is impossible, therefore, to resist the conclusion that the pimpernel is descended, either from the woodland loosestrife itself, or from some common parent form extremely like it. For almost all the distinctive peculiarities of the pimpernel, except only its trick of opening in the middle, must have been acquired by the parent form before it K 2 
began to split up into two separate species. The woodland loosestrife, remaining in damp tree-covered spots, has most closely retained the general appearance of the common ancestor, since its flowers are yellow, like those of the other loosestrifes, and its capsule still opens in longitudinal valves. The pimpernel, on the other hand, growing in those bare patches which human tillage renders so common, has become a frequent weed of cultivation over all Europe and half Asia, and has accompanied man in his various migrations throughout nearly the whole globe. For some reason or other-why, it is hard to say-it has found the transverse mode of opening its capsule suit it better than the valvular, perhaps because this plan saved its seeds in some unknown way from some dangerous animal foe ; and so it has universally adopted the new principle in place of the old one. It has also changed the colour of its flowers, through the selective action of the fresh insect fauna to which it was exposed 
under the altered conditions of its life. And, finally, it (or some similar form) has further developed the bog pimpernel and half a dozen other more separate species, as well as the still further differentiated chaffweeds, which depart progressively more and more widely from the common loosestrife pattern.

The fact is, fruits and seeds are naturally in one way the worst of all possible guides to relationship by descent; because, though close likeness in fruits affords a fair presumption of close kinship, unlikeness in fruits affords no valid presumption against it. Two plants may remain alike in their leaves, their stems, their buds, and their flowers, and yet when it comes to their fruit, new agencies may be brought to bear upon them which for the first time set up a slight difference between them. This difference may often be very conspicuous, and yet may be of extremely little genealogical importance. Thus the almond and the nectarine are really so much alike in all general points of structure 
that one may say they are practically the very self-same plant; cnly in the almond, the fruit has a hardish shell, while in the nectarine it has acquired a soft one through the selective action of birds. Similarly, there is a common English potentilla which exactly resembles a strawberry in everything except the fruit, and that is dry instead of being succulent. Here we may fairly say that the strawberry is just such a potentilla, whose seed receptacle has become juicy and red, through having been eaten by birds, which aided in dispersing its seeds. The old botanists made the strawberry into a separate genus because of this conspicuous difference; but in reality the difference is worth very little as an indication of distinctness, for the potentilla had already acquired every distinctive trait of the strawberry, save only this one noticeable trait of a succulent fruit-stem, long before they diverged from one another; and that one peculiarity might be and actually was easily acquired without any change in the general habit of the species. 
In all these cases a philosophical biologist can but come to one conclusion. Not only does the strawberry not differ generically from the potentillas, but it is merely a slightly divergent form of this particular potentilla, which is much more closely related to it than to the other members of the artificial genus. And so, too, not only does the pimpernel not differ generically from the woodland loosestrife, but it is merely a slightly divergent form of that particular loosestrife which is much more closely related to it than to the other members of the genus Lysimachia. 


\section{XIV.}

THE CARP POND.

THE little stretch of artificial water in Chilcombe Hollow, put there to form an element in the view from the drawing-room windows of the manor-house, positively teems with great, fat, lazy carp, whose broad dark backs I can just distinguish through the pond when they sail across slowly from one waving bunch of weed to another in their heavy, lumbering, overfed way. There is a certain natural congruity between the carp and the pond-natural, I mean, in the sense that both are highly artificial, just as we might say that a shepherdess in silk skirts with a pastoral crook was perfectly natural in a fete champetre of the 
Watteau order. For carp are the most absolutely domesticated of all fishes, except their near relations the goldfish; and they have consequently undergone the usual amount of distortion and degradation which domestication brings in its train. Some have lost their scales altogether; some have grown short and stumpy, others lean and low ; and some have got their fins lengthened into a perfect caricature of their natural selves. Carp, in fact, come to us from China, where they have been kept in artificial ponds from time immemorial, after the usual Chinese fashion; and they have been carefully bred and selected for their monstrosities and oddities, which pleased the Celestial taste, exactly as in the case of those marvellous varieties of the golden carp, with expanded tails and stalked eyes, known as telescope fish, that one sometimes sees in domestic aquariums. In England, it is true, the carp are comparatively modern denizens; for, in spite of the popular notion that they were largely bred in medixvai 
monasteries, modern naturalists have decided that they were first introduced here early in the seventeenth century. Yet there is still a certain artificial pond-bred look about them, which makes them harmonise well with these dammed-up sheets of ornamental water. The swift speckled trout suits the stickles and reaches of our own native becks ; but the lazy carp suits the slow stagnant pools which are forced upon our unwilling scenery by checking the brooks midway on their course through their proper sloping English combes.

Originally, however, the habits and manners of the carp family were very different from those which this particular species has acquired in the sluggish streams, broad lakes, and banked up ponds of the Chinese lowlands. Dr. Günther, our greatest living authority on the study of fishes, has traced the migration and differentiation of the family from its earliest form in its primitive home to its numerous divergent branches over the 
whole northern hemisphere; and his account is one of the most instructive studies in the geographical distribution of animals that has yet been attempted. At the present day these cyprinoids form one-third of all the fresh-water species of fish known to science. Yet they seem to be a comparatively modern family, not being found in earlier geological deposits than those of the tertiary age. Apparently, the primitive ancestral carp was evolved from some earlier species in the great Himalayan range which divides the temperate and tropical parts of Asia. This was a splendid starting-place for a new family, since the rivers which take their rise in the Central Asian backbone ridge flow in every direction towards the Arctic, the Pacific, and the Indian Ocean, as well as towards the Aral Sea, which once communicated with the Caspian, and so gave access to the rivers of Russia. The primitive cyprincids accordingly set out on their travels towards the plains on every side; and as they went they accommodated 
themselves step by step to the most varying tropical or sub-Arctic conditions. Those which descended the rivers into India became the ancestors of the beautiful carp-like fishes of the Ganges and the Indus. Those which slowly made their way into China gave birth to the domestic carp, the goldfish, and many other species. And those which still more slowly spread into the outlying peninsular tract of Europe differentiated themselves into our familiar barbels, gudgeons, tench, chubs, dace, roach, and minnows.

From Europe the carp kind made their • way into the New World. As early as the pre-glacial epoch, fossil forms show us that the cyprinoids had already migrated into America, no doubt across the fresh waters in the belt of land which once lay upon the high submarine bank between Scotland, Iceland, and Greenland; and the descendants of these primitive immigrants now form the suckers, white mullets, shiners, whitefish, and red-fins of the Canadian lakes and rivers. Thus the 
cyprinoids have spread over the whole of the old Continent and of North America. But the sea forms the great barrier in the way of migration for fresh-water creatures; so that they have not yet been able to get beyond the limits of this northern land-surface, long united in a single continent by the elevation of the Icelandic bank. Australia we know has never been joined to Asia or the rest of the world since the cretaceous period at least, and therefore there are no cyprinoids in Australia. South America has only recently been linked to the northern continent by the elevation of the narrow mountain belt at Panama which causes so much trouble to M. de Lesseps, and it still preserves for the most part its own very antiquated and isolated fauna of llamas, alpacas, armadillos, sloths, and ant-eaters; so that into South America too the cyprinoids have not yet had time to penetrate. Of course they are equally absent from the islands of the Pacific, cut off as those oceanic archipelagos are from all the 
rest of the world by a broad and practically impassable stretch of deep sea. If one might hazard a guess as to the future, apart from the interference of man, it is most likely that the carps will first pass down the Isthmus of Panama into the rivers of the Andes, and thence, as the mountain species gradually accustom themselves to lowland tropical conditions, into the Amazon valley; that their invasion of Australia must be deferred till some slow secular elevation has done away with Torres Straits and the Java Sea; and that in all human probability they will never naturally get over the obstacles which seem to shut them out for ever from the archipelagos of the Pacific.

In their origin the cyprinoids were thus Alpine fishes of the torrents, not lazy lurkers on the muddy bottoms of inland ponds. It is only the accident of their long residence among the great alluvial levels of the Chinese basins which has given our own domesticated carp their distinctive specific features. Most 
of the cyprinoids are still lovers of running water, and many species still haunt the upland torrents of their native Central Asian home. Another family, the siluroids, is by descent the really typical group of muddy water fishes. In England, we have no siluroids-our streams are too pure and clear and rapid for them-but in Germany the slow rivers of the eastern plains support the big wels, and in America the cat-fishes are found abundantly in all swamps and shallow waters of the great central level. Dr. Günther has traced the migrations of this important group, as well as those of the carps-they form now about one-fourth of all known freshwater species-and has shown pretty certainly whence they came and how far they have gone. The siluroids are essentially fishes of the sluggish waters in the plains, and they seem to have had their origin in tropical countries, where they still flourish best. They have no scales, but are clad in a slippery skin; and they have always long 
barbels, which apparently fit them for a marshy or muddy life. Probably they were developed at a later date than the carps; for, while we find fossil cyprinoids abundantly in the tertiary freshwater limestones of Oeningen and Steinheim, in the lignites of Bonn and Bilin, in the slates and shales of Sicily and Sumatra, and even in the Idaho deposits of North America, we find no fossil siluroids in the European tertiaries at all, nor anywhere nearer than the fresh-water strata of the Malay Archipelago. Hence we may fairly conclude that at a period when the carps were already widely spread over the whole northern hemisphere, the cat-fish were still mainly confined to the neighbourhood of their original tropical home.

Nevertheless, the primitive siluroid had some striking advantages on his side, which have enabled his descendants to outstrip the carps, considering their juniority in time, in the race for the occupation of the fresh waters of the world. Not only does their skeleton 
show certain very special modifications, adapted to their peculiar mode of life, but they are also comparatively cosmopolitan in their tastes, being able to enter the sea, to which some species have taken permanently, though still keeping for the most part to shallow muddy bottoms. As they are thus but little deterred by intervening oceans, they were enabled to spread rapidly over the whole of the tropics, reaching Northern Australia from India, and even crossing from South America to the Sandwich Islands. As yet, however, they have not made their way into the coral islands of the Pacific. Northward they spread far more slowly, as they are no lovers of cold water. Only one species has penetrated into Europe, and but few into temperate Asia. The North American kinds, though more numerous, belong all to a single group. Towards the south temperate regions, where the land tapers slowly southward, they spread slowest of all; so that the family is entirely wanting in Tasmania, New 
Zealand, and Patagonia. Facts of distribution like these were utterly meaningless before we obtained the key of evolutionism ; but with that key to open their meaning they become at once speaking evidence as to the former migrations and relative descent of the whole group of creatures to which they refer. 


\section{XV. \\ A WELSH ROADSIDE.}

Beyond Pensarn the walk begins to grow tame and somewhat tedious. Half-way to Dyffryn, it is true, the long low range of the Llawllech hills is cleft by the little torrent valley of the Artro; and just there the view opens up behind into the beautiful glen of Cwm Bychan, backed by the grand bald summits of the two Rhinogs and their sister hills. But beyond this one glimpse of the wild mountain country in the rear, the highway becomes decidedly dull and monotonous. On one side stretches the lowland, protected from the sea by a succession of blown sand dunes, which almost hide the horizon with 
their line of stunted mounds: on the other side rises the dreary unbroken range of Llawllech, a mere treeless slope of scanty barley and stony pasture land. To right and left, the lane itself-for it hardly deserves to be called a road-is bounded by stone walls, which often shut out what little view might otherwise be obtained over flat shore, distant sea, or barren hillside; so that altogether, for the mere lover of the picturesque, the six miles' walk hence to Barmouth forms a very uninteresting termination to a pleasant and diversified day's tramp.

To the geological eye, however, even the dullest scenery often presents objects of special interest which would never strike the casual unscientific observer. Railway cuttings, which appear to most people mere blank interruptions of the general prospect, assume for the enthusiastic geologist the guise of delightful sections made on purpose to display to him the nature and succession of the strata. Just so this somewhat weary 
bit of walled-in Welsh lane is fraught with much interest of its own for those who choose to look at it aright. For the boundary walls are built, not of square-quarried stone, but of round and shapeless boulders, often thickly dappled with patches of grey or orange lichen, and loosely piled together, in rough primitive fashion, without cement or mortar. If one examines them closely they prove also to be scratched and grooved with parallel lines; and these lines the geologist at once recognises as due to the grinding action of glaciers. The boulders, in fact, were transported hither by the great ice-sheet which once covered the whole country side hereabouts, and which ran out far into the bed of what is now the Irish sea.

Indeed, the entire side of Llawllech consists for the most part of one huge moraine, a mere mass of glacial débris, mainly made up of fine mud, with ice-worn boulders and pebbles disposed loosely through its midst, like raisins and currants in a school plum- 
pudding. That is what makes this low range so monotonous and uniform in surface; it displays no jagged and weathered craggy rocks, no deep glens cut by ice or rivers, but it still shows for the most part only the long rounded sloping contour of the original moraine, slightly cut through in places by uninteresting streams. In the railway cuttings below one can admirably see the composition of the moraine, with its ground-tone of mud and its interspersed boulders; while here by the roadside one finds just the selfsame boulders, picked off the ground for the sake of a clearance, and piled up loosely to make a rude stone wall. In the Srowdon district, especially along the pretty drive through Nant Gwynant from Beddgelert to Capel Curig, numbers of sections have been made in the moraines for road metal, the hard boulders being dug out and broken up for this utilitarian purpose; and on the slopes above, near the mountain tarn of Llyn Llydaw, one may still observe the huge 
bossed surfaces of the native rock worn by. the glaciers which heaped up these refusepiles-roches moutonnées, as they call them in Switzerland-perfect domes of bare stone, even now sharply grooved and marked with the striæ scratched upon them by the superincumbent ice-stream.

It is impossible to avoid noticing that the walls are very much thicker than they need be for any practical purpose; indeed, in some places they are as much as four or five feet broad. The truth is, such walls are rather a simple way of getting rid of the boulders than a protective margin to the fields. In trying to cultivate these glacial slopes, the first thing to do is to weed out the surface boulders ; and the easiest plan of doing so is to pile them up all round the stubbed portion of the field. The thickness of the wall depends upon the number of the boulders. Where they are many the field is small and the wall big; where they are few the field is larger and the wall not quite so clumsy- 
looking. In some places, however, even the wall does not suffice to use up all the loose fragments; and then they are often packed in the corners so as to cant the angles with a small flat-topped triangular platform. Of course the very stoniest bits are wholly unenclosed, or given over to mountain sheep, who find a scanty pasture in the chinks between the boulders; and the valleys of the little rivulets are almost always mere gorges of naked round stones, because here the water has washed away all the soft earth between them. Such denudation is always going on more slowly, even in the other parts; and the plain or marshland which lies between the foot of the hills and the sea has been built up by the detritus thus carried down from the moraines, and protected from incursion by the hillocks of blown sand.

It is interesting, however, to think that every one of these big round stones has been once like ourselves a tourist, and has travelled on the side or bottom of a glacier to its pre- 
sent place, and that, too, at a date long subsequent to the undoubted arrival of man upon the earth. It was many ages after the lowbrowed black-fellows hunted the rhinoceros and the mammoth in the swamps of Gray's Inn and the jungles of Fleet Street, that the ice-sheet bore these boulders down the sides of Llawllech to this big moraine. Some of the smaller pebbles may even once have been shapely stone hatchets of palæolithic man, long since ground down into indistinguishable roundness by the enormous friction of the moving glacier. In most cases, one can go so far as to decide actually where the boulders come from by the nature of the rock from which they are derived; this bit must have been broken off the side of Aran, that bit must have been detached from the summit of Rhinog, and this other again must have travelled all the way from the slopes of the Berwyns. But, if any of them ever bore any trace of human workmanship, all semblance of manufactured articles has long been worn 
away from their surface by the grinding icemill. It is only in the protected floors of flooded caves or among the subsisting drift of glacial and interglacial rivers that we can now find any traces of man's early handicraft. Everywhere else the ice-sheet has planed everything bodily off the face of the land: that is why we find few or no palæolithic skeletons. And we must never forget, in estimating the past history or present fauna and flora of England, that this total blank in our geological and archæological annals cuts in like a complete interruption between the two known ages of human life in this island. Everything that existed in Britain before the last great ice-age was cleaned utterly off the face of the country by the vast system of glaciers which then grew up ; everything that now exists in it has come into the land since the date of that gradual but all-embracing cataclysm. The men, the animals, the plants which lived here before the ice covered the country belonged to extinct types, or to 
species now confined to southern climates; when the ice cleared away it had swept off almost every relic of their existence, and a new race, a new fauna, and a new flora, came to occupy the virgin soil. 


\section{XVI.}

SEASIDE WEEDS.

BEHIND the bar which closes the wide throat of the estuary here at Stourmouth a long expanse of sand stretches away inland almost as far as the weirhead that marks the highest point of tidal action in the little river. Some of this sand lies below the level of high water, and is therefore very soft and smooth and muddy; but a large portion of it stands always high and dry, blown about into uneven ridges and hollows by the strong winds that rush down the opening between the two parallel ranges of neighbouring hills. As I sit upon one of these ridges watching the slow clouds drifting landward before the 
westerly breeze, I have picked from between the sand a little creeping weed, root and all, with thick, fleshy, cylindrical leaves, and a stout thorn at the end of each. It is a common seaside plant-saltwort or kali ; and, like sand-loving plants generally, it has very succulent and juicy foliage. The reason for this fleshy habit under such circumstances seems clear enough. Marshy plants, or plants which live in ordinary moist soils, can get plenty of water whenever they want it, and so they need not store away any against emergencies in case of droughts. Even dry hillside shrubs, like the rosemaries and heaths, can thrust their roots deep into the earth, and so manage always to get a little supply of moisture, sufficient to keep their hard crisp foliage alive, and their sap slowly circulating, even in the driest summer weather. But weeds which live on sand must economise water whenever they can get it. The rain that falls upon the spots where they grow, sinks rapidly through the surface, and in a few 
hours the whole place is just as dryas it was before the shower. Accordingly those plants which have accommodated themselves to such situations have necessarily acquired very thick and fleshy leaves; and this acquisition was the easier to make, because proximity to the sea produces in all plants a slight succulent tendency. As soon as rain falls they drink up all the waterthat comes in the way of their spreading rootlets, and then they store it away in their broad leaves or thick stems till they require it for use. Just as the camel takes one long drink before starting, which supplies his wants for some days in the desert, so the saltwort takes one long drink at each shower and subsists upon that till the next rainfall.

The history of this seaside weed can be easily traced by means of its own existing structure. By origin it is one of the goosefoots, a family of small weedy-looking plants, which grow abundantly in all waste places and over heaps of rubbish near cultivated ground. 
The flower of the kali, indeed, is still essentially a goosefoot flower-a mere inconspicuous little green blossom, hidden in the angle between the stem and the leaves, after the fashion of many plants which have not learnt how to develop bright petals for the attraction of insects. But the goosefoots, in the course of their spread over the earth, would often shed their seeds upon sandy places; and being as a rule originally rather disposed to fleshiness, especially in the stems, they must often have managed to live on even in these unfavourable situations where most other plants would starve or wither outright. Of course only the very fleshiest specimens would survive to blossom and set their seed; and these seeds, again, would produce young plants, most of which would be just as succulent as their parents, while a few would doubtless surpass them in this respect. As such natural weeding out of the least adapted forms would occur with every drought, and as the best adapted which lived through the 
droughts by virtue of their superior fleshiness would occasionally cross with one another, either by wind-fertilisation or by stray visits of pollen-hunting midges, it is clear that in the course of time a new succulent species would be slowly evolved. As a matter of fact, the goosefoots have really given origin to several such sand-loving weeds, each of the principal groups having probably a separate origin from some particular kind of strictly terrestrial goosefoot.

After the saltwort had grown succulent it began also to grow prickly. For sand-loving plants are naturally exposed to very great danger from herbivorous animals, against which they are accordingly compelled to protect themselves by some hostile device. In the first place, there is comparatively little vegetation on sandy spots, so that each plant runs an exceptional chance of being eaten. Then, again, the succulence and juiciness of sand-haunting weeds make them particularly tempting to thirsty animals, which are sure to 
eat all unprotected specimens. Hence, as a rule, only those survive which happen to have developed some unpleasant personal peculiarity. Many sand-haunting or desert plants are more or less pungent or have disagreeable alkaline essences stored up in their leaves; and these alkaline constituents, which they easily obtain from the soil, formerly caused many of them (saltwort and glasswort among the number) to be burnt for barilla. In avoiding the Scylla of animal tastes such plants fell into the Charybdis of human industrial usages. But most sand-loving weeds have solved the difficulty in another way by simply acquiring thorns or prickles. In the saltwort, each leaf ends in a stout spine, which of course runs into the nose of any too inquiring cow or donkey. In many cactuses, again, the leaves have been reduced to sharp thorns, which cover the surface of the cylindrical stem, and form the most effectual possible protection against the attacks of animals. In the West Indies, cactus hedges line all the 
roads in the plains, and rise in a solid wall to a height of fifteen or twenty feet. No animal on earth dare attempt to pass through such a hedge; and the task of cutting one down, when necessary, is extremely difficult. On bare dry expanses, like the Mexican plain, cactuses and agaves run wild in every direction, collecting what little moisture they can in their thick stems or big succulent leaves, and defending it against herbivorous enemies by their formidable spines. To prevent evaporation, they are covered by a thick and very firm epidermis, so that they lose very little of their moisture even during months of drought.

What these great desert plants do on a large scale, our little English saltwort does on a much smaller scale. It has the same strong prickles, the same thick, juicy leaves, the same protective epidermis, and the same general aspect or habit of growth as the cactuses themselves. If one were to enlarge it twentyfold, every casual observer would 
set it down as a desert species at once. Indeed, so naturally do all these peculiarities result from the mode of life affected by sand-haunting plants, that in India, where there are no true cactuses, certain native spurges are universally known by that name, because they so exactly resemble them in general external appearance. By pedigree the two families are wholly unconnected; but in America certain weeds of a kind something like our own stone-crops and houseleeks, having got loose on the sand-wastes of the tropical belt, adapted themselves by their succulence and their defensive prickles to the necessities of their new situation, while in Asia certain totally distinct weeds of a kind closely resembling our spurges and mercuries happened to establish themselves on the similar sand-wastes of sub-tropical India, and necessarily adapted themselves in just the same manner to just the same sort of situations.

In fact, we now know that these adaptive 
and functional resemblances are the worst possible guide to relationship by descent. Almost all plants which grow under water have very finely divided leaves; but they are all aberrant members of the most diverse and widely separated families. They have been compelled to acquire long, thin, waving leaflets because there was so little carbonic acid in the water where they lived that they could not extract carbon enough from it to build up a full, large, round type of leaf; exactly as all aquatic animals have muchbranched gills to catch the stray floating particles of free oxygen dissolved in the water, while all land-animals have big internal lungs, into which the abundant free oxygen of the atmosphere pours copiously at every inhalation. Put any two distinct groups of plants or animals into exactly similar circumstances, and the chances are that they will adapt themselves to those circumstances in exactly similar ways, thus masking their original unlikeness. But if you 
examine their minute internal structure, you will probably still find many small points of deep-seated difference, underlying their external adaptive similarity; and these points are the important clues which aid us in discovering their real relationship to unlike groups elsewhere. Thus the humming-birds of America and the sun-birds of India are extremely similar in outer appearance, because they are both highly adapted to a flower-feeding existence; but their minute anatomy shows that the one family are modified swifts or swallows, while the other family are modified tropical fruit-eaters. Hence we are landed at last in the apparent paradox so ingeniously pointed out by $\mathrm{Mr}$. A. R. Wallace, that the less functionally useful any structure may be, the greater becomes its value as a test of relationship by descent. 


\section{XVII.}

\section{A MOUNTAIN TARN.}

ONE could not find many pleasanter seats in England, or Wales either, than this big dry boulder, with a niche that seems intentionally designed to accommodate the contour of the human backbone, overlooking the calm surface and bare craggy sides of a little mountain tarn. I have come up here this morning on sport intent, to find a specimen of a peculiar species of trout, which haunts this one tiny sheet of water, and occurs nowhere else in the whole universe. Not that I am an active sportsman myself; my portion of the service is always confined to the attitude of those who stand and wait; and I don't even 
stand to-day, having found so comfortable a seat in the water-worn hollows of a granite boulder. But the young landscape painter from Manchester, who is making such a pretty picture of the glen from his tent close by, can throw a fly as well as any man in Lancashire; and when I mentioned to him some time since my wish to get one of these local trout as a specimen for examination, he promised to entice one up for me on the very first morning when the light was unpropitious for sketching in the glen. To-day he dropped in after breakfast to tell me he could spare me a few hours for fishing; so here we are beside the tarn, and here is the Llyn Gwernant trout in person, flapping and floundering on the bare rock at my side-poor creature! -in its last gasps, while I am calmly prepared to watch and report upon its specific peculiarities. I have certain compunctions of my own about the morality of catching a live trout for such a purpose; but as my artist friend still continues angling for more, 
which, when caught, I shall doubtless eat for supper with a clear conscience, I may as well stifle my scruples now, and take notes of my trout while he is still fresh and lifelike. After all, it is just as legitimate, I suppose, to catch a fish in the interests of science as to catch it for the sake of dishing it up at supper in a tempting brown case of egg and bread-crumbs.

There can be no doubt or hesitation about the right of the Llyn Gwernant trout to rank as a separate species. The marks which distinguish it from the common speckled trout of English brooks and rivers are many and undeniable. But the question how it came here is a very curious and interesting one. We have in Britain altogether some twelve kinds of trout, peculiar to our own islands; and most of them are limited, as in this case, to a single station, usually a mountain pool with only one precipitous outlet. On the old theory, which represented every species of plant or animal as the direct 
result of a special creation, we could have had no alternative but to suppose that each of these kinds of mountain trout was specially created in and for the particular little pool where we now find it. But the new theory of evolution simply teaches us that each trout has been evolved under peculiar circumstances to suit the special conditions of these isolated sheets of water in which they live. Let us look a little closely at the position of Llyn Gwernant, and consider why a unique kind of trout should have been evolved just there rather than elsewhere.

The tarn itself, one can see at a glance, must be a glacial hollow. It was scooped out by the grinding action of ice in the last glacial epoch. Look up the glen, and then down, and you will see that in either direction the valley widens out from the lake as a centre. But just about the neighbourhood of the lake itself the sides trend inwards, so as to enclose a small pass or gorge; and when the whole combe formed the bed of an 
ancient glacier, the ice in this part must have been crowded together into a narrow compass, and thus squeezed hard against the sides and bottom of the gorge by the pressure of the great ice-sheet in the rear. If you look at the rock anywhere around the lake you will see that it is worn quite smooth and deeply scratched with ice-marks like those which occur just below the summer level of a glacier in Switzerland at the present day. So the rock-basin in which the tarn lies must itself be a product of the scooping action of the glacier. When the ice melted away under the genial climate of the post-glacial period, a little stream took the place of the vast frozen mass, and this stream expanded in the hollow till it filled the small lake and then ran out at the lower end. Hence the arrival of the trout in Llyn Gwernant must necessarily date from some period not earlier than the end of the last ice age. Whatever peculiarities they may display when compared with the parent type must have been de- 
veloped since that time. Indeed, even if the lake had been here before the glacial epoch, the ancestors of these trout could not have dwelt in it; for we know that every species of animal now living in Britain must necessarily have entered the island since the ice-sheet cleared away.

How did the trout first get into the tarn? That seems at first sight a difficult question, for the only stream that communicates with it is the little torrent, broken by a hundred small cascades, which drains its waters into the river below. No fish could now possibly leap up these continuous waterfalls from ledge to ledge, some of them as much as twenty or thirty feet high. Hence local naturalists have speculated not a little on the origin of the trout, one theorist suggesting that they were carried hither by a waterspout, another that the eggs were brought into the pool clinging to the feet of a waterfowl, a third that the ancestral fish were placed in situ by the finger of the Almighty. 
-which latter metaphor he does not deign to explain for us in full. For my own part, I do not incline thus clumsily to solve the problem with a deus ex machinâ; one cannot fairly consider it a dignus vindice nodus. It seems to me more likely that when the fish first came here the little stream still flowed in a moderately continuous basin, worn for it by the glacier, down to the level of the river, which then ran in a far higher channel than at present. $U_{p}$ this gentle incline the trout which were slowly spreading through the unoccupied fresh waters of Britain, after the thawing of the great ice-sheet, must have made their way into Llyn Gwernant.

But when they had once got there, the brook and the river went on carving their basins through the rock and the glacial soil, till at last they reached their present levels, the three highest falls on the brook being just those where it meets the newer valley of the main stream by Dolserau Mill. So after a while no more trout could reinforce the 
small colony in the tarn, which would thus have room to develop in their own way to suit their own peculiar circumstances, without any cross of fresh blood from the old stock to keep them true to the general type of the race in the lowland rivers. For, as Mr. A. $R$. Wallace has ingeniously pointed out, such isolated mountain pools are really the aquatic equivalents or analogues of oceanic islands. In all such limited and hermetically closed habitats every stray denizen is liable very rapidly to undergo considerable changes. The nature of the food-stuffs is new, and their variety but scanty; the enemies, if any, are fewer in number and different in kind; the conditions are in every way more restricted and more absolute than elsewhere. Hence we have here in an intense degree all the known factors of species-making. On the one hand, spontaneous variations are more likely to occur through change of food and circumstances ; on the other hand, selective action must be exerted in a very special 
and peculiar way. In the rivers of the lowlands, trout are exposed to the attacks of pike and other savage predaceous fish; here, they need only fear the herons and the angler. In the lowlands, they hide among weed or under banks; here, they are exposed in full sunshine against a light weedless gravelly bottom. In the lowlands, they feed largely upon land worms and other straggling prey; here, they subsist almost entirely upon flies and other winged insects. Accordingly, the qualities which ensure success in the one habitat are quite different from those which ensure success in the other; and as the successful alone survive and propagate their like, it is not surprising that ever since the end of the last ice age-probably no more than some 70,000 years since-as many as eight or ten separate species of mountain-tarn trout should have been evolved in the British Isles alone.

At the same time, it must be borne in mind that while the isolated colonies in these 
little pools have been slowly altering in one direction under the influence of changed conditions and of a more specialised natural selection, the trout of the lowland rivers have -also doubtless been altering in another direction, under the influence of stronger and fiercer competition. The divergence has been double-sided. We must not take the existing lowland trout for a true representative of the common ancestor, and then measure the deviations of this Llyn Gwernant species by that fallacious standard. If ever a young Llyn Gwernant troutlet, in his desire to see the world, leaps the cascades and ventures down into the river, we may be sure he is snapped up bodily by the first pike that meets him; and that is why this rare species has never spread elscwhere. It is only suited to its own habitat; while the common speckled trout of our rivers are adapted to avoid the various greater dangers of their wider world. If we were to compare together all the special mountain trout of the various Welsh and 
Scotch pools, we should probably find that they all agreed in certain broad characteristics which really re-called the original ancestor more fully than the lowland species recalls him. Only these broad characteristics would be largely masked by the special adaptation of the Loch Stennis trout to the pools of Orkney, and of the Llyn Gwernant species to this particular petty Welsh tarn. 


\section{XVIII.}

WILD THYME.

EXCEPT only Scotch heather-that artistic saving grace in our cold grey Northern hills-I know no English plant which produces such brilliant masses of warm colour on a large scale as the little creeping blossoms of the wild thyme. Here on the hillside, between the jagged and jutting edges of rock, the rich black peaty soil is thickly overgrown with tangled patches of its purple flowers; and the sweet scent and the hum of bees mingle in one's mind with that indefinite literary charm derived from faint suggestions of Puck and Oberon to make this mellow autumn afternoon seem for a moment like a little bit 
of Shakespeare's dreamland. For wild thyme is essentially a bee-flower, and wherever it grows you may see the big burly humble-bees and the slenderer little hive workers, with their honey-bags well distended and their legs clogged by pollen, bustling about eagerly from head to head of the tempting blossoms. The whole labiate kind, to which wild thyme belongs, has been developed in strict correlation with the shape and habits of bees. No other family of plants (except the orchids) has flowers more curiously shaped than those of the salvias and horehounds ; certainly no other family is so noticeable for sweet or aromatic scents as this, which includes the sage, mint, thyme, basil, rosemary, balm, hyssop, patchouli, marjoram, lavender, and catmint. Such scents are always due to the selective action of the higher insects, and are found only in the flowers which they most frequent. Indeed, we know geologically of no labiates before the late tertiary period, which is just the time when highly-developed bees began to present 
themselves. The honey-seekers and the honey-producers seem to have evolved side by side for one another's mutual benefit.

There is another noteworthy point, however, about the wild thyme which marks it off from the rest of the labiates in one respect as a very special and peculiar form. If you pick a little spray from the clump that covers this hollow in the rock basin you will see that it has some small unopened buds at the top end of the spike, some full-blown blossoms half-way down, and some overblown flowercups on the stalk below. Now, if you look into these overblown cups you will see that they are apparently very shallow-much more shallow than in this bit of hemp-nettle -another common labiate-which I have picked for comparison with them. Moreover, the cup in the hemp-nettle is filled by four little flattened nuts or seeds, while that of the thyme seems to be empty. Of course the object of all flowering is the production of seeds ; and one might at first sight be tempted 
to suppose that the thyme was quite barren, and so failed entirely of its function in life. But if you cut open the calyx of the overblown thyme-blossoms with a sharp penknife you will find that the barrenness is only pretended, not real. What seems to be the bottom of the calyx is really a thick wall of interlacing hairs; and beneath this wall lie four little nuts, just like those of the hempnettle, only on a smaller scale. If, again, you cut open one of the full-blown blossoms, you will find that these hairs may be seen inside the calyx even while the corolla tube is entire, but they are then pressed back against the throat by the tube itself. As soon, however, as the tube and the corolla wither and fall out-which they do at once when they have played their part in the economy of the plant by inducing a bee to visit and fertilise it-the little hairs, relieved of this pressure, jump out by their own elasticity, and completely obstruct the entrance to the calyx, thus forming, as it were, a false bottom. 
Unless you were in the secret you would take it for granted that the calyx was empty, and had either shed its nutlets or else never contained any at all.

Now this is exactly the impression which the plant wishes to produce; or, to "put it more correctly, it is because the plant has thus succeeded in producing a wrong impression on the minds of birds and insects that it has acquired this false bottom of interlacing hairs, and has so survived in the struggle for existence. Why the wild thyme finds such deception pay is simple enough to understand. Here close at hand is a bit of mouseear chickweed, well in fruit. The plant is covered by numbers of little capsules, each containing a dozen seeds or more; but if you cut them open, you will find almost every capsule, in this district at least, has been invaded by a perfect plague of little red or orange worms, which devour most of the seeds before they arrive at maturity. Hence the chickweed, being unprotected against 
their depredations, is obliged to produce an enormous quantity of seeds, at a ruinous cost to its constitution, most of which get eaten up without doing any good at all to the species. For aught we know to the contrary, these red worms may be now in course of exterminating the chickweed, much as the Colorado beetle would exterminate the potato, or as the phylloxera would exterminate the vine, if we did not invent all kinds of Paris greens and institute all sorts of national quarantines to check their triumphal progress. Every now and then some new insect pest in this way sweeps across a continent, killing or threatening to kill some particular species; and when the plant which it attacks is one useful to man we note and chronicle its advance, which we are often successful in arresting; but when the invasion is only directed against a common weed none but naturalists observe its course, and even they can hardly obtain the proper data for estimating its advance, since nobody keeps a 
record of the acreage under knotweed, or the average yearly yield of the goosefoot crop.

Now if, in such a case, any particular plants of the infested species happen to be protected against the intruder by some small peculiarity of structure, they will survive when their fellows perish, and a new species will tend to be set up, possessing the peculiarity which saved the lives of its ancestors. This, or something like this, is what must have happened to the wild thyme and its close relative the marjoram. They found themselves exposed to some special danger which did not threaten the other and larger labiates; and those alone survived which possessed in a nascent form this fringe of hairs concealing the nuts within. Perhaps the selective agency at work was some small bird or insect which could not tackle the larger and harder nutlets of the dead-nettle and the stachys : perhaps it was some creeping worm against which the stiff and prickly stem hairs of the bigger species formed an efficient 
chevaux de frise. At any rate, the hairy fringe in the throat of the calyx of the wild thyme protected its seeds against some danger to which they would otherwise have been exposed; and only those individuals which possessed it finally survived in the struggle for life.

Such special means of protection for ripening fruits or seeds are common enough in nature; but it is curious how vast is the variety of form or device which they assume. Here, for instance, in the bit of boggy land formed by the little rill on its way through the rock basin, another small labiate grows in profusion, the lesser skullcap. Now skullcap takes its name from a peculiarity of its own, which answers in a different way just the same purpose as the interlacing hairs of the wild thyme. On the back of the calyx is a large scale or raised spur, which looks something like the shade of an old-fashioned cap while the flower is in full bloom; but as soon as the corolla has withered, the upper 
lip of the calyx closes over the four nutlets, while this scale assumes its place and so produces the effect of an empty seed-vessel. Any prying bird or insect which looked into such a calyx on its foraging expeditions would be sure to conclude that it had already shed its seeds, and so go off to another plant. Thus in two closely related species we see two totally different plans for securing the self-same end. In one group, the originally accidental presence of a few hairs in the throat gave rise to a new departure in one direction; in another group, the habit of closing over the nuts, with perhaps the rudiment of a scale on the back, gave rise to a different departure in another direction.

The hop supplies us with a very similar case in a widely unlike family of plants. Hops, as Kentish farmers know only too well, are liable to attack from 'the fly' and many other enemies. To protect their seeds, the hope of future generations, from these marauders, the vines have hit out the plan 
of producing hops, that is to say, little leafy imbricated cones which cover the blossoms. After flowering, the scales of the cone become much enlarged, and quite conceal the small seed-like fruits; and it is these protective organs which we Northern nations apply to our own uses, corrupting corn with them, as Tacitus naïvely remarks, in quandam vini similitudinem. Indeed, it may be said roughly that human beings invariably defeat the original intention of plants, by cultivating and selecting them in order to eat up those very seeds, fruits, roots, and tubers which the plants themselves had richly stored with starches, albumens, and other food-stuffs for the use of themselves or their descendants. We plunder the storehouses which the species designed for its own benefit; yet by saving some for seed and sowing it in fitly prepared places we keep up the life of the species far more effectually than it could ever have been kept up had the plant been left entirely to its own devices. 


\section{XIX.}

THE DONKEY'S ANCESTORS.

$\mathrm{HE}$ is a dear shaggy old donkey, with the true pathetic donkey eyes, and that wonderful donkey power of making himself perfectly happy on a bare rocky hillside, upon four sprouting thistles, a bit of prickly carline, and three square yards of wet turf at the outcrop of the little spring, overgrown with rank bogasphodel and stringy goose-grass. Given this delicious pabulum, with five minutes' total freedom from beating or bullying, and your shaggy donkey is in his seventh heaven. That is what constitutes the true poetry and pathos of his life. I am not ashamed to side with Coleridge on that question, in spite of the sneers in 'English Bards,' or in 'Rejected 
Addresses.' A donkey is a really pathetic and sympathy-rousing figure in nature, because, with all his hard blows and buffeting, he retains to the last a brave cheery philosophy which teaches him to take an optimistic view of things whenever it is possible-a sort of monochronic hedonism under difficulties-that contrasts favourably with the despondent Hartmannic theories of the universe so much in favour with well-fed and bushy-bearded German professors. Schopenhauer's demonstrations trouble him not: Mr. Mallock's doubts as to the abstract desirability of existence enter not into his thoughtful pate: let him but loose from his hard day's work to a dinner of herbs of the toughest, and he forgets the pessimistic problem forthwith in the delights of freedom and the exquisite pungency of his tuft of thistle head. Shall we not strive to make life a little easier in the future for such a patient, hardworking, brave-hearted, indomitable little philosopher as this? 
How, indeed, could the common and universal notions about the stupidity of donkeys ever have originated? A sheep, if you will, is stupid, and so is a rabbit ; but I doubt whether there is really in all nature a more careful, sensible, intelligent, and wideminded brute than the common donkey. I have always admired the genuine penetration of those South American mountaineers who told Mr. Darwin that they would give him the 'most rational' mule on which to cross a dangerous pass of the Andes. They knew the capacities of the mule; and I have no doubt they knew those of the donkey too. The fact is, every one who has watched donkeys closely must have noticed innumerable proofs of their unusual mental gifts. They stand, with the horse, the elephant, the camel, and the monkeys, at the head of the animal world, intellectually considered. (Dogs of course I put out of consideration, as products of direct human teaching.) But donkeys are the final flower of long ages of native evolu- 
tion, the natural head and crown of one great line of mammalian development. To doubt their intelligence is to impugn the whole conduct of nature, to upset the entire system of evolutionary psychology off-hand. Donkeys cannot help being clever, because they are the final survivors in the struggle for existence in one of the most specialised, most highly developed, and most dominant mammalian stocks. They do not represent mere stranded and struggling relics of older types, like the very silly kangaroos, and ant-eaters, and hedgehogs, which drag on a miserable existence behind the times in out-of-the-way holes and corners of the earth : they are one of the finest developments of one of the most successful branches of the great progressive ungulate tribe. I feel a genuine respect for every donkey I meet when I remember that it was the mere accidental possession of an opposable thumb that gave my ancestors a start over his in the race for the inheritance 
of the earth towards the very close of the tertiary period.

Of course everybody knows the wonderful pedigree of the horse and donkey family, which has been discovered imprinted upon the later formations of America by Professor Marsh, and reconstructed for us in full by Professor. Huxley. The horses are an extremely aberrant form of the ungulate tribe, and their very earliest recognisable ancestor must have had some points of resemblance with the tapirs, some with the pigs, some with the deer-nay, some even with the prototype of the lemurs and of man himself. In the lowest eocene beds of New Mexico, Professor Marsh has found the first shadowy forerunner of my donkey-an equine quadruped which he has appropriately called eohippus, with five toes to each hind foot, and probably to each forefoot as well. Already, however, this very vague progenitor of the horse family had begun to develop 
towards the distinctive peculiarity of his race -the solid hoof, adapted to free scouring over open grass-grown plains; for one of his five toes is, even at this early period, only in a rudimentary condition. In the higher eocenes of Wyoming and Utah we get a rather more horse-like creature, orohippus, as big as a fox, with four toes to his front feet and three to his hind feet. Then, only about a million years or so later, in the miocene of Oregon and Nebraska, we find two more specialised equine animals, miohippus and mesohippus, as big as a sheep, with three hoofed toes on the front feet, of which the middle one is distinctly the largest, being, in fact, the forerunner of the one final hoof in our own horses. In the pliocene, again, we come upon the bones of hipparion and protohippus, as big as this donkey, with one stout middle toe, much like our modern horse's hoof, and a lateral one on each side which does not reach to the ground. Side by side with these very horse-like forms occurs 
another even more specialised type, pliohippus, in which the lateral toes have become reduced to mere splint-bones, as in our existing species. Here, we have all often been toid, we have probably preserved for us several distinct steps in the evolution of our horses and donkeys. One solid hoof on each foot gives unarmed herbivorous animals of their peculiar habits the best possible chance in the struggle for life; and so towards the development of this one hoof they have been slowly verging ever since eocene times, by the gradual enlargement of the central toe, and the gradual suppression of all the rest. They have no horns like the bison and the buffalo; but by their swiftness and sureness of foot wild horses are able easily to hold their own against all carnivornus enemies on the grassy pampas of South America, as zebras do on the great South African plateau, and onagers on the broad steppes of Central Asia.

Most people, however, do not know that 
paripassu with this development of a special form of hoof adapted to the free roaming existence of the horse tribe there has gone on a constant increase in the relative size and weight of the brain. Our comparative anatomists as a rule naturally attach most importance to the development of the bony skeleton, and especially of those parts which are most characteristic of families and genera. Psychology is a subject that interests them comparatively little. Hence we lay-readers are apt to get rather surfeited with descriptions of changes in the supra-condyloid foramen or the lateral ethmoid, about which the world at large is culpably indifferent; while we hear hardly anything as to the evidences of mental development, about which the world at large feels a much more genuine interest. As a matter of fact, in the pedigree of the horse and the donkey there is abundant proof of such progress. The brain of the evolving horse tribe goes on increasing (as we judge from the skulls) with 
every advance in structure through tertiary times, not only absolutely as the whole animal grows bigger, but relatively also in proportion to the other parts. Indeed, there has been a regular increase in intelligence and brain-power among all the mammalia from the moment of their first appearance upon the earth till the present time.

Such an increase naturally results from the very conditions of evolution. Not only the strongest and the physically best adapted have survived in the long run, but the cleverest and the shiftiest as well. All very early mainmals, discovered sparsely in the secondary formations, have extremely small and ill-developed brains. All surviving isolated archaic forms, preserved in special and long insulated areas, far from the fierce competition of higher types, as is the case with the marsupials of Australia, the low lemuroid animals of Madagascar, and the edentates of South America, have brains hardly better than these primitive species. 
All ancient types which still linger on as burrowers or nocturnal prowlers in the great continents, like our own moles and shrews and hedgehogs, have also a very low grade of intelligence, and a very poorly developed brain. But as we rise toward the summit of each great specialised and differentiated line of modern mammals, we find a constant increase in intelligence and brain-power, exactly analogous to that which we can trace historically in the horse tribe. The central and least developed forms, like the rodents and still more the insectivores, are comparatively stupid and helpless; but the highly adapted creatures which represent the final outcome of the main divergent branches, such as the ungulates, the carnivores, and the quadrumana, are all remarkable for their exceptional intelligence. Of these crowning species, the horse and the donkey stand at the head of their own line, just as man stands at the head of the quadrumana, or as the elephant and the tiger stand at the head of 
their special genealogical trees. So that the donkey really cannot well avoid being an extremely clever brute. Not quite so clever, to be sure, as the higher monkeys and the elephants; for, as Mr. Herbert Spencer has pointed out, the opposable thumb and the highly mobile trunk with its tactile appendage give these creatures an exceptional chance of grasping an object all round, and so of thoroughly learning its physical properties, which has put them intellectually in the very front rank of the animal world; but in the carnivores, the ruminants, and the horse tribe, a very delicate sense of smell seems almost to make up for the want of a special grasping organ. At any rate the leading members of these groups - the cats, bears, camels, deer, bison, horse, and donkey-are all of them conspicuous among their compeers for the relatively high quality of their intellectual gifts. 
XX.

BESIDE THE CROMLECH.

ON the long spur where the path loses itself among bracken and heather, just below the summit of Mynydd Mawr, I met an Ancient Briton, from whom I tried to learn the way to the cromlech: Unfortunately, my Ancient Briton 'had not the English,' and so failed to comprehend the questions I put to him. But, by mustering all my stock of Welsh in a supreme effort, I managed at last to make him understand what it was that I wanted. 'Oh, ay,' hẻ says, in his native Cymric, politely swallowing down his rising smile at my imperfect $l l$ 's and ch's, 'You mean the Fairy's Grave. Cross past the llyn and up 
the ledge of Crib Goch, and you'll find it on the very crest of Mynydd.' I will not assert that I fully understood him in every word, but that was certainly the gist of his directions, eked out by a good deal of gesture and pantomime; and, at any rate, here I am at last, stretched out at full length under the shadow of the great monoliths and looking across the bay, whitened by the foam of Sarn Badrig, to the long clear-cut blue range of the Carnarvonshire mountains. The sky is cloudless and the horizon very free from mist, so that I am well rewarded for my pains; for I can see the whole peninsula from Snowdon on to Braich-y-Pwll rising and sinking in hill or lowland, and at the very end of all, Bardsey, the Isle of Bards, stands square and solid against the sky-line, with a solitary ship under full sail showing in the very centre of the sound, and the Irish Sea stretching away to southward, distinct and blue as far as the eye can reach.

The cromlech itself is a fine specimen of 
a megalithic structure, piled up of four large boulders from the neighbouring hillside, and but little squared or hewn by artificial means. The boulders do not belong to the same Cambrian rock as the underlying hill; they are fragments of Snowdonian granite, transported hither by the glaciers of the great ice age, which scratched the grcoves and furrows on the naked limestone of the mountain itself. I can trace these grooves all around me on every hand; and indeed the bossed and rounded surface of all the shoulders would in itself suffice to suggest glacial action immediately to any geological eye. Similar markings occur on the sides of the three upright stones in the cromlech, and on the under front of the table-stone which lies across them; but here and there the original striated surface has been cut away by the. rude tools of the primitive cromlech builders, in order roughly to shape the irregular masses for their present position. For of course cromlechs, though very ancient from 
the historical point of view, are quite modern in the geological or even the anthropological estimate. They have been erected a long way on the hither side of the glacial epoch. There were men in Britain before the last ice age, and they have left their memorials in the rough chipped flint implements of the drift and on the hardened floor of caves; but every trace of their presence has of course been planed off the actual surface of the country by the great sheets of ice which, during the last glaciation, ground down the whole face of England into bare undulating folds of naked rock. The prehistoric monuments which we now find on the surface of the land, like this Welsh cromlech or the numerous barrows of our English downs, belong to a much later race, as one can see at once from the very fact that they are so often built up of glacial boulders. Indeed, the earlier preglacial men were mere hunting savages of the rudest type, wholly incapable of co-operation for works such as these; so 
that even if the ice had not swept away every trace of them, as it has now swept over the whole face of Greenland, we should still have few monuments of such early date save only the angular hatchets of the drift and the shapelier bone harpoons of the whale hunting cave-men.

Originally, this cromlech must have been covered with a barrow. It formed, indeed, the central chamber of a neolithic tomb; and over it the earth was once heaped up in a great and conspicuous pile. In England, as a rule, the barrows still survive, especially in all the south-eastern plain and the lesser hills or downs. But in Wales and Cornwall, and in the more mountainous regions generally, where soil is scanty and denuding agents act more rapidly, the barrows have oftener been washed away by rain and torrents or slowly crumbled down by sun and wind. That, no doubt, is partly the reason why people generally believe that 'Druidical remains,' as they choose to call them, are specially 
frequent in these Keltic regions. It seems natural enough to suppose that ancient British monuments should be carefully preserved in such outlying spots as these where the Ancient Britons still survive in almost unmixed purity. But, as a matter of fact, the cromlechs are really less preserved here than elsewhere, because their barrows have mostly been washed away, and the body within has long since disappeared. The best preserved cromlechs are, of course, those which you cannot see at all, because they are still covered with their enclosing mound of earth and still contain the bones and relics of the dead man within them. It is the desecrated tomb that we call a Druidical monument; the undesecrated we only describe as a prehistoric barrow.

There can be very little doubt that this cromlech, like all others, was once upon a time the tomb of an early chieftain. From the general character of its workmanship, and the very slight extent to which the stones have 
been dressed, I feel pretty confident that it must belong rather to the neolithic than to the bronze age. Hither, some day five thousand years since-perhaps ten thousand for all that science can say-a crowd of brownskinned, short-statured tribesmen bore up the dead body of their chief from the village in the clearing on the little stream below. Here with wooden levers and round logs for rollers they toilfully brought together by sheer force of straining sinews these four great ice-worn boulders which lay scattered upon the slope around. On the crest of Mynydd Mawr they hewed them into rough symmetry, and built them into a rude imitation of the royal hut, first placing the three uprights in position, and then prising up the flat roofing-stone with their $\log$ rollers over an inclined plane of loose earth. In the hut thus formed they placed the dead body of their chief, with his weapons, his ornaments, and his household goods, that his ghost might eat, drink, and fight in the world of ghosts as it had done in 
the valley below. Then they piled up the great mound of earth above it, to keep the body safe from beasts or birds ; and around the fresh heap they performed I know not what barbaric orgies of dancing and sacrifice and human massacres. Perhaps the wives and slaves of the dead man were slain and buried with him, to attend him in the other world; perhaps the blood of human victims was poured over the new-made grave as an offering to the thirsty ghost. Sitting in this peaceful industrial nineteenth century on the dry heather under the shadow of these picturesque old stones, one can hardly realise what nameless horrors they may not have witnessed on the day when the neolithic dwellers in the Llanfair valley first raised them above the summit of Mynydd Mawr. We think of them only under the softening and romantic influence of time; we look upon their lichen-covered surface through the tinged halo of poetical imagination; they are to us the hoary remnants of our fore- 
fathers' world, the titanic, archaic, immemorial temples of a forgotten creed. We do not remember how terrible and sickening were the realities of which these grey and yellowstained granite bosses are the sole remaining vouchers. Time has turned the relics of some Dahomey custom into a pretty antiquated landmark and a romantic spot for holding a picnic.

Since then the rain has washed down every particle of soil that formerly covered the dead chieftain's grave. But still the memory of what it all once meant has lived on uninterruptedly in the minds of the Ancient Britons - around the spot. While the doctors of the eighteenth century were talking learned nonsense about Druidical temples and Arkite worship, the Welsh peasants of Mynydd Mawr were speaking correctly every day of the Fairy's Grave. For fairies and goblins and all such Keltic superstitions are mainly based upon stories about the ghosts of these neolithic people, whom the Keltic Welsh 
overcame and enslaved. But they would not touch the graves where lay the chieftains of the conquered folk, lest harm should come upon them for the desecration. Many of the neolithic people lived on as serfs under the Kelts, and much of their blood may be noted in the Llanfair villagers at the present day. The Briton who told me the road here was himself indeed much more than an Ancient Briton; he was partly at least one of the Ancientest Britons, a dark-haired, squat, brown-skinned man, of the regular longheaded Euskarian type. Professor Rhys has heard men taunted even now at Carnarvon with being the descendants of fairies; that is to say, I take it, with being members of the servile race; just as in America, supposing blacks and whites to have amalgamated for centuries, it might still be a term? of insult to call a man a nigger. When we remember that in all popular tradition the fairies are said to live inside green grass-grown hills, and that their names are always connected 
with the prehistoric neolithic monuments of each particular district, a cromlech such as this, the Fairy's Grave, gains in our eyes a double interest. For while on the one hand it is the undoubted burial-place of a Euskarian chief, on the other hand it is the almost certain birthplace of a Keltic fairy tradition. 


\section{XXI.}

THE FALL OF THE LEAF.

Already the trees on the hillside are beginning to assume their autumnal tints. Down in the valley, it is true, beside the artificial water in the park, the oaks, the willows, and the ash trees are still quite green; but higher up among the slopes, where the wind beats harder and the nights even now begin to grow chilly, the limes and chestnuts have put on their first pale streaks of yellow, the beeches have turned in places to a rich brown, and the mountain ashes are faintly purpling against the glowing bunches of their scarlet berries. On all the deciduous trees, indeed, one can see that the living protoplasm is just 
beginning to withdraw from the foliage into the permanent tissues, leaving only those beautiful minor principles iwhose deficient vitality produces the lovely colours of autumn leaves. It is the fashion to say that our English woodlands cannot compare in this respect with American or Canadian forests; and, no doubt, if we look only at the general effect in the two hemispheres the trite remark is true enough. America has undeniably one tree-the maple-whose foliage fades under that particular climate into graduated tints of crimson, scarlet, orange, yellow, and pale green, in a way that no European leaves have learned to imitate; and the maples are often abundant enough to give a general tone of brilliant colouring to an entire landscape such as we seldom see in our damper and mistier England. Besides, the change from summer to autumn comes on more rapidly there than with us: a few consecutive nights of dry, clear frost alter the whole face of nature, as if by magic, from green to gold and purple, in 
a fashion which would be impossible with our slow, long-drawn, changeable seasons. Yet, in spite of all this, I am not prepared to admit that even on the St. Lawrence or the Hudson you can often see anything more brilliant in its way than the yearly September display on our Thames about Nuneham and Pangbourne, or the Founder's Tower at Magdalen, clad from pinnacle to base in crimson Virginia creeper during the first fortnight of October term. Such outbursts of pure warm colour are certainly rarer here than in America; but when once seen they enable one at least to realise, if my memory serves me right, what Canadian woodlands are like when the maples are set ablaze with red and orange in the mellow evenings of that too rare season, a successful Indian summer.

It is a curious phenomenon, this annual fall of all the leaves from almost all the trees in northern climates; and yet use has so dulled us to its strangeness that we seldom 
even think about its origin or meaning in any way. Indeed, until certain late investigations of the tertiary floras by M. Saporta, Mr. Starkie Gardiner, and others, it is doubtful whether anybody had ever asked himself any question upon the subject at all. But these investigations have shown pretty clearly that deciduous trees are quite a modern novelty upon our planet, things of the last two hundred millennia or so, entirely due to the immense cooling of the earth's surface which began in the early tertiary period and culminated in the great glacial epoch. They are a special product of hard times at the Pole, like the white bears, the woolly rhinoceros, the mammoth, and the snow-buntings. In the tropics all the trees are evergreens, or at least suffer no regular periodical loss of their foliage; but in the north we have few native evergreens except the pines and firs, with their needle-like leaves: and the two or three hardy, broad-leaved exotic evergreens cultivated in our gardens or shrubberies, such as 
the rhododendrons, the laurels, and the bay trees, together with our own smaller holly, box, and privet, hardly suffice to convey a notion of the great southern forest trees, clad all the year round in thick green, such as the mangoes, the star-apples, and the sand-boxes. Up to the beginning of the tertiary period, however, large evergreens of what is now the tropical type covered the whole of the world, as far as the very Poles themselves. Greenland and Spitzbergen then supported huge forests of the same general character as those which now spread over Brazil and the Malay Archipelago. But from the first dawn of the eocene onward, some combination of astronomical and geographical causes, such as those suggested by Dr. Croll and Mr. A. R. Wallace, began to produce a general chilling of the temperature at either Pole. Perhaps the effect was wholly due, as Dr. Croll believes, to the eccentricity of the earth's orbit and the precession of the equinoxes; perhaps it was further aided, as Mr. Wallace suggests, 
by the elevation of great mountain ranges about the polar regions, which became nurseries for immense glaciers, and so supplemented the natural chilling due to the cosmical cycles. At any rate, whatever theory we may adopt for its explanation, the fact itself remains certain that from the eocene age up to the glacial epoch the climate of the earth grew steadily colder, the change being of course most marked at either Pole, and least noticeable in the equatorial district.

Concomitantly with the steady decrease of temperature thus forced upon the earth, a new forest vegetation developed itself in adaptation to the altered circumstances. This modern cold-weather flora of course first showed its face in the polar regions, or, to speak more correctly, about the North Pole. Here the fresh conditions first made themselves felt, and here all the familiar trees of modern English woodlands had their generic origin. In the eocene days the arctic flora was still of a temperate or even sub-tropical 
aspect. But in the miocene age this temperate arctic flora was driven southward by the advancing cold, while a more strictly northern type of vegetation began to show itself among the hardy survivors which could accommodate themselves to the chillier winters of the new epoch. In the pliocene period, once more, the arctic miocene trees invaded northern and central Europe, and a still colder type appeared around the Poles. Finally, with the pleistocene age, masses of ice began to occupy the North Pole itself, and drove even the hardiest and most arctic vegetation down to the Mediterranean basin, while England and half Germany were covered by the enormous sheet of permanent glaciers.

Now though the conifers, with their tough capillary leaves, did not suffer largely from the change, the evergreen tropical trees were clearly quite unfitted for conditions such as these. Their big leaves could do no serious work in the way of assimilating carbon from 
the atmosphere in the cold and gloom of northern winters; and the wind] would only tear them off by thousands and waste the chlorophyll and starches laid up in their tissues. To meet this difficulty the modern deciduous oaks, ashes, and elms were developed. These trees do not merely allow their leaves to fall off with the wind, but they make actual provision for such a contingency beforehand. Each leaf-stalk is provided with a row of special empty cells, which are so constructed that as soon as the leaves begin to die they rot away, and accordingly let the leaf fall readily, leaving a clean, dry scar, instead of waiting till some violent storm wrenches them off, tearing the living tissues and wasting the sap by bleeding. Moreover, when autumn comes on, the living and utilisable material in each leaf is first withdrawn into the bark and branches, where it is stored up during the winter in order to feed the young leaf-buds in the succeeding spring; and then the row of specialised division-cells 
begins to warp, and lets the now useless skeleton of the blade drop off with the wind. Those large-leaved trees which thus learned to economise their stock of food-stuffs were alone able to compete advantageously with the wiry and tough-skinned pines or firs; and thus many distinct families of forest trees, such as the maples, the oak and beech tribe, the elms, and the apple group, none of which are at all related to one another, have quite separately hit out the very same idea. Those which did not hit it out went to the wall; and indeed our existing northern forest flora represents, as it were, a mere fragment of the original northern vegetation - the few scattered species here and there among a vast number which managed to adapt themselves to the new and ungenial conditions of the northern zone.

It is to this withdrawal of the green colouring matter and the other living principles from the dying leaves that we owe the tints of autumn, as Mr. Sorby has carefully 
and minutely demonstrated. But it is a suggestive and striking fact that hues like these should exist always unseen in the very structure of the living plant, ready to be developed at any time by proper selective or accidental circumstances. Some of the colours are produced by the oxidation of the green chlorophyll in person; others are actually present in the green leaf itself, though completely masked during the period of vigour by the preponderance of the natural pigment, which owes its colour to a due admixture of them all. When we consider, however, that colours like these lie ready and waiting in the tissues of every plant, showing themselves wherever chlorophyll is not present in its most active form, alike in the young leaves or sprouting shoots of spring and in the dying foliage of autumn, it is easier to understand how the beautiful and brilliant petals of flowers have been developed by the selective action of insects. The red and orange and 


$$
\text { THE FALL OF THE LEAF. }
$$

blue pigments were potentially there already; the insects' part was only to seize upon and favour them whenever special circumstances happened to bring them out into visible actuality. 


\section{XXII.}

THE FALL OF THE YEAR.

UP on the downs to-day the view is dreary and gloomy enough. A grey mist hangs over the horizon to seaward, while inland the hollow combes and rounded shoulders of the distant chalk range hardly stand out at all through the foggy air. Sunlight throws up their varied contour with splendid perspective depths of black shadow; but in dull wintry weather like this, the outline merges into a single, unbroken leaden-blue line against the white background of the sky. There can be no denying that chill October is really upon us. Yet even now a few patches of colour still remain-some golden heads of the 
autumnal hawkbit on the open, some straggling bushes of the dwarf furze upon the glen-sides, and a mass of rich foxy-brown bracken among the tumbled and uneven rockery of the undercliff. The season is not quite so far advanced here on the south coast as it was a few days since among the dry heather-clad hills and yellow autumn woods of North Wales. Every twenty miles southward tells at this season of the year, and so the passion-flowers are even now in blossom down here on the trellis-work of the cottage, with its southerly aspect, while the trees and creepers are fast growing leafless among the windy hills of the north and the midlands.

It was Buffon, that half-unconscious predecessor of our modern evolutionists, who first pointed out the true importance of these zones of climate, from pole to equator, in the history of life upon the earth. For Buffon, with all his contempt for systematic classification and for accurate scientific knowledge, was a man of that wide philosophic grasp and that 
intuitive insight which are often more valuable after all than any amount of capacity for remembering dry detail; and he saw many points accordingly which were hidden from the wise and prudent artificial systematists of his time. Organic life, he remarked, must have begun at the Poles. For on the surface of an incandescent planet the Poles would be the first part to cool down sufficiently to allow of the conditions under which alone life becomes possible. This pregnant idea has since been fully developed by later naturalists. Not only is it true that life as a whole must have started at its first beginning from the Pole, but we now know that all fresh waves of fauna or flora must in like manner have set out from the self-same point, and occupied the earth by migration in circumpolar zones. Moreover, the great centre of all life was in all probability the North Pole alone, not the South; for since Mr. Wallace's luminous researches on the geographical distribution of animals, it has become almost 
certain that our existing continents have been steadily growing up for a vast period of time, and that our existing oceans have been oceans and nothing else ever since the aqueous vapour of our planet first condensed and cooled into water. Hence it follows that the South Pole has always been isolated in the midst of an enormous stretch of ocean, while the North Pole has always been the point from which the great land masses of Europe, Asia, Africa, and America have radiated southward. In both hemispheres we find the land widening out towards the North Pole, but tapering away towards the South; and we know that South America and South Africa were till recently isolated outliers of their respective continents, while Australia remains an isolated outlier of Asia to the present day. Thus, every great wave of animal or plant population must have set out always from the North Pole, must have spread southward in concentric circles, and must have but slowly reached the outlying 
southern extremities. Hence, generally speaking, we may expect to find the newest and most modern types in the great northern continents, and the oldest and most archaic types in the tapering southerı peninsulas and islands.

The fact is, however, it is now alitumn with the whole of our planet, and the last great cold spell from which the northern hemisphere suffered - the glacial epoch-has somewhat interfered with the literal truth of this rough generalisation. Climatically speaking, our earth has seen its best days. We are now growing colder from age to age, and we may look forward in the distant future to an absolute winter extending over the whole globe, when its surface will be as dead and changeless as that of the moon actually is before our own eyes. Life, indeed, viewed cosmically, is but a superficial phenomenon produced by arrested solar radiation on the outer crust of a cooling nebula, and it will disappear some day, from this earth at least, 
amid the universal chilling of an exhausted world. Luckily for us, however-or unluckily if the pessimists will have it so-the winter has not so far really set in, and we are as yet only at the premonitory stage of full autumn. The time is still recent, as astronomers and geologists reckon distance or nearness, when the Poles were warm enough to support a thoroughly tropical type of life. Trees distantly like those of Java and Brazil, animals faintly suggesting those of Central Africa and the Malay Archipelago, then formed the fauna and flora of the extreme north. But just as the Poles had been the earliest part to cool from incandescence into a firm crust, so, when worse times came, they were the earliest part to cool from tropical heat to what we European human beings complacently describe as temperate, and from temperate again to arctic. And as life had first developed at the North Pole, thence to spread southward, so now the new types of life, adapted to the altered conditions, were each first evolved at 
the North Pole, and were each pushed southward one after another, as the cold grew intenser, in concentric rings, so that the arctic fauna in one age becomes the parent of the North European fauna in the next age, of the Mediterranean fauna in the succeeding one, and of the Southern fauna in the epoch after that again. So long as life remained possible at the Pole at all, it was almost absolutely true that the polar plants and animals represented the most modern and most highly evolved types at that moment living upon earth. Spitzbergen, in fact, then led the very van of progressive evolution.

But since the planetary autumn has thoroughly set in, this principle has ceased to be quite true, and has been to some extent reversed by the occurrence of that great premature cold spell, the glacial epoch. Towards the close of the tertiary period, a combination of astronomical and geological causes set up a long interval of intense cold in the northern hemisphere, which made all life impossible, 
not only at the Pole itself, but even as far south as London, Berlin, New York, and Chicago. During that interval, all living things were necessarily driven towards the sub-tropical and equatorial regions; and the middle of the earth thus became for a while the seat of the richest and most advanced fauna and flora. Some seventy or eighty thousand years since, if we may trust Dr. Croll, backed by the almost unanimous opinion of the greatest scientific authorities, these unfavourable astronomical conditions ended, and the vast glacial sheet cleared away from the face of the northern hemisphere, at least below the latitude of Greenland. But, as Mr. Wallace believes, the geological conditions remained unaltered; and so, instead of the Pole becoming once more habitable, it still continues to be enveloped in perpetual snow. From that time forward, the exiled plants and animals, which had been driven south by the advancing cold, have begun to migrate northward once more, and to re- 
occupy the deserted plains of temperate Asia and America.

In the eastern hemisphere, however, the conditions have been unfavourable to their rapid northward progress. In Asia, the great central region is occupied by the snowy mountain ranges of the Himalayas and the Hindu Kush, and by the high table-land of Thibet, which cut off the cold Siberian plains from the rich fauna and flora of the Indian region; in Europe, the Mediterranean and the Caucasus similarly divide us from Africa, which is itself cut almost in two, biologically speaking, by the practically lifeless district of Sahara. Hence it is only in America that the fauna and flora have been free to make their way back unimpeded from Carolina and Georgia to New England and the St. Lawrence basin. Even here, the re-peopling has been far from complete; while in isolated portions of Europe, like Great Britain, and still more markedly Ireland, where the fauna and flora had hardly time to penetrate before 
the submergence which turned them into islands, the comparative poverty of life is very noticeable. Nevertheless, the temperate types have everywhere driven out the polar species which preceded them, except on the very summits of the principal mountains. Near the top of Mount Washington, the highest peak in the Eastern States, there linger even now some few butterflies of a species which is not found again till we reach the arctic regions. Their ancestors were stranded there by the receding glaciers, when all the rest of their kind were driven northwards; and there alone they have been able to hold their own against the better adapted southern kinds which came to occupy the surrounding country. 



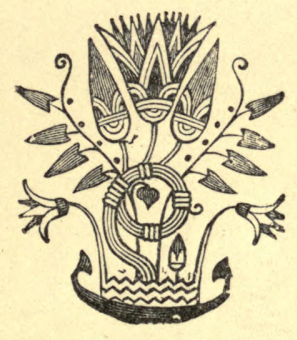





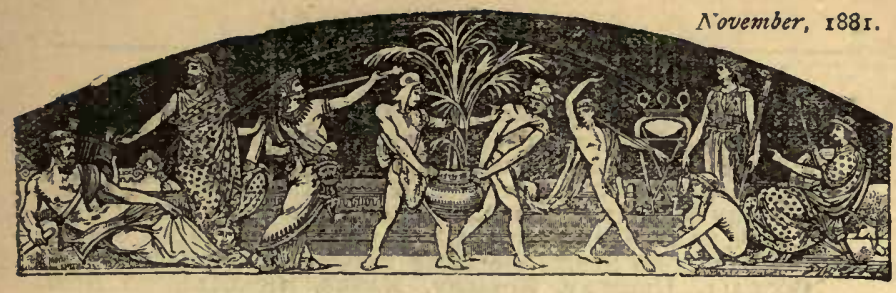

\section{CHATTO \&. WINDUS'S LIST OF BOOKS.}

तase

NEW FINE-ART WORK. Large 4to, bound in buckram, 2Is. Abdication, The; or, Time Tries All.

An Historical Drama. By W. D. ScotT-Moncriefr. With Seven Etchings by John PetTie, R.A., W. Q. ORChaRdSON, R.A., J. MAC WhirTer. A.R.A., Colin HUNTER, R. MACBETH, and TOM GRAHAM.

Crown 8vo, Coloured Frontispiece and Illustrations, cloth gilt, 7s. 6d. Advertising, A History of.

From the Earliest Times. Illustrated by Anecdotes, Curious Speclmens, and Notices of Successful Advertisers. By HENRY SAMPSON.

Crown 8vo, cloth extra, with 639 Illustrations, 7s. $6 d$.

Architectural Styles, A Handbook of.

From the German of A. Rosengarten by W. ColcetT-Sandars.

Crown 8vo, with Portrait and Facsimile, cloth extra, 7s. $6 d$.

Artemus Ward's Works:

The Works of ChARLES FARRER BROWNE, better known as ARTEMUS

WARD. With Portrait, Facsimile of Handwriting, \&c.

\section{Crown 8vo, cloth extra, 7s. $6 d$. \\ Bankers, A Handbook of London;}

With some Account of their Predecessors, the Early Goldsmiths : together with Lists of Bankers from 1677 to 1876 . By F. G. HiLton PRICE.

Bardsley (Rev. C. W.), Works by :

English Surnames: Their Sources and Significations. Bg Charles Wareing Bardsley, M.A. Crown 8vo, cloth extra, 7s. 6d.

Curlosities of Puritan Nomenclature. By Charles W. BardsLrv. Crown 8vo, cloth extra, 7s. 6 d.

Crown $8 \mathrm{vo}$, cloth extra, Illustrated, 7s. $6 d$.

Bartholomew Fair, Memcirs of.

By Henry MORLey. New Edition, with One Hundred Illustrations. 
Imperial 4to, cloth extra, gilt and gilt edges, 2 ss. per volume.

Beautiful Pictures by British Artists:

A Gathering of Favourites from our Picture Galleries. In Two Series.

The FirST SERIES including Examples by WILRIE, CONSTABLE,

Turner, Mulready, Landseer, Maclise, E. M. WARD, FEITH,

Sir John Gilbert, Leslie, ANSDell, MARCus Stone, Sir NOel

Paton, Faed, Eyre Crowe, Gavin O'Neil, and Madox Brown.

The SECOND SERIES containing Pictures by ARMrTAge, FAED,

GOODALl, HEMS, EY, HORSLEY, MARKS, NichOlls, Sir NOEL

Paton, Pickersill, G. Smith, Marcus Stone, Solomon,

STRAIGHT, E. M. WARD, and WARREN.

All engraved on Steel in the highest style of Art. Fdited, with

Notices of the Artists, by Sydney ARMYTAgE, M.A.

"This book is well got up, and good engravings by Feens, Lumb Stecks, and others, bring back to us Royal Academy Exhibitions of past years." - Trmrs.

Smail 4 to, green and gold, $6 s .6 d$. ; gilt edges, 7s. $6 d$.

Bechstein's As Pretty as Seven,

And other German Stories. Collected by Ludwig BECHSTErN. IVith Additional Tales by the Brothers GRIMM, and roo Illustrations by RICHTER.

\section{Belgravia for 1882.}

A New Serial Story, entitled "All Sorts and Conditions of Men," written by WALTER BESANT and JAMES RICE, Authors of "ReadyMoney Mortiboy," \&c., and Illustrated by FRED. BARNARD, will be begun in the JANUARY Number of BELGRAVIA; this Number will contain also the First Chapters of a New Novel, entitled "The Admiral's Ward," by Mrs. AlExANDER, Author of "The Wooing o't," \&c.; and the first of a series of Twelve Papers, entitled "About Yorkshire," by KATHARINE S. MACQUOID, illustrated by T, R. MACQUOID.

* The FORTY-FIFTH Volume of BELGRAVIA, elegantly bound in crimson cloth, full gilt side and back, gilt edges, price $75.6 \mathrm{~d}$., is now ready. - Handsome Cases for binding volumes can be had at 25 . eâth.

Belgravia Annual. Demy 8vo, with Illastrations, Is.

With Stories by WILkIE Collins, F. W. ROBINSON, DuTTON COOK, Percy Fitzgerald, J. ARbuthinot Wilson, Henty W. LUCy, D. Christie Murray, James PAyn, and others. [Nov, 10.

Blake (William):

Folio, half-bound boards, India Proofs, 2Is.

Etchings from his Works, By W. B. ScotT. With descriptive Text.

Crown 8vo, cloth extra, gilt, with lllustrations, 7s. $6 d$.

Boccaccio's Decameron;

or, Ten Days' Entertainment. Translated into English, with an Introduction by Thomas Wright, Esq., M.A., F.S.A. With Portrait, and STOTHARD's beautiful Copperplates. 
Demy $8 \mathrm{vo}$, Illustrated, uniform in size for binding. Blackburn's (Henry) Art Handbooks: Academy Notes, 1875. With 40 Illustrations. Is. Academy Notes, 1876. With 107 Illustrations. Is. Academy Notes, 1877. With I43 Illustrations. Is. Acrdemy Notes, 1878. With I50 Illustrations. Is: Academy Notes, 1879. With I46 Illustrations. Is. Academy Notes, 1880. With 126 Illustrations. Is Academy Notes, 1881. With I28 Illustrations. Is. Grosvenor Notes, 1878. With 68 Illustrations. Is. Grosvenor Notes, 1879. With 60 Illustrations. Is. Grosvenor Notes, 1880. With 56 Illustrations. Is. Grosvenor Notes, 1881. With 74 Illustrations. Is. Pictures at the Paris Fichibition, 1878. 8o lllustrations. Is. Piotures at South Kensington. With 7o Illustrations. Is. The English Pictures at the National Gallery. I14 Illusts. I $s_{c}$ The Old Masters at the National Gallery. I 28 Illusts. Is. $6 d$. Academy Notes, 1875-79. Complete in One Volume, with nearly 600 Illustrations in Facsimile. Demy 8vo, cloth limp, 6s.

A Complete Illustrated Catalogue to the National Gallery. With Notes by H. BLACKBURN, and 242 Illusts. Demy 8 vo, cloth limp, 3 s. UNIFORM WITH "ACADEMY NOTES."

Royal Scottish Academy Notes, 1878. II 7 Illustrations. Is. Royal Scottish Academy Notes, 1879. I25 Illustrations, Is. Royal Scottish Acrdemy Notes, 1880. II Illustrations. Is. Royal Scottish Academy Notes, 1381. I04 Illustrations. Is. Glasgow Institute of Fine Arts Notes, 1878. 95 Illusts, Is. Glasgow Institute of Fine Arts Notes, 1879. IOO Illusts. Is. Glasgow Institute of Fine Arts Notes, 1880. I20 Illusts, Is. Glasgow Institute of Fine Arts Notes, 1881. I08 Illusts, Is. Walker Art Gallery Notes, Liverpool, 1878. II2 Illusts. Is. Walker Art Gallery Notes, Liverpool, 1879. 100 Illusts. Is. Walker Art Gallery Notes, Liverpool, 1880. I0o Illusts. Is. Royal Manchester Institution Notes, 1878. 88 Illustrations. Is. Society of Artists Notes, Birmingham, 1878. 95 Illusts. Is. Children of the Great City. By F. W. LAwson. Is.

Bowers' (G.) Hunting Sketches:

Canters in Crampshire. By G. Bowers. I. Gallops from Gorseborougb. III. Scrambles with Scratch Packs. III. Studies with Stag Hounds. Oblong 4to, half-bound boards, 2Is.

Leaves from a Hunting Journal. By G. Bowers. Coloured in facsimile of the originals. Oblong 4to, half-bbund, 2ts.

Brand's Observations on Popular Antiquities, chiefly Illustrating the Origin of our Vulgar Customs, Ceremonies, and Superstitions. With the Additions of Sir HENRY ELLIS. An entirely New and Revised Edition, with fine full-page Illustrations. 


\section{Bret Harte, Works by :}

Bret Harte's Collected Works. Arrangcd and Revised by the Author. Complete in Five Vols., crown 8vo, cloth extra, 6s. each.

Vol. I. Completr Poetical and Dramatic Works. With Steel Piate Portrait, and an Introduction by the Author.

Vol. II. EARLIER PAPERS-Luck of RoARing CAMP, and other Sketches -Bohrmian PaprRs-SPanish and American Legends.

Vol. III. Tales of thr ARgonauts-Eastren SkBtchis.

Vol. IV. GABriel ConroY.

Vol. V. Stories-Condensed Novils, \&c.

The Select Works of Bret Harte, in Prose and Poetry. With Introductory Essay by J. M. BrLLRw, Portrait of the Author, and 50 Illustrations. Crown 8vo, cloth extra, 7s. $6 d$.

An Heiress of Red Dog, and other Storles. By BRET HARTE. Post 8vo, illustrated boards, 2s. ; cloth limp, $2 s .6 d$.

The Twins of Trable Mountain. By BRET HARTE. Fcap. $8 \mathrm{vo}$, picture cover, Is.; crown 8vo, cloth extra, 3s. $6 d$.

The Luok of Roaring Camp, and other Sketches. By BRET HARTE. Post 8vo, illustrated boards, 2s.

Jeff Briggs's Love Story. By BRET HARTr. Fcap, 8vo, picture cover, $1 s$. ; cloth extra, 2s. $6 d$.

Small crown 8vo, cloth extra, gilt, with full-page Portraits, 4s. 6d.

Brewster's (Sir David) Martyrs of Science.

Small crown 8vo, cloth extra, gitt, with Astronomical Plates, 45. 6d. Brewster's (Sir D.) More Worlds than One, the Creed of the Philosopher and the Hope of the Christian.

A HANDSOME GIFT-BOOK.-Small 4to, cloth extra, profusely

Brushwood. Illustrated, $6 s$.

By T. Buchanan READ. Illustrated from Designs by Frederick Dielman.

THE STOTHARD BUNYAN. - - Crown 8vo, cloth extra, gilt, 75. 6id. Bunyan's Pilgrim's Progress.

Edited by Rev. T. ScoTr. With I7 beautiful Steel Plates by STOTHARD, engraved by GOODALL ; and numerous Woodcuts.

\section{Burton's Anatomy of Melancholy:}

A New Edition, complete, corrected and enriched by Translations of the Classical Extracts.

Crown 8vo, cloth extra, gilt, with Illustrations, 7 s. $6 d$.

Byron's Letters and Journals.

With Notices of his Life. By Thomas Moore. A Reprint of the Original Edition, newly revised, with Twelve full-page Plates.

Campbell's (Sir G.) White and Black:

Travels in the United States. By Sir GeORgB CAMPBELL, M.P. 
Demy $8 \mathrm{vo}$, cloth extra, with Illustrations, $75.6 d$.

Caravan Route (The) between Egypt and Syria. By His Imperial and Royal Highness the ARCHDUKE LuDwig SALVATOR of AUSTRIA. With 23 full-page Illustrations by the Author.

\section{Post 8 vo, cloth extra, is, $6 d$.}

\section{Carlyle (Thomas) On the Choice of Books.}

With a Life of the Author by R. H. SHEPHERd. Entirely New and Revised Edition.

\section{Crown 8vo, cloth extra, 75. 6 d. \\ Century (A) of Dishonour: \\ A Sketch of the United States Government's Dealings with some of the Indian Tribes.}

\section{Crown 8vo, cloth extra, with Illustrations, $75.6 d$. \\ Chap-Books.-A History of the Chap-Books} of the Eighteenth Century. By JOHN AsHTON. With nearly 400 Illustrations, engraved in facsimile of the originals. [ $1 n$ the press. *** A few Large-Paper copies will be carefully printed on hand-made. paper, for which early application should be made.

\section{Large 4 to, half-bound, profusely lllustrated, $28 \mathrm{~s}$.}

\section{Chatto and Jackson.-A Treatise on Wood}

Engraving : Historical and Practical. By William ANDREw ChatTo and JOHN JACKSON. With an Additional Chapter by HENRY G. BOHN; and 450 fine Illustrations. A reprint of the last Revised Edition.

Small 4to, cloth gilt, with Coloured Illustrations, ros. $6 d_{\text {. }}$

Chaucer for Children:

A Golden Key. By Mrs. H. R. HAwers. With Eight Coloured Pictures and numerous Woodcuts by the Author.

\section{Chaucer for Schools.} Demy 8vo, cloth limp, 2s. $6 d$.

By Mrs. HAwEIS, Author of "Chaucer for Children."

Crown 8vo, cloth limp, with Map and Illustrations, 2s. $6 d$. Cleopatra's Needle:

Its Acquisition and Removal to England. By Sir J. E. ALEXANDER.

Crown 8vo, cloth extra, gilt, 7s. 6d.

\section{Colman's Fumorous Works:}

" Broad Grins," "My Nightgown and Slippers," and other Humorous Works, Prose and Poetical, of George Colman. With Life by G. B. Buckstone, and Frontispiece by HOGARTH. 


\section{Convalescent Cookery:}

\section{Post 8vo, cloth limp, 2s. $6 d$.}

A Family Handbook. By CATHERINE RYAN.

Conway (Moncure D.), Works by:

Demonology and Devil-Lore. By Moncure D. Conway, M.A. Two Vols., royal 8vo, with 65 Illustrations, $28 \mathrm{~s}$.

A Necklace of Stories. By Moncure D. Conway, M.A. Illustrated by W. J. Hinnnessy. Square $8 v 0$, cloth extra, $6 s$.

The Wandering Jew. By Moncure D. Conway, M.A. Crown $8 \mathrm{vo}$, cloth extra, 6 s.

Thomas Carlyle. By Moncure D. CoNwar, M.A. With Illustrations. Crown $8 v o$, cloth extra, $6 s$.

Two Vols., crown 8vo, cloth extra, 2 Is.

Cook (Dutton).-Hours with the Players. By DutToN Cook.

Post 8vo, cloth limp, 2s. 6 .

Copyright.-A Handbook of Finglish and Foreign Copyright in Literary and Dramatic Works. Being a concise Digest of the Laws regulating Copyright in the Chief Countries of the World, together with the Chief Copyright Conventions existing between Great Britain and Foreign Countries. By SIDNEY JERROLD, of the Middle Temple, Esq., Barrister-at-Law.

\section{Cornwall.-Popular Romances of the West \\ Crown 8vo, cloth extra, 7s. $6 i$.}

of England ; or, The Drolls, Traditions, and Superstitions of Old Cornwall. Collected and Edited by ROBERT HUNT, F.R.S. New and Revised Edition, with Additions, and Two Steel-plate Illustrations by GEORGE CRUIKSHANK. $\lambda$

Crown $8 \mathrm{vo}$, cloth extra, gilt, with $I_{3}$ Portraits, $7 s .6 d$.

Creasy's Memoirs of Eminent Ftonians;

with Notices of the Early History of Eton College. By Sir EDWARD CREASY, Author of "The Fifteen Decisive Battles of the World."

Crown 8vo, cloth extra, with Etched Frontispiece, 7s. $6 d$.

Credulities, Past and Present.

By William Jones, F.S.A., Author of "Finger-Ring Lore," \&c.

Crown 8vo, cloth extra, 6 s.

Crimes and Funishments.

Inciuding a New Translation of Beccaria's "Dei Delitti e delle Pene," By JAMES ANSON FARrer. 
Crown 8vo, cloth gilt, Two very thick Volumes, 7s. 6d. each.

\section{Cruikshank's Comic Almanack.}

Complete in TwO SERIES: The FIRST from 1835 to 1843 ; the SECOND from 1844 to 1853 . A Gathering of the BEST Humour of

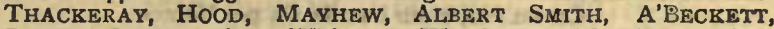
ROBERT BROUGH, \&c. With 2,000 Woodcuts and Steel Engravings by CRUIKSHANK, HiNe, LANDELIS, \&c.

Two Vols., crown 8 vo, cloth extra, with Illustrations, 24 s.

Cruikshank (The Life of George).

In Two Epochs. By BLANChARD JERROLD, Author of "The Life of Napoleon III.," \&c. With numerous Illustrations, and a List of his Works.

[n preparation.

Two Vols., demy 4 to, handsomely bound in half-morocco, gilt, profusely Illustrated with Coloured and Plain Plates and Woodcuts, price 6775 .

\section{Cyclopædia of Costume;}

or, A Dictionary of Dress-Regal, Ecclesiastical, Civil, and Militaryfrom the Earliest Period in England to the reign of George the Third: Including Notices of Contemporaneous Fashions on the Continent, and a General History of the Costumes of the Principal Countries of Europe. By J. R. Planche, Somerset Herald.

The Volumes may also be had separately (each Complete in itself) at $£_{3}$ I3s.6 $_{6}$. each : V01. I. THE DIOTIONARY.

Vol. II. A GENERAI HISTORY OF COSTUME IN EUROPB.

Also in 25 Parts, at 5 s. each. Cases for binding, 5s, each.

"A comprehensive and highly valuable book of reference. . . We have varely failed to find in this book an account of an article of dress, wilile in mos: of the entries curious and instructive details are given. . . Mr. Planche's enormous labour of love, the production of a text which, whether in its dictionary form or in that of the 'General History,' is within its intended scope immeasurably the best and richest work on Costume in English. . . This book is not only one of the most readable works of the kind, lut intrinsically attractive and amusing."-АTHENAUM.

"A most readable and interesting work-and it can scarcely be consulted in vain, whether the reader is in search for information as to military, court, ecclesiastical, legal, or professional costame. . . All the chromo-lithographs, and most of the woodcut illustrations - the latter amounting to several thousands -are wery elaborately executed; and the work forms a livre de luxe which renders it equally suited to the library and the ladies' drawing-room." -TIMrS.

Demy 8vo, cloth extra, I2s, $6 d$.

Doran's Memories of our Great Towns.

With Anecdotic Gleanings concerning their Worthies and thelr Oddities. By Dr. JOHN DORAN, F.S.A.

Two Vols., crown 8vo, cloth extra, 21s. .

Drury Lane, Old:

Fifty Years' Recollections of Author, Actor, and Manager. By EDWARD STIRLING. 
Demy 8vo, cloth, r6s.

\section{Dutt's India, Past and Present;} with Minor Essays on Cognate Subjects. By SHOSHeE Chundea DuTT, Rái Bábádoor.

Crown 8vo, clotb boards, 6s. per Volume.

\section{Early English Poets.}

Edited, with Introductions and Annotations, by Rev. A. B. Grosart.

I. Fletcher's (Giles, B.D.) Com.

plete Poems: Christ's Victorie in

Heaven, Christ's Victorie on Earth,

Christ's Triumph over Death, and

Minor Poems. With Memorial-Introduction and Notes. One Vol.

2. Davies' (Sir John) Complete

Poetical Works, including Psalms I. to $L$. in Verse, and other hitherto Unpublished MSS., for the first time Collected and Edited. MemorialIntroduction and Notes. Two Vols.

3. Herriok's (Robert) Hespert. des, Noble Numbers, and Complete. Collected Poems. With Memorial. Introduction and Notes, Steel Por: trait, Index of First Lines, and Glossarial Index, \&c. Three Vols.

4. Sidney's (Sir Philip) Com. plete Poetical Works, Including all those in "Arcadia." With Portrait, Memorial-Introduction, Essay on the Poetry of Sidney, and Notes. Three Vols.

Imperial 8vo, with 147 fine Engravings, half-morocco, $3^{6 s}$.

Early Teutonic, Italian, and French Masters (The). Translated and Edited from the Dohme Series, by A. H. KEANE, M.A.I. With numerous Illustrations.

"Cannot fail to be of the utmost use to students of art history."-TrMrS.

Crown $8 v e$, cloth extra, gilt, with Illustrations, $6 s$.

Emanuel On Diamonds and Precious

Stones ; their History, Value, and Properties; with Simple Tests for ascertaining their Reality. By HARRY EMANUEL, F.R.G.S, Witb numerous Illustrations, Tinted and Plain.

\section{Crown 8vo, cloth extra, with Illustrations, 7s. $6 d$.}

Fnglishman's House, The:

A Practical Guide to all interested in Selecting or Building a House, with fuil Estimates of Cost, Quantities, \&c. By C. J. RICHARDSON. Third Edition. With nearly 600 Illustrations.

Crown 8vo, cloth extra, with nearly 300 lllustrations, 7 s. $6 d$.

Evolution, Chapters on;

A Popular History of the Darwinian and Allied Theories of Development. By ANDREW WILSON, Ph.D., F.R.S. Edin. \&c. [In preparation.

Evolutionist (The) At Large.

Crown 8vo, cloth extra, 6s.

By Grant Allen.

By the same Author. Crown 8vo, cloth extra, 6s.

Vignettes from Nature.

By Grant ALlen.

[In preparation. 
Folio, cloth extra, 6 I Irs. $6 d$.

\section{Examples of Contemporary Art.}

Etchings from Representative Works by living English and Forelgn

Artists. Edited, with Critical Notes, by J. Comyns CARR.

"It woxild not be easy to meet with a more sumptuous, and at the same time a more tasteful and instructive drawing-room book." -NONCONFORMIST.

\section{Fairholt's Tobacco:}

Crown 8vo, cloth extra, with Illustrations, $6 s$.

Its History and Associations; with an Account of the Plant and its Manufacture, and its Modes of Use in all Ages and Countries. By F. W. FAIRHOLT, F.S.A. With Coloured Frontispiece and upwards of roo Illustrations by the Author.

\section{Familiar Allusions:}

\section{Crown 8vo, cloth extra, $7 s .6 d$.}

A Handbook of Miscellaneous Information; including the Names of Celebrated Statues, Paintings, Palaces, Country Seats, Ruins, Churches, Ships, Streets, Clubs, Natural Curiosities, ahd the like. By William A. WheEler, Author of "Noted Names of Fiction;" and CharLes G. WhEELER.

[In the press.

Crown 8vo, cloth extra, with Illustrations, $4 s .6 d$.

Faraday's Chemical History of a Candle.

Lectures delivered to a Juvenile Audience. A New Edition. Edited

by W. CROOKES, F.C.S. With numerous Illustrations.

Crown 8vo, cloth extra, with Illustrations, 4 s. $6 d$.

Faraday's Various Forces of Nature.

New Edition. Edited byW. CrOOKES, F.C.S. Numerous Illustrations.

Finger-Ring Lore:

Crown 8vo, cloth extra, with Illustrations, 7s. $6 d$.

Historical, Legendary, and Anecdotal. By WM. JONEs, F.S.A. With

Hundreds of Illustrations of Curious Rings of all Ages and Countries.

"One of those gossiping books which are as full of amusement as of instruction."-ATHEN

\section{Gardening Books:}

A Year's Work in Garden and Greenhouse: Practical Advice to Amateur Gardeners as to the Management of the Flower, Fruit, and Frame Garden. By George Glenny. Post 8vo, cloth limp, 2s. 6d.

Our Kitchen Garden: The Plants we Grow, and How we Cook Them. By Tom Jerrold, Author of "The Garden that Paid the Rent," \&c. Post 8vo, cloth limp, 2s. 6d.

Fousehold Horticulture : A Gossip about Flowers. Ву Том and JANe Jerrold. Illustrated. Post 8vo, cloth limp, 2s. $6 d$.

My Garden Wild, and What I Grew there. By Francis GEORGE HEATIT. Crown 8vo, cloth extra, $5 s$. 


\section{One Shilling Monthly. \\ Gentleman's Magazine (The), for 1882.}

The JANUARy Number of this Periodical will contain the First Chapters of a New Serial Story, entitled "Dust," by JULIAN HAWTHORNE, Author of "Garth," \&c. "Science Notes," by W. MAtTiEU WILliaMS, F.R.A.S., will also be continued monthly.

* Now ready, the Volume for JANUARY to JUNE, I88x, cloth extra, price 8., 6a.; and Cases for binding, price 2s. each.

\section{Demy 8vo, illuminated cover, $\mathbf{I s}$.}

Gentleman's Annual, The.

Containing Two Complete Nove!s.

[Nog. 15.

THE RUSKIN GRIMM.-Square 8vo, cloth extra, 6s. 6\%.; gilt edges, 7s. $6 d$.

\section{German Popular Stories.}

Collected by the Brothers GRIMM, and Translated by EDGAR TAYLOR. Edited with an Introduction by JOHN RUSKIN. With 22 Illustrations after the inimitable designs of GEORGE CRUIKSHANK. Both Series Complete.

"The illustrations of this volume . . are of quite sterling and admirable nrt, of a class precisely parallel in elevation to the character of the tales which they illustrate; and the original etchings, as I have before said in the Appendix to my 'Elements of Drawing', were unrivalled in masterfulness of touch since $R \mathrm{em}$ brandt (in some qualities of delineation, unrivalled even by him). . . . To make zomezwhat enlarged copies of them, looking at them through a magnifying glass, and never putting two lines where Cruikshank has put only one, would be an exercise in decision and severe drawing which would leave afterwards little to be learnt in schools."-Extract from Introauction by JOHN RUSkiN.

Post 8vo, cloth limp, 2s. 6d.

\section{Glenny's A Year's Work in Garden and}

Greenhouse : Practical Advice to Amateur Gardeners as to the Manage. ment of the Flower, Fruit, and Frame Garden. By George GlenNy.

"A great deal of valuable information, conveyed in very simple language. The emateur need not wish for a better guide." - LERDS MERCURY.

Crown 8 vo, cloth gilt and gilt edges, 7 s. $6 d$.

\section{Golden Treasury of Thought, The:}

An ENCYCLOPEDIA OF QUOTATIONS from Writers of all Times and Countries. Selected and Edited by THEODORE TAYLOR

New and Cheaper Edition, demy 8vo, cloth extra, with Illustrations, 75.6d.

Greeks and Romans, The Life of the,

Described from Antique Monuments. By ERNST GuHL and W. KONER. Translated from the Third German Edition, and Edited by Dr. F. HuEFFER. With 545 Illustrations. 
Square r6mo (Tauchnitz size), cloth extra, 25. per volume.

Golden Library, The:

Ballad History of England. By W. C. BENNETT.

Bayard Taylor's Diversions of the Echo Club.

Byron's Don Juan.

Fmerson's Letters and Social Aims.

Godwin's (William) Lives of the Necromancers.

Bolmes's Autocrat of the Breakfast Table. With an Introduc tion by G. A. SAla.

Holmes's Professor at the Breakfast Table.

Food's Whims and Oddities. Complete. With all the original I]lustrations

Irving $\mathrm{g}$ (Washington) Tales of a Traveller.

Irving's (Washington) Trles of the All ambra.

Jesse's (Edward) Scenes and Occupations of Country Life.

Lamb's Essays of Elia. Both Serles Complete in One Vol.

Leigh Hunt's Essays: A Tale for a Chimney Corner, and other Pieces. With Portrait, and Introducton by EDMUNd Oltier.
Mallory's (Sir Thomas) Mort d'Arthur: The Stories of King Arthur and of the Knights of the Round Table. Edited by B.Montgomrris RANKING.

Pascal's Provincial Letters. A New Translation, with Historical In. troduction and Notes, by T. M'Crix, D.D.'

Pope's Poetical Works. Com. plete.

Rochefouoauld's Maxims and Moral Reflections. With Notes, and an Introductory Essay by SAINT EBruve.

St. Plerre's Paul and Virginis, and The Indian Cottage. EdIted, with Life, by the Rev. E. CLARKR.

Stelley's Early Poems, and Queen Mab, with Essay by Loxigls HUNT.

Shelley's Later Poems : Laon and Cythna, \&c.

Shelley's Posthumous Poems, the Shelley Papers, \&c.

Shelley's Prose Works, includ. Ing A Refutation of Deism, Zastrozzi, St. Irvyne, \&c.

White's Natural History of Sel. borne. Edited, with Additions, by Thomas BRown, F.L.S.

\section{Guyot's Earth and Man;}

Crown 8vo, cloth extra, gilt, with Illustrations, 4s. $6 d$.

or, Physical Geography in its Relation to the History of Mankind.

With Additions by Professors AgAssiz, PierCE, and GRAY ; I2 Mapg and Engravings on Steel, some Coloured, and copious Index.

\section{Hake (Dr. Thomas Gordon), Poems by:}

Maiden Ecstasy. Small 4to, cloth extra, 8s.

Now Symbols. Crown 8vo, cloth extra, $6 s$.

Iegends of the Morrow. Crown 8vo, cloth extra, $6 s$.

$$
\text { Medium 8vo, cloth extra, gilt, with Illustrations, 7s. 6d. }
$$

Hall's(Mrs. S. C.) Sketches of Irish Character.

With numerous Illustrations on Steel and Wood by MAcLISE, GiL. BERT, HARVEY, and G. CRUIKSHANK.

"The Irish Sketches of this Zady resemble Miss Mitford's beautiful English sketches in 'Our Village,' but they are far more vigorous anci ficturesque atec brignt." - Blackwood's MAGAzINe. 


\section{सaweis (Mrs.), Works by:}

The Art of Dress. By Mrs. H. R. HAwErs. Illustrated by the Author. Small 8vo, illustrated cover, is.; cloth limp, is. $6 d$.

"A vell-considered attempt to apply canons of pood taste to the costumss of ladies of our time. . . . Mrs. Hazveis writes frankly and to the point, she docs not mince matters, but boldly remonstrates with her ofus ses. on the follies they indulge in. : . . We may recommend the book to the ladies whom it concerns."-ATHEN mUM.

The Art of Beauty. By Mrs. H. R. HAwers. Square 8vo, cloth extra, gilt, gilt edges, with Coloured Frontispicce and nearly 100 Illustrations, Ios. $6 d$.

The Art of Decoration. By Mrs. H. R. HAweis. Square 8vo, handsomely bound and profusely Illustrated, ros. $6 d$.

* * See also Chaucer, $p .5$ of this Catalogue.

Heath (F. G.) - My Grorden Wild,

And What I Grew there. By Francis George Heatr, Author of

"The Fern World," \&c.

SPECIMENS OF MODERN POETS.-Crown 8vo, cloth extra, 6s. Heptalogia (The); or, The Seven against Sense.

A Cap with Seven Bells.

"The merits of the book cannot be fairly estimated by means of a few extracts ; it should be read at length to be appreciated properly, and, in our opinion, its merits entitle it to be very widely read indeed."-ST. JAMES'S GAZRTTE.

Cr. 8vo, bound in parchment, 8s.; Large-Paper copies (only 50 printed), 155 . Herbert.-The Poems of Lord Herbert of Cherbury. Edited; with an Introduction, by J. ChuRTON COLLINS.

Complete in Four Vols., demy 8vo, cloth extra, r2s, each.

History of Our Own Times, from the Accession of Queen Victoria to the General Election of I830. By JUST1N MCCARTHY, M.P.

"Criticism is disarmed before a composition which provokes little but approval. This is a really good book on a really interesting swiject, and words piled on words could say no more for it." - SATURDAY REVIHW.

New Work by the Aulhor of "A HISTORY of OUR OWN TIMES."

Four Vols. demy $8 \mathrm{vo}$, cloth extra, I2s. each.

\section{History of the Four Georges.}

By JUSTIN MCCarthy, M.P. [In preparation.

Crown 8 vo, cloth limp, with Illustrations, 2s, $6 d$.

Holmes's The Science of Voice Production

and Voice Preservation: A Popular Manual for the Use of Speakers and Singers. By GoRDON HOLMES, L.R.C.P. $\mathrm{E}$. 


\section{Crown 8vo, cloth extra, gilt, $75.6 d$.}

\section{Hood's (Thomas) Choice Works,}

In Prose and Verse. Including the CREAM OF THE CoMic ANNUALs. With Life of the Author, Portrait, and Two Hundred Illustrations.

\section{Square crown $8 \mathrm{vo}$, cloth extra, gilt edges, 6 s.}

Hood's (Tom) From Nowhere to the North

Pole : A Noah's Arkæological Narrative. With 25 Illustrations by

W. BRUNTON and E. C. BARNES.

"The amusing letterpress is profusely interspersed with the jingling rhymes which children love and learn so easily. Messrs. Brunton and Barnes do full justice to the writer's meaning, and a pleasanter result of the harmomious cc. operation of author and artist could not be desired." -TIMrs.

Iook's (Theodore) Choice Humorous Works, including his Ludicrous Adventures, Bons-mots, Puns, and Hoaxes: With a new Life of the Author, Portraits, Facsimiles, and Illustrations.

\section{Horne's Orion:}

$$
\text { Crown } 8 \mathrm{vo} \text {, cloth extra, } 7 s \text {. }
$$

An Epic Poem in Three Books. By Richard Hengist Horne. With a brief Commentary by the Author. With Photographic Portrait from a Medallion by Summers. Tenth Edition. Crown 8vo, cloth extra, 75. 6d.
Howell's Conflicts of Capital and Labour
Historically and Economically considered. Being a History and

Review of the Trade Unions of Great Britain, showing their Origin, Progress, Constitution, and Objects, in their Political, Social, Economical, and Industrial Aspects. By GEORGE HOWELL.

"This book is an attempt, and on the whole a successfui attempt, to place the zvork of trade wnions in the past, and their objects in the future, fairly tefore the public from the working man's point of view." - PALL MALL GAZBTTB.

\section{Hueffer's The Troubadours: \\ Demy 8vo, cloth extra, i2s. $6 d$.}

A History of Provencal Life and Literature in the Middle Ages. By FRANCIS HUEFEER.

\section{Janvier.-Practical Keramics for Students.}

By Catherine A. Janvier.

"Will be found a useful handbook by those who wish to try the manufacture or decoration of pottery, and may be studied by all who desire to know something of the art." - MORNING POST.

A NEw EDITION, Revised and partly Re-written, with several New

Chapters and Illustrations, crown 8vo, cloth extra, 7s. $6 d$.

\section{Jennings' The Rosicrucians:}

Their Rites and Mysteries. With Chapters on the Ancient Fire and Serpent Worshippers. By Hargrave Jennings. With Five fullpage Plates and upwards of 300 Illustrations. 


\section{Jerrold (Tom), Works by:}

Household Horticulture: A Gossip about Flowers. By TOM and JANe Jerrold. Illustrated. Post 8vo, cloth limp, 2s.6d.

Our Kitchen Garden : The Plants we Grow, and How we Cook Them. By TOM JRRrol, Author of "The Garden that Paid the Rent," \&c. Post 8vo, cloth limp, 2s. $6 d$.

"The combination of hints on cookery with gardening has been very cleverly carried out, and the result is an interesting and highly instructive little work. Mr. Ferrold is correct in saying that English people do not make half the use of vegetables they might; and by shozving horv easily they can be grown, and so obtained fresh, he is doing a great deal to make them more popular." -DAILY CHRONICLE.

Two Vols. 8vo, with 52 Illustrations and Maps, cloth extra, gilt, 14s.

\section{Josephus, The Complete Works of.}

Translated by Whiston. Containing both "The Antiquities of the Jews" and "The Wars of the Jews."

Small 8vo, cloth, full gilt, gilt edges, with Illustrations, $6 \mathrm{~s}$.

Kavanaghs' Pearl Fountain,

And other Fairy Stories. By BRIDGET and Julla KAVANAGH. With Thirty Illustrations by J. MOYR SMITH.

"Genuine new fairy stories of the old type, some of them as delightful as the best of Grimm's 'German Popular Stories." . For the most part the storiks are down right, thorough-going fairy stories of the most admirable kind.

- . Mr. Moyr Smith's illustrations, too, are admirable."-SPzctator.

Square $8 v o$, cloth extra, with Illustrations, $6 s$.

Knight (The) and the Dwarf.

By Charles Mills. With numerous Illustrations by Thomas LINDSAY.

Crown 8vo, illustrated boards, with numerous Plates, 2s. $6 d^{\circ}$

Lace (Old Point), and How to Copy and Imitate it. By DAISY WATERhouse HAWk1NS. With I7 Illustrations by the Author.

Crown 8vo, cloth extra, gilt, with Portraits, $7 s .6 d$.

\section{Lamb's Complete Works,}

In Prose and Verse, reprinted from the Original Editions, with many Pieces hitherto unpublished. Edited, with Notes and Introduction. by R. H. Shepherd. With Two Portraits and Facsinile of a Page of the "Essay on Roast Pig."

"A complete edition of Lamb's writings, in prose and verse, has long been ranted, and is now supplied. The editor appears to have taken great pains to oring together Lamb's scattered contributions, and his collection contains a number of pieces which are now reproduced for the first time since their origina? appearance in various old feriodicels." - EATVRAY REVIB. 
Crown 8vo, cloth extra, with numerous Illustrations, ros. $6 d$.

\section{Lamb (Mary and Charles):}

Their Poems, Letters, and Remains. With Reminiscences and Notes by W. CAREW HAzLITT. With HANCOCK's Portrait of the Essayist, Facsimiles of the Title-pages of the rare First Editions of Lamb's and Coleridge's Works, and numerous Illustrations.

"Very many passages will delight those fond of literary trifies; hardly any portion will fail in interest for lovers of Charles Lamb and his sister."-STANDARD.

\section{Small 8vo, cloth extra, 5 s. \\ Lamb's Poetry for Children, and Prince}

Dorus. Carefully Reprinted from unique copies.

"The quaint and delightful little book, over the recovery of which all the hearts of his lovers are yet warm with rejoicing." -A. C. SwINBURNE.

\section{Lares and Penates;}

Crown 8 vo, cloth extra, $6 s$.

Or, The Background of Life. By FLORENCE CADDY.

"The zuhole book is well warth reading, for it is full of practical suggestions. - We hope nobody will be deterred from taking up a book which teaches a good deal about sweetening poor lizes as well as giving grace to zecalthy ones." GRAPHIC.

Crown 8 vo, cloth, full gilt, $6 \mathrm{~s}$.

\section{Leigh's A Town Garland.}

By HENRY S. Leigh, Author of "Carols of Cockayne."

"If Mr. Leigh's verse survive to a future generation-and there is no reasun why that honour should not be accorded productions so delicate, so finished, ard so full of humour-their author will probably be remembered as the Poet of the Strard." - ATHRNAUM.

SECoNd EdTION.-Crown 8vo, cloth extra, with Illustrations, 6s. Leisure-Time Studies, chiefly Biological.

By ANDREw WILSON, F.R.S.E., Lecturer on Zoology and Compara.

tive Anatomy in the Edinburgh Medical School.

"It is well when we can take up the work of a really qualified investigator. who in the intervals of his more serious professional labours sets kimself to impart Enozuledge in such a simple and elementary form as may attract and instruct, with no danger of misleading the tyro in natural science. Such a work is this little volume, made up of essays and addresses written and delivered by Dr. Andrew Wilson, lecturer and examiner in science at Edinburgh and Glasgoze, at Zeisure intervals in a busy professional life. . . . Dr. Wilson's pages teem with matter stimulating to a healthy love of science and a reverence for the truths of nature." - SATURDAY REVIEW.

\section{Life in London;}

Crown 8vo, cloth extra, with Illustrations, 7s. $6 d$,

or, The History of Jerry Hawthorn and Corinthian Tom. With the whole of CRUIKSHANK's Illustrations, in Colours, after the Originals, 


\section{Lights on the Way:}

\section{Crown 8 vo, cloth extra, 6 s.}

Some Tales within a Tale. By the late J. H. Alexander, B.A. Edited, with an Explanatory Note, by H. A. PAGE, Author of "Thoreau I A Study."

\section{Crown 8vo, cloth extra, with Illustrations, 7s. $6 d$. \\ Longfellow's Complete Prose Works.}

Including "Outre Mer," "Hyperion," "Kavanagh," "The Poets and Poetry of Europe," and "Driftwood." With Portrait and Illustrations by VALENTINE BROMLEY.

Crown 8vo, cloth extra, gilt, with Illustrations, 75. $6 d$.

Longfellow's Poetical Works.

Carefully Reprinted from the Original Editions. With numerous fine Illustrations on Steel and Wood.

Crown 8vo, cloth extra, 5 s.

\section{Lunatic Asylum, My Experiences in a.}

By a SANE PATIENT.

"The story is clever and interesting, sad beyond measure though the swbject be. There is ne personul bitterness, and no violence or anger. Whatever may have been the evidence for our author's madness when he was consigned to an asylum, nothing car be clearer than his sanity when he wrote this book; it is bright, calm, and to the point."-SPECTATOR.

Demy 8vo, with Fourteen full-page Plates, cloth boards, x8s.

\section{Lusiad (The) of Camoens.}

Translated into English Spenserian verse by ROBERT FFRENCH DUFF, Knight Commander of the Portuguese Royal Order of Christ.

\section{Mallock's (W. H.) Works :}

Is Life Worth Iiving? By William HURRELL MALLOCK.

New Edition, crown 8vo, cloth extra, 6s,

"Thie deeply interesting volume. . . . . It is the most powerful vin dication of religion, both natural and revealed, that has appeared since Bishot Butler wrote, and is much more usefiul than either the Analogy or the Ser. mons of that great divine, as a refutation of the peculiar form assumed iy the infidelity of the present day. . . . Deeply philosophical as the boon is, there is not a heavy page in it. 'The writer is 'possessed,' so to speak, with his great subject, has sounded its depths, surveyed it in all its extent, and brought to bear on it all the resources of a vivid, rich, and impassioned style, as well as an adeguate acguaintance with the science, the philososhy, and the literature of the day."-IRISH DAILY Nrws.

The New Republio; or, Culture, Faith, and Philosophy in an English Country House. By W. H. Malzock. Post 8vo, cloth limp, 2s. 6 d. The New Paul and Virginia; or, Positivism on an Island. By W. H. Mallock. Post $8 \mathrm{vo}$, cloth limp, 2s. 6 d.

Poems. By W. H. Mallock. Small 4 to, bound in parcliment, 8 s. $\Delta$ Romance of the Nineteenth Centurs. By W. H. MaLlQCK. Second Edition, with a Preface. Two Vols., crown 8vo, 21s. 


\section{Macquoid (Mrs.), Works by:}

In the Ardennes. By Katharine S. Macedoid. With 50 fine Illustrations by THOMAS R. MACQUOID. Uniform with " Pictures and Legends." Square 8vo, cloth extra, ros. 6d.

" $T$ his is another of Mrs. Macquoid's pleasant books of travel, full of useful information, of picturesque descriptions of scenery, and of quaint traditions respecting the various monuments and ruins which she encounters in her tour. . . . To such of our readers as are already thinking about the year's holiday, we strongly recommend the perusal of Mrs. Macquoid's experiences. The book is well illustrated by Mr. Thomas R. Macquoid."-GrapHic.

Pictures and Legends from Normandy and Brittany. By Katharine S. MacQuoid. With numerous Illustrations by Thomas R. MacQuold. Square 8vo, cloth gilt, ros. $6 d$.

Through Normandy. By KaTHARINe S. MAcQuord. With go Illustrations by T. R. MACQuon. Square 8vo, cloth extra, 7s. 6d.

"Ore of the few books which can be read as a piece of literature, whilst at the same time handy in the knapsack."-BRITISH QUARTERLY REYIEW.

Through Brittany. By Katharine S. Macquoid. With numerous Illustrations by T. R. MACQuord. Sq. 8vo, cloth extra, 75. 6d.

"The pleasant companionship whick Mrs. Macquoid offers, while wander. ing from one point of interest to another, seems to throw a renewed charm around each oft-depicted scene."-MORNING POST.

\section{Mark Twain's Works:}

The Choice Works of Mark Twain. Revised and Corrected throughout by the Author. With Life, Pertrait, and numerous Illustra. tions. Crown 8vo, cloth extra, 75. 6d.

The Adventures of Tom Sawyer. By MARK Twain. With roo Illustrations. Small 8vo, cloth extra, 7s.6d. CHEAP EDITION, illustrated boards, $2 s$.

A Pleasure Trip on the Continent of Europe: The Innocents Abroad, and The New Pilgrim's Progress: By Mark Twain. Post 8vo, illustrated boards, $2 s$.

An Idle Exoursion, and other Sketches. By MARK TwaIN, Post 8vo, illustrated boards, 2s.

The Prince and the Pauper. By MARK TwaIn. With nearly 200 Illustrations. Crown 8vo, cloth extra, 75. 6d. Uniform with " A Tramp Abroad."

[In the press.

The Innocents Abroad; or, The New Pilgrim's Progress : Being some Account of the Steamship "Quaker City"s " Pleasure Excursion to Europe and the Holy Land, with descriptions of Countries, Nations, Incidents, and Adventures, as they appeared to the Author. With 234 Illustrations. By MARK TWAIN, Crown 8vo, cloth extra, 7s. 6d. Uniform with "A Tramp Abroad."

A Tramp Abroad. By MARK Twain. With 314 Illustrations. Crown 8vo, cloth extra, $75.6 d$.

"The fun and tenderness of the conceftion, of which no living man but Mark Twain is capable, its grace and fantasy and slyness, the wonderful feeling for animals that is manifest in every line, make of all this episode of Fim Baker and his jays a piece of work that is not only delightful as mere reading, but also of a high degree of merit as literature. . . The book is full of good things, and contains passages and episodes that are equal to the furniest of those that have gone before."-ATHENAUM. 
Crown 8vo, cloth extra, with Illustrations, 2s. $6 d$.

Madre Natura $\nabla$. The Moloch of Fashion.

By LUKE LIMNER. With 32 Illustrations by the Author. FOURTE EDITION, revised and enlarged.

\section{Magna Charta.}

Handsomely printed in facsimile, price 5 .

An exact Facsimile of the Original Document in the British Museum, printed on fine plate paper, nearly 3 feet long by 2 feet wide, with the Arms and Seals emblazoned in Gold and Colours.

Post 8vo, cloth limp, 25. 6d. per volume.

Mayfair Iibrary, The:

The New Republio. By W. H. MaLLock.

The New Paul and Virginia. By W. H. Mallock.

The True History of Joshua Davidson. By E. LYNn Linton.

Old Stories Re-told. By WALTRR THORNBURY.

Thoreau : His Life and Aims. By H. A. PAGr.

By Stream and Sea. By WIL. LIAM SENIOR.

Joux d'Esprit. Edited by HENRY S. LEIGH.

Puniana. By the Hon. Hugh RowLEY.

More Puniana. By the Hon. HugH ROWLEY.

Puok on Pegasus. By $\mathrm{H}$. ChOLMONDELEY-PRNNRL,.

The Speeches of Charles Dickens.

Muses of Mayfair. Edited by H. Cholmandeley-Pznnel.

Gastronomy as a Fine Art. By BRILLAT-SAVARIN.

The Ihilosophy of Hand. writing. By DON FELIX DE SALAMANCA.

Curiosities of Criticism. By HENRY J. JENNings.

Literary Frivolities, Fancies, Follies, Frolics. By W. T. Dosson. Pencil and Palette. By ROBERT KRMPT.

Latter-Day Iyrics. Edited by W. DAVENPORT ADAMS.
Original Playg by W. S. GILbert. First Series. Containing: The Wicked World-Pygmalion and Galatea - Charity - The PrincessThe Palace of Truth-Trial by Jury.

Original Plays by W. S. GIL. Bert. Second Serims. Containing: Broken Hearts - Engaged - Sweethearts - Dan'l Druce - GretchenTom Cobb-The Sorcerer-H.M.S. Pinafore-The Pirates of Penzance.

Carols of Cockayne. By HENRY S. LEIGH.

The Book of Clerical Anec. dotes. By JACOB LARwoOd.

The Agony Column of "The Times," from I800 to 1870 . Edited, with an Introduction, by ALICE CLAY.

The Cupboard Papers. By Fin-Brc.

Pastimes and Players. By ROBERT MACGREgor.

Melancholy Anatomised: A Popular Abridgment of "Burton's Anatomy of Melancholy."

Quips and Quiddities. Selected by W. DAYRNiport AdAMS.

Leaves from a Naturalist's Note-Book. By ANDREW WiLson, F.R.S.E.

The Autocrat of the Break. fast-Table. By OLIVER WENDELL Holmes. Illustrated by J. GORDON Tномson.

Balzac's "Comédie Humaine" and its Author. With Translations by H. H. WALKER.

* *ther Volumes are in preparation. 


\section{Small $8 \mathrm{vo}$, cloth limp, with Illustrations, $2 s .6 d$. Miller's Physiology for the Young;}

Or, The House of Life: Human Physiology, with its Applications to the Preservation of Health. For use in Classes and Popular Reading. With numerous Illustrations. By Mrs. F. FENWICK MILler.

"An admirable introduction to a subject which all who valwe health and enjoy life should have at their fingers' ends."-ECHO.

IMilton (J. L.), Works by:

The Fygiene of the Skin. A Concise Set of Rules for the Management of the Skin; with Directions for Diet, Wines, Soaps, Baths, \&c. By J. L. MıLton, Senior Surgeon to St. John's Hospital. Small $8 \mathrm{vo}$, Is.; cloth extra, Is. $6 d$.

The Bath in Diseases of the Skin. Small 8vo, Is.; cloth extra, 1s. $6 d$.

Square 8 vo, cloth extra, with numerous Illustrations, $7 s, 6 d$. North Italian Folk.

By Mrs. COMYNS CARR, Illustrated by RANDOLPH CALDECOTT.

"A delightfulbook, of a kind which is far too rare. If anyone wants to really, hnow the North Italian folk, we can honestly advise him to omit the journey, and read Mrs. Carr's pages instead. . Description with Mrs. Carr is a real gift. . It is rarely that a book is so happily illustrated."-CONTBMPORARY REVIEw.

\section{NEW NOVELS.}

\section{A NEW NOVEL BY OUIDA.}

The Title of which will shortly be announced. 3 vols., crown 8 vo.

SOMETHING IN THE CITY.

By Grorgr Augustus Sala. 3 vols. crown 8 vo.

GOD AND THE IMAN.

By Rosert Buchanan, Author of "The Shadow of the Sword," \&c. 3 vols.

crown 8vo. With II Illustrations by FRED, EARNARD.

THE COMET OF A SEASON.

By Justin McCarthy, M.P., Author of "Miss Misanthrope." 3 vols., crown 8 vo.

JOSEPH'S COAT.

By David Christie Murray, Author of "A Life's Atonement," \&c. With I2 Illustrations by FRED. BARNARD.

PRINCE SARONI'S WIFE, and other Stories.

By Julian HAwthoRne. 3 vols., crown 8 vo.

A HEART'S PROBLEIM.

By Charles Gibbon, Author of "Robin Gray," \&c. 2 vols, crown 8vo.

TEE BRIDE'S PASS.

By SARAH TytLer, 2 vols., crown 8vo. 
Crown 8vo, cloth extra, with Vignette Portraits, price 6s. per Vol. Old Dramatists, The:

Ben Jonson's Works.

With Notes, Critical and Explanatory, and a Biographical Memoir by WIL: LIAM GIFFORD. Edited by Colonel Cunningham. Three Vols.

\section{Chapman's Works.}

Now First Collected. Complete in Three Vols. Vol. I. contains the Plays complete, including the doubtful ones; Vol. II. the Poems and Minor Translations, with an Introductory Essay by Algernon Charlis Swinburing. Vol. III. the Translations of the Iliad and Odyssey.

Marlowe's Works.

Including his Translations. Idited, with Notes and Introduction, by Col. Cunningham. One Vol.

Massinger's Plays.

From the Text of William Gifrord.

With the addition of the Tragedy of

"Believe as you List." Edited by Col. Cunningham. One Vol.

\section{O'Shaughnessy (Arthur) Works by:}

Songs of a Worker. By Arthur O'Shaughnessy. Fcap. 8 vo, cloth extra, 7s. $6 d$.

Music and Moonlight. By Arthur O'Shaughnessy. Fcap. 8vo, cloth extra, $7 s .6 d$.

Lays of France. By Artiur O'Shaughnessy, Crown 8vo, cloth extra, 1os. $6 d$.

Crown 8vo, red cloth extra, 5s, each.

Ouida's Novels.-Library Edition.

Hold in Bondage. By OuIDA. Pascarel. By OuIDA. Strathmore.

By OUIDA.

Chandos.

BY OUIDA.

Under Two Flags. By OUIDA.

Idalia.

By OUIDA.

Cecil Castlemaine. Bÿ OUIDA.

Tricotrin.

Puck.

Folle Fàrine.

By OUIDA.

By OUIDA,

By OUIDA.

Two Wooden Shoes, By OUIDA.

Signa.

By OUIDA.

In a Winter City. By OUIDA.

Arisdns.

Friendshlp.

By OUIDA.

Moths.

Pipistrello. By OUIDA.

BY OUIDA.

Dog of Flanders. By OuIDA.

A Village Commune. By OUIDA.

* Also a Cheap Edition of all but the last two, post 8vo, illustrated boards, 2s, esch.

\section{Post 8vo, cloth limp, xs. 6d. \\ Parliamentary Procedure, A Popular Hand-} book of. By HENRY W. LuCY.

\footnotetext{
Large 4to, cloth extra, gilt, beautifully Illustrated, 31s. $6 d$. Pastoral Days ;

Or, Memories of a New England Year. By W. Hamilton Grbson.

With 76 Illustrations in the highest style of Wood Engraving.

"The volume contains a prose poem, with illustrations in the shape of wood eneravings more beautiful than it can well enter into the hearts of most men to concitue." -SCOTSMAN.
} 
LIBRARY EDITIONS, mostly Illustrated, crown 8 vo, cloth extra, $3^{3}, 6 d$. each. Piccadilly Novels, The.

39aputar

Maid, Wife, or Widow P By Mrs. Alexander.

Ready-Money Mortiboy. By W. BESANT and JAMES RICE.

My Little Girl. By W. Besant and JAMES RICE.

The Case of Mr. Lucraft. By W. BESANT and JAMES Rice.

This Son of Vulcan. By W. Besant and James Rice.

With Harp and Crown. By W. BESANT and JAMES Rice.

The Golden Butterfly. By W. BeSANT and JAMES RICE.

By Celia's Arbour. Besant and James Rich.

The Monks of Thelema. By W. BESANT and JAMES RICE.

'Twas in Trafalgar's Bay. By W. BESANT and JAMES Rice.

The Seamy Side. By Walter BESANT and Jamrs Rick.

Antonina. By WILKIE Collris. Basil. By WrLKIH Collins.

Hide and Seek. W. Collins. The Dead Secret. W. Collins. Queen of Hearts. W. ColliNs. My Miscellanies. W. Collins. The Woman in White. By Wilkir Collins.

The Moonstone. W. Collins. Man and Wife. W. Collins.

Poor Miss Finch. W. Collins. Miss or Mrs. P By W. Collins. The New Magdalen. ByWILkI Collins.

The Frozen Deep. W. Collins.

The Law and the Lady. By WILKIR Collins.

The Two Destinies. By WILKIE Collins.

The Eaunted Hotel. ByWILKIE Collins.

The Fallen Leaves. By WILkiz Collins.

Jezebel's Daughter. W. Collins.

Deceivers siver. Lovett Cameron.
Juliet's Guardian. By Mrs, H. Lovgtt CAMzRon.

Felicia. M. BeTHAM-EDWARDS. Olympia. By R. E. Francillon. The Capel Girls. By EDWARD GARRETT.

Robin Graj. Charles GibBon. F'or Lack of Gold. By CHARLES GibBon.

In Love and War. By CHARLES GibBon.

What will the World Say P By Charles Gibbon.

For the King. Charles GiBBON. In Honour Bound. By CHARLES GibBon.

Queen of the Meadow. By Chakles Gibbon.

In Pastures Green. By CharLes GrbBon.

Under the Greenwood Treo. By Thomas Hardy.

Garth. By JULIAN HAwTHORNE. Ellice Quentin. By JulraN HAWTHORNR.

Thornicroft's Model. By Mrs. A. W. Hunt.

Fated to be Free. By Jean INGRLOW.

Confldence. Henry James, Jun. The Queen of Connaught. By HARRIETT JAY.

The Dark Colleen. By H. JAY. Number Sevonteen. By HENRY KINGSLEY.

Oakshott Castle. H. KINGsLeY. Patricia Kemball. By E. LYNN LinTon.

The Atonement of Leam Dun. das. By E. LynN Linton.

The World Well Lost. By E. LYNN LINTON.

Under which Lord? By E. LYNR LINTON.

With a Silken Thread. By E. LYNN LINTON.

The Waterdale Neighbours. By JUSTIN MCCARTHY. 
Piccadilly Novels-continued.

My Enemy's Daughter. By JUSTIN MCCARTHY.

Linley Roohford. By JustiN McCarthy.

A Frir Saxon. J. McCarthy. Dear Lady Disdain. By JustiN McCARTHy.

Miss Misanthrope. By JusTiN McCarthy.

Donna Quixote. J. MCCARTHY.

Quaker Cousins. By AGNes Macdonell.

Lost Rose." Bg Katharinz S. MacQuoid.

The Evil Eye. By Katharine S. Maceuoid.

Open! Sesame! By Frorence MARRYAT.

Written in Fire. F. MARRYAT. Touch and Go. By JEAN MID. DLEMASS.

A Iife's Atonement. By D. Christih MurRay.

Whiteladies. Mrs. OliphaNT. The Best of Husbands. By JAMES PAYN.

$$
\text { NEW VOLUMES OF" THE }
$$

Put Yourself in his Place. By Charles Reade.

A Confidential Agent. By JaMrs PAYN. With 12 Hllustrations. The Violin-Player. By BERTHA Tномаs.

Queen Cophetua. By R. E. FranCILION.

The Leaden Casket. By Mrs. ALPRED HUNT.

Carlyon's Year. By J. PAYN.

The Ten Years' I'enant, and other Stories. By Walter Besant and JAMES RICE.

A Child of Nature. By Robert Buchanan.

Cressida. By Bertha Thomas. From Exile. By JaMes PAyn.
Fallen Fortunes. JAMEs PAXN. Halves. By JAMES PAYN.

Walter's Word. JAMES PAYN. What He Cost Her. J. PAYN. Less Black than we're Painted. By James Payn.

By Proxy. By James PAyn. Under One Roof. JAMES PAYN. High Spirits. By. JAMES PAYN. Her Mother's Darling. By Mrs. J. H. RIDDELL.

Bound to the Wheel. By JoHN SAUNDRRS.

Guy Waterman. J. SAUNDERS. One Against the World. By JoHN SAUNDERS.

The Iion in the Path. By JoHN SAUNDRES.

The Way We Live Now. By ANTHONY TROLLOPE.

The American Senator. By ANTHONY TROLLOPE.

Diamond Cut Diamond. By T. A. TROLLOPE,

\section{Crown 8vo, cloth extra, $6 s$.}

Planché.-Songs and Poems, from 18 I9 to 1879 . Sebastian Strome. By JULIAN HAIVTHORNE.

The Black Robe. By IVILKIE Collins.

Archie Lovell. By Mrs. Annie EDWARDES.

"My Lovel" By E. LYNN IINTON.

Lost Sir Massingbera. By J AIES PAYN.

The Chaplain of the Fleet. By Walter Besant and James Rice.

Proud Maisie. By Bertha THOMAS.

The Two Dreamers. By JOHN SAUNDERS.

What She Came through. By SARAH TytLer.

By J. R. Planche. Edited, with an Introduction, by his Daughter, Mirs. Mackarness. 
Post 8vo, illustrated boards, 2s. each.

\section{Popular Novels, Cheap Editions of.}

[Wilkir Collins' Novels and BrSANT and Ricr's Novels may also behad in cloth limp at 2s. 6\%. See, tos, the Piccadiluv Novels, for Library Editions.]

Confidences. Hamilton AïDE. Carr of Carrigon. H. AïbE. Maid, Wife, or Widow P By Mrs, AlRXaNdER,

Ready-Money Mortiboy. By WALTER BESANT and JAMES Rick. With Barp and Crown. By WALTBR BESANT and JAMES RICE.

This Son of Vulcan. By W. BESANT and James Rice.

My Iditle Girl. By the same. The Case of Mr. Lucraft. By WALtzR BESANT and JAMES Rice. The Golden Butterfly. By W. BesANT and JAMrS Rice.

By Cella's Arbour. By WALTER BESANT and JAMES RICB.

The Monks of Thelema. By Walter Besant and JAMES Rice.

'Twas in. 'Trafalgar's Bay. By WALtER BESANT and JAMBS RICE.

Seamy Side. BEsANT and RICE. Grantley Grange. By SHelsLEY BEAUCHAMP.

An Helress of Red Dog. By BrET HartB.

The Iuck of Roaring Camp. By BRET HARTE.

Gabriel Conroy. Bret Harte. Surly Tim. By F. E. BuRNETT, Deceivers Ever. By Mrs. L. CAMBRON.

Juliet's Guardian. By Mrs. LovetT Cameron.

The Cure of Souls. By MACLAREN COBBAN.

The Bar Sinister. By C. Allston Collins.

Antonina. By WirkinCorLINS. Basil. By Wilkie Collins.

Elde and Seek. W. Collins. The Dead Secret. W. Courins. Queen of Hearts. W. ColliNs. My Miscellanies. W. Coluins. Woman in White. W. CoLLINS. The Moonstone. W. CoLLINS.
Man: and Wifo. W. Colliss. Poor Miss Finoh, W. Collins. Miss ox Mrs: $P$ W. Collins. Now Magdalen. WV. Collins. The Frozen Deep. W. Collins. Law and the Lady. W. ColliNs. Two Destinies. W. Colins. Haunted Hotel. W. ColliNs. Fallen Leaves. By W.Collins. Leo. By Dutton Cook.

A Point of Honour. By Mrs. ANNIE EDWARDES.

ArchieLovell. MrsA.EDWARDES Folleia. M. BETHAM-EDWARDS. Roxy. By EDWARD EGgLESTON, Polly. By Percy Fitzgerald. Bella Donna. P. FitzGerald. Never Forgotten. FITZGERALD. The Second Mrs. Tillotson. By Percy Fitzgerald.

Seventy-FiveBrookeStreet. By PERCY FitzGerald.

Filthy uuere. By ALBANY DR FONBLANQUR:

Olympia. By R. E. FrancilloN. The Capel Girls. By EDward GarretT.

Robin Gray. By Chas. Grbbos. For Lack of Gold. C. GibBon. What will the World Say P By Charlgs Gibbon.

In Honour Bound. C. GIBBON. The Dead Heart. By C. GiBBON. In Love and War. C. GibsoN. Fror the King. By C. GibBon. Queen of the Meadow. By Crarles Gibbon.

Diok Temple. By Janes GrRENWOOD.

Every-day Papers. By ANDREW Hallidav.

Paul Wynter's Sacrifice. By Lady Durfus HARDY.

Under the Greenwood Irce. By THOMAS HARDY. 
Popular Novels-continued. Garth. By Julian Hawthorne. Golden Heart. By ToM Hood. TheHunchback of Notre Dame. By Victor Hugo.

Thornicroft's Model. By Mrs. AlFREd HUNT.

Fated to be Free. By Jran INGELOW.

Confldence. By Henry James, Jun.

The Queen of Connaught. By HARRIETT JAY.

The Dark Colleen. By H. JAy.

Number Seventeen. By HEN Ry KINGSLEY.

Oakshott Castle. H.KINGSLEY. Patricia Kemball. ByE. LyNN LinToN.

Leam Dundas. E.LynNLINTON. The World Well Lost. By E. LYNN LiNToN.

Under which Lord $P$ By E. LYNN LINTON.

The Waterdale Neighbours. By Justin McCarthy.

Dear LadyDisdain. By the same.

My Enemy's Daughter. By JUSTIN MCCARThy.

A Fair Sazon. J. McCarthy. Iinley Roohford. McCARTHY. Miss Misanthrope. McCARTHY. Donna Quizote. J.MCCARTHY. The Evil Eye. By KaTHarin S. MACQuord.

Lost Rose. K. S. MACQUOID. Open! Sesamel By FlorancE MARRYAT.

Harvest of Wild Oats. By FLORENCE MARRYAT.

A Little Stepron. F. MARRYAT. Fighting the Air. F. MARRYAT. Touch and Go. By JEAN Middlemass.

Mr. Dorillion. J. Middlemass. Whiteladies. ByMrs.OlipHanT. Held in Bondage. By OuIDA. Strathmore. By OuIDA. Chandos. By Ouida.

Under Two F'lags. By OuIDA. Idalia. By Ourda.

Oecil Castlemaine. By OUIDA. Trieotrin. By OuIDA. Puck. By OUIDA. Folle Farine. By OuIDA. A Dog of Flanders. By Ovida. Pascarel. By OuIDA.

Two Little Wooden Shoes. By Signa. By OUIDA. [OUIDA. In a Winter City. By OUIDA. Ariadne. By OuIDA. Friendship. By OuIDA. Moths. By OuIDA.

Lost Sir Massingberd. J. PAYN. A Perfect Treasure. J. PAyN. Bentinck's Tutor. By J. PAYN. Irurphy's Master. By J. PAYN. A County Family. By J. PAYN. At Her Mercy. By J. PAYN. AWoman'sVengeance. J.PAYN. Cecil's Tryst. By JAMES Payn. The Clyffards of Clyffe. J.PAYN. Family Soapegrace. J. PAYN. The Foster Brothers. J. PAYN. Found Dead. By JAMES PAYN. Gwendoline'sHarvest. J.PAYN. Humorous Stories. J. PAYN. Like Father, Like Son. J.PAYN. A Marine Residence. J. PAYN. Married Beneath Him.J.PAYN. Mirk Abbey. By JAMrS PAYN. Not Wooed, but Won. J. PAYN. Two Hundred Pounds Reward. By JAMES PAVN.

Bost of Eusbands. By J. PAYN. Woiter's Word. By J. PAYN. Elalves. By JAMES PAyN.

Fallen Fortunes. By J. PAYN. What He Cost Her. J. PAYN. Less Black than We'ro Painted. By James Payn.

By Proxy. By James Payn. Under One Roof. By J. Payn. High Spirits. By JAS. PAYN. Paul Ferroll.

Why P.Ferroll Killed his Wife. The Mystery of Mario Roget: By EDGAR A. Por. 
POPULAR Novels-continued.

Put Yourself in his Place. By Charles READE.

Her Mother's Darling. By Mrs. J. H. RIDDFLl.

Gaslight and Daylight. By George Augustus Sala.

Bound to the Wheel. By Jorn SAUNDERs.

Guy Waterman. J. Saunders. One Against the World By JOHN SAUNDERS.

The Lion in the Path. By Joris and KATHERINR SAUNDERS.

A Match in the Dark. By A, SkETCHLEY.

Fcap. 8vo, picture covers, 1s. each.

Jeff Briggs's Love Story. By BrET HARTE.

The Twins of Table Mountain. By Bret Hartr.

Mrs. Gainsborough's Diamonds. By Julian Hawthornz.

Kathleen Mavourneen. By the Author of "That Lass o' Lowrie's." Lindsay's Luck. By the Author of "That Lass o' Lowrie's."

Pretty Polly Pemberton. By Author of "That Lass o' Lowrie's." Trooping with Crows. By Mrs. PIRkIs.

The Professor's Wife. By Leonard Graham.

\section{Payn.-Some Private Views.}

Being Essays contributed to The Nineteenth Century and to The Times. By JAmes PAYN, Auttor of "High Spirits," "By Proxy," "Lost Sir Massingberd," \&c.

[Nearly ready. Two Vols. 8vo, cloth extra, with Portraits, ros. $6 d$.

Plutarch's Lives of Illustrious Men.

Translated from the Greek, with Notes, Critical and Historical, and a Life of Plutarch, by JOHN and WILLIAM LANGHORNE.

Crown 8vo, cloth extra, with Portrait and Illustrations, $75.6 \%$
Poe's Choice Prose and Poetical Works. With BAudelaire's " Essay."

Crown 8vo, cloth extra, 7s. 6d.

Primitive Manners and Customs.

By JAMES A. FARRER.

Small 8vo, cloth extra, with r 30 Illustrations, 3 s. $6 d$.

Prince of Argolis, The:

A Story of the Old Greek Fairy Time. By J. Moyr Smirk.

Crown 8vo, cloth extra, g;
Pursuivant of Arms, The;

or, Heraldry founded upon Facts. By J. R. PLANChb, Somerset Herald, With Coloured Frontispiece and 200 Illustrations. 


\section{Proctor's (R. A.) Works:}

E\&sy Star Lessons. With Star Maps for Every Night in the Year, Drawings of the Constellations, \&C. By Richard A. PROctor. Crown 8vo, cloth extra, 6s.

Familiar Science Studies. By RICHARd A. Proctor. Crown $8 \mathrm{vo}$, cloth extra, $75.6 d$. [In the press,
[I Saturn and its System. Fy RICHARD A. Proctor. New and Revised Edition, demy 8vo, cloth extra, 12s. 6\%. [In preparation.

Meyths and Marvels of Astronomy. By Rich. A. Proctor, Author of "Other Worlds than Ours," \&c. Crown 8vo, cloth extra, 6s.

Pleasant Ways in Scienco. By R. A. Proctor. Cr.8vo, cl. ex.6s.

Rough Ways made Smooth: A Series of Familiar Essays on Scientific Subjects. By R. A. Proctor. Crown 8vo, cloth extra, $6 s$.

Our Plice among Infinities: A Series of Essays contrasting our Little Abode in Space and Time with the Infinities Around us. By kichard A. Proctor. Crown 8vo, cloth extra, 6s.

The Fxpanse of Hesven: A Series of.Essays on the Wonders of the Firmament. By Ricrard A. Proctor. Crown 8vo, cloth, $6 s$.

Wages and Wants of Science Workers. By RicHARD A. Proctor. Crown 8vo, is. $6 d$.

Rabelais' Works.
Crown; 8vo, cloth extra, with lllustrations, 7s. $6 d$.

Faithfully Translated from the French, with variorum Notes, and numerous characteristic Illustrations by GUSTAVE DORE.

Crown 8vo, cloth gilt, with numerous Illustrations, and a beautifully executed Chart of the various Spectra, 7s. $6 d$.

\section{Rambosson's Popular Astronomy.}

By J. Rambosson, Laureate of the Institute of France. Translated by C. B. Pitman. Profusely Illustrated.

Second Edition, Revised, Crown 8vo, 1,200 pages, half-roxburghe, 12s. $6 d$. Reader's Handbook (The) of Allusions, References, Plots, and Stories. By the Rev, Dr. Brewer.

\section{Crown 8vo, cloth extra, 6s.}

Richardson's (Dr.) A Ministry of Health, and other Papers. By BENJAMIN WARD RICHARDSON, M.D., \&c.

\section{Rimmer (Alfred), Works by:}

Our Old Country Towns. With over 50 Illustrations. By AlFred Rimmer. Square 8vo, cloth extra, gilt, ros. $6 \dot{d}$.

Rambles Round Fton and Harrow. By ALFRED RIMMER. With 50 Illustrations by the Author. Square 8vo, cloth gilt, ros. $6 d$.

About Fngland with Dickens. With Illustrations by ALFRED RIMMER and C. A. VANDERHOOF, Sq. 8vo, cloth gilt, 10s. 6d. [In the press.

\section{Roll of Battle Abbey, The; \\ Handsomely printed, price 5 s.}

or, A List of the Principal Warriors who came over from Normandy with William the Conqueror, and Settled in this Country, A.D. I066-7. With the principad Arms emblazoned in Gold and Colours. 
Two Vols., large 4to, profusely Illustrated, half-morocco, $\mathrm{E}^{2} \mathrm{I \sigma s}$. Rowlandson, the Caricaturist.

A Selection from his Works, with Anecdotal Descriptions of his Famous Caricatures, and a Slwetch of his Life, Times, and Contemporaries. With nearly 400 Illustrations, mostly in Facsimile of the Originals. By JOSEPH GREGO, Author of "James Gillray, the Caricaturist ; his Life, Works, and Times."

Crown 8vo, cloth extra, profusely Illustrated, 4 s. $6 d$. each.

"Secret Out" Series, The.

The Pyrotechnist's Treasury; or, Complete Art of Making Fire. works. By ThomAs KENTISH. With numerous Illustrations.

The Art of Amusing :

A Collection of Graceful Arts, Games, Tricks, Puzzles, and Charades. By FraNk Bellew, 300 Illustrations. Zanky-Panky :

Very Easy Tricks, Very Difficult Tricks, White Magic, Slelght of Hand. Edited by W.H.CREMER. 200 Illusts. The Merry Cirole:

A Book of New Intellectual Games and Amusements. By Clara BrLlew. Many Illustrations.
Maglcian's Own Bools:

Performances with Cups and Balls, Eggs, Hats, Handkerchiefs, \&c. All from Actual Experience. Edited by W. H. Crhmer. 200 Illustrations.

Magio No Mystery :

Tricks with Cards, Dice, Balls, \&c, with fully descriptive Directions; the Art of Secret Writing; Training of Performing Animals, \&c. Coloured Frontisplece and many Illustrations.

The Secret Out :

One Thousand Tricks with Cards, and other Recreations; with Entertaining Experiments in Drawing-room or "White Magic." By W. H. CKRMER. 300 Engravings.

\section{Crown 8vo, cloth extra, 6s.}

Senior's Travel and Trout in the Antipodes. An Angler's Sketches in Tasmania and New Zealand. By WILLIAM SENIOR ("Red Spinner"), Author of "By Stream and Sea."

\section{Shakespeare:}

Shakespeare, The First Folio. Mr. William Shakespeare's Comedies, Histories, and Tragedles. Published according to the true Originall Copies. London, Printed by IsAac IAGgard and ED. BLOUNT, 1623. - A Reproduction of the extremely rare original, in reduced facsimila by a photographic process-ensuring the strictest accuracy in every detail. Small 8vo, half-Roxburghe, $7^{s}$. $6 d$.

Shakespeare, The Lansdowne. Beautifully printed in red and black, In small but very clear type. With engraved facsimile of Droeshour's Portrait. Post 8vo, cloth extra, 7s. 6 \%.

Shakespeare for Children: Tales from Shakespearo. By. Charlis and MARY LAMB. With numerous Illustrations, coloured and plain, by J. Movr Smith. Crown 4 to, cloth gilt, ros. $6 d$.

Shakespeare Music, The Handbook of. Being an Account of 350 Pieces of Music, set to Words taken from the Plays and Poems of Shakespeare, the compositlons ranging from the Elizabethan Age to the Present Time. By ALFRED ROFFE. 4to, balf-Roxburghe, 75 .

Shakespeare, A Study of. By Algernon Charlis SwiN. BURNE, Crown 8 vo, cloth extra, 85 . 
Crown 8vo, cloth extra, gilt, with Io full-page Tinted Illustrations, 75. 6.3. Sheridan's Complete Works,

with Life and Anecdotes. Including his Dramatic Writings, printed from the Original Editions, his Works in Prose and Poetry, Translations, Speeches, Jokes, Puns, \&c. ; with a Collection of Sheridaniana.

Signboards :

Crown 8 vo, cloth extra, with roo Illustrations, 7s. $6 d$.

Their History. With Anecdotes of Famous Taverns and Remarkable Characters." By JACOB LARwOOD and JOHN CAMDEN HOTTEN. Crown 8vo, cloth extra, gilt, 6s. $6 d$.

Slang Dictionary, The:

Etymological, Historical, and Anecdotal. An ENTIRELY NEW EDITION, revised throughout, and considerably Enlarged.

Exquisitely printed in miniature, cloth extra, gilt edges, 2s. $6 d$. Bmolker's Text-Book, The. By J. Hamer, F.R.S.L. Crown 8vo, cloth extra, $5^{5}$.

Spalding's Plizabethan Demonology:

An Essay in Il'sstration of the Belief in the Existence of Devils, and the Powers possessed by them. By T. AlFred SPALding, LL.B.

Crown 4to, uniform with "Chaucer for Children," with Coloured Ilustrations, cloth gilt, Ios. $6 d$.

Spenser for Children.

By M. H. Town R. Illustrations in Colours by WALTER J. MORGAN. A New Edition, small crown 8 vo, cloth extra, 5 s.

Staunton.-Laws and Practice of Chess;

Together with an Analysis of the Openings, and a Treatise on End Games. By Howard Staunton. Edited by Robert B. Wormald.

Stedman's Victorian Poets :

\section{Crown 8vo, cloth extra, 9 s.}

Critical Essays. By Edmund Clarence Stedman.

Stories about Number Nip,

\section{Post 8 vo, cloth extra, 5 s.}

The Spirit of the Giant Mountains. Retold for Children, by WALTER

GRAHAME. With Illustrations by J. MOYR SMITH. Two Vols., crown 8 vo, cloth extra, 2 Is.

Stories from the State Papers.

By Alex. Charles Ewald, F.S.A., Author of "The Life of Prince Charles Stuart," \&c. With an Autotype Facsimile.

Two Vols., arown 8vo, with numerous Portraits and Illustrations, 245.

Strahan.-Twenty Years of a Publisher's Life. By Alexander Strahan.

[In the press. 


\section{Crown 8vo, cloth extra, with Illustrations, 7s. $6 d$.}

Strutt's Sports and Pastimes of the Peoplo of England; including the Rural and Domestic Recreations, May Games, Mummeries, Shows, Processions, Pageants, and Pompous Spectacles, from the Earliest Period to the Present Time. With $x_{4} 0$ Illustrations. Edited by WILLiAM HONE.

Crown 8vo, with a Map of Suburban London, cloth extra, 7s. 6d.

Suburban Homes (The) of London:

A Residential Guide to Favourite London Localities, their Society, Celebrities, and Associations. With Notes on their Rental, Rates, and House Accommodation.

\section{Swift's Choice Works,}

In Prose and Verse. With Memoir, Portrait, and Facsimiles of tho Maps in the Original Edition of "Gulliver's Travels."

\section{Swinburne's Works:}

The Queen Mother and Ross. mond. Fcap. $8 \mathrm{vo}, 5$ s.

Atalanta in Calydon.

A New Edition. Crown 8vo, 6s.

Chastelard.

A Tragedy. Crown 3rn, 7s.

Poems and Ballads.

First Szrins. Fcap. 8vo, gs. Also in crown 8vo, at same price.

Pooms and Ballads.

Stcond Series. Fcap. 8vo, 9s. Also in crown 8vo, at same price.

Notes on "Poems and Bal. lads." 8vo, is.

William Blake :

A Critical Essay. With Facsimile Paintings. Demy 8vo,' $16 s$.

Songs before Sunrise.

Crown 8vo, ros. $6 d$. MR. SWINBURNE'S NEW DRAMIA.-Crown 8vo, cloth extra, is.

Mary stuart: A Tragedy, in Five Acts. By Algernon Charles SWINBURNE.

\section{Sword, The Book of the :}

Demy 8vo, cloth extra, Illustrated, 2Is.

Bothwell :

Tragedy. Crown 8vo, i2s. 64.

Chapman:

An Essay. Crown 8vo, 7s.

Songs of Two Nations.

Crown 8vo, 6s.

Fssays and Studles.

Crown 8vo, r2s.

Frechtheus :

A Tragedy. Crown 8vo, 6s.

Note of an Fnglish Republioan on the Muscovite Crusade. 8ro, Is.

A Note on Charlotte Brontë. Crown 8vo, 6s.

A Study of Shakespeare. Crown 8vo, 8 s.

Songs of the Springtides. $\mathrm{Cr}$. $8 v o, 6 s$.

Studies in Song.

Crown $8 \mathrm{vo}, 7 s$.

Being a History of the Sword, and its Use, in all Times and in all Countries. By Captain RICHARD BURTON. With numerous Illustrations.

In preparation.

Syntax's (Dr.) Three Tours,

in Search of the Picturesque, in Search of Consolation, and in Search of a Wife. With the whole of RowLANDSON's droll page Illustra. tions, in Colours, and Life of the Author by J. C. HoTTEN. 
Four Vols. small 8vo, cloth boards, 305.

\section{Taine's History of English Literature.}

Translated by Henry VAN LAUN.

- Also a Popular Edition, in Two Vols. crown 8vo, cloth extra, i5s. Crown 8vo, cloth gilt, profusely Illustrated, 6 s.

Tales of Old Thule.

Collected and Illustrated by J. MOYR SMITH.

One Vol. crown 8vo, cloth extra, $75.63:$
Taylor's (Tom) Historical Dramas:

"Clancarty," "Jeanne Darc," " "Twixt Axe and Crown," "The Fool's Revenge," "Arkwright's Wife," "Anne Boleyn," "Plot and Passion." * * The Plays may also be had separately, at 18. $\theta$ ach.

Crown 8vo, cloth extra, with Coloured Frontispiece and numerous

\section{Thackerayana:} Illustrations, $75.6 d$.

Notes and Anecdotes. Illustrated by a profusion of Sketches by WILLIAM MAKEPEACE THACKERAY, depicting Humorous Incidents

- In his School-life, and Favourite Characters in the books of his every. day reading. With Hundreds of Wood Engravings, facsimiled from Mr. Thackeray's Original Drawings.

Crown 8vo, cloth extra, gilt edges, with Illus,rations, $7 s .6 d$.

Thomson's Seasons and Castle of Indolence. With a Biographical and Critical Introduction by ALLAN CUNNINGHAM, and over 50 fine Illustrations on Steel and Wood.

Crown 8vo, cloth extra, with numerous Illustrations, $75,6 d$.

Thornbury's (Walter) Haunted London.

A New Edition, Edited by EDWARD WALFORD, M.A., with numerous Illustrations by F. W. FAIRHOLT, F.S.A.

Timbs' Clubs and Club' Life in London.

With Anecdotes of its famous Coffee-houses, Hostelries, and Taverns. By JOHN TIMBS, F.S.A. With numerous Illustrations.

Timbs' Fnglish Eccentrics and Eccentricities: Stories of Wealth and Fashion, Delusions, Impostures, and Fanatic Missions, Strange Sights and Sporting Scenes, Eccentric Artists, Theatrical Folks, Men of Letters, \&c. By JoHN TrMBs, F.S.A. With nearly 50 Illustrations.

\section{Torrens' The Marquess Wellesley,}

Architect of Émpire. An Historic Portrait. Forming Vol, 1. of ProCoNsul and Tribune: Wellesley and O'Connell: Histortc Portraits. By W. M. TorRens, M.P. In Two Vols. 
Demy $8 \mathrm{vo}$, cloth extra, with Illustrations, $9 s$.

Tunis: the Land and the People.

By ERNST VON HESSE-WARTEGG. With many fine full-page Illustrations.

[in the press.

Crown 8vo, cloth extra, with Coloured Illustrations, 7s.6d.

Turner's (J. M. W.) Life and Correspondence:

Founded upon Letters and Papers furnished by his Friends and fellowAcademicians. By WALTER ThORnBuRY. A New Edition, con. siderably Enlarged. With numerous Illustrations in Colours, facsimiled from Turner's original Drawings.

Two Vols., crown 8vo, cloth extra, with Map and Ground-Plans, I4s.

Walcott's Church Work and Life in Finglish Minsters; and the English Student's Monasticon. By the Rev. MACKENZIE E. C. WALCOTT, B.D.

Walton and Cotton's Complete Angler; or, The Contemplative Man's Recreation ? being a Discourse of Rivers, Fishponds, Fish and Fishing, written by IzAAK WALTON; and Instructions how to Angle for a Trout or Grayling in a clear Stream, by CHARLES COTTON. With Original Memoirs and Notes by Sir HARRIS NiCOLAs, and 6r Copperplate Illustrations.

The Twenty-second Annual Edition, for I88r, cloth, full gilt, 50s.

Walford's County Families of the United Kingdom. BY.EDWARD WALFORD, M. A. Containing Notices of the Descent, Birth, Marriage, Education, \&c., of more than I2,000 distinguished Heads of Families, their Heirs Apparent or Presumptive, the Offices they hold or have held, their Town and Country Addresses, Clubs, \&c.

Wanderer's Library,

Merrie England in the Olden

Time. By GEORGE DAN̂̃iez. With

Illustrations by ROBT. Cruikshank.

The Old Showmen and the Old

London Fairs. By Thомas Frost.

The Wilds of London. By James GreEnwOOd.

TavernAnecdotes and Sayings; Including the Origin of Signs, and Reminiscences counected with Taverns, Coffee Houses, Clubs, \&c. By Charles Hindley. With Illusts.

Circus Life and Circus Celebri. ties. By Thomas Frost.

The Lives of the Conjurers. By ThONAS Frost.

The Life and Adventures of a Cheap Jack. By One of the Fraternity. Edited by Charles Hindley. The Story of the London Parks. By JACOB LARWOOD. With Illusts.

\section{ra, 3s. 6d. per volume.}

The :

Low-Life Deeps. An Account of the Strange Fish to be found there. By JAMES GREzNWOOD.

Seven Generations of Frecu. tioners: Memoirs of the Sanson Family (1688 to 1847). Edited by HENRY SANSON.

The World Behind the Scenes. By Percy Fitzgerald.

London Characters. By HeNkY MAYHEw. Illustrated.

The Genial Showman: Life and Adventures of Artemus Ward. By E. P. Hingston. Frontispiece.

Wanderings in Patagonia; or, Life among the Ostrich Hunters. By Julius BEERBOHM. Illustrated.

Summer Cruising in the South Seas. By Charles Warren StodDARD. Illustrated by WALLIS MACKAY. 
Carefully printed on paper to imitate the Original, 22 in. by 14 in., 25.

Warrant to Execute Charles I.

An exact Facsimile of this important Document, with the Fifty-nine Signatures of the Regicldes, and corresponding Seals.

Beautifully printed on paper to imitate the Original MS., price $2 s$.

Warrant to Fxecute Mary Queen of Scots.

An exact Facsimile, including the Signature of Queen Elizabeth, and a Facsimile of the Great Seal.

Crown 8vo, cloth limp, with numerous Illustrations, 45. 6d.

Westropp's Handbook of Pottery and Porcelain ; or, History of those Arts from the Earliest Period. By HODDER M. WESTROPP. With numerous Illustrations, and a List of Marks.

\section{What shall my Son be?}

Post 8vo, cloth limp, 2s. $6 d$.

Hints for Parents on the Choice of a Profession or Trade for their Sons. By Francis Davenant, M.A.

\section{Whistler $\nabla$. Ruskin: Art and Art Critics.} By J. A. MACNEILL WHISTLER.

A VERY HANDSOME VOLUME.-Large 4to, cloth extra, srs. $6 d$. White Mountains (The Heart of the):

Their Legend and Scenery. By SAMUEL ADAMS DRAKE. With nearly roo Illustrations by W. HAMILTON GiBson, Author of "Pastoral Days."

[Nearly ready.

Crown 8vo, cloth limp, with Illustrations, 2s. $6 d$.

Williams' A Simple 'Treatise on Heat. By W. MatTied Williams, F.R.A.S., F.C.S.

Small $8 v o$, cloth extra, Illustrated, $6 s$.

Wooing (The) of the Water-Witch:

A Northern Oddity. By Evan DALDORNE. Illust. by J. MOYR SMITH.

Words, Facts, and Phrases:

$$
\text { Crown 8vo, half-bound, r2s. } 6 d \text {. }
$$

A Dictionary of Curious, Quaint, and Out-of-the-Way Matters. By ELIEZER EDWARDS.

Wright's Caricature History of the Georges. (The House of Hanover.) With 400 Pictures, Caricatures, Squibs, Broadsides, Window Pictures, \&c. By Thomas Wright, M.A., F.S.A.

Large post 8vo, cloth extra, gilt, with Illustrations, 75. $6 d$.

Wright's History of Caricature and of the Grotesque in Art, Literature, Sculpture, and Painting. By Thomas Wright, F.S.A. Profusely Illustrated by F. W. FAIRHOLT, F.S.A.

J. OGDEN AND CO., PRINTRR, I72, ST, JOHN STREET, E.C. 
(4m

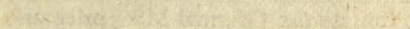

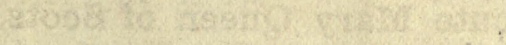

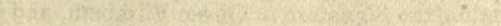

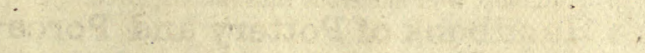

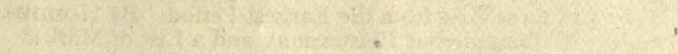

(46). .2

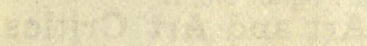

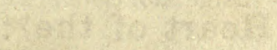

$\sin x$

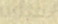

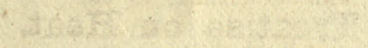

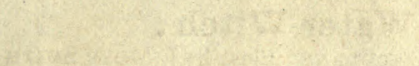

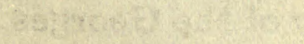

(4)

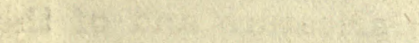


. 


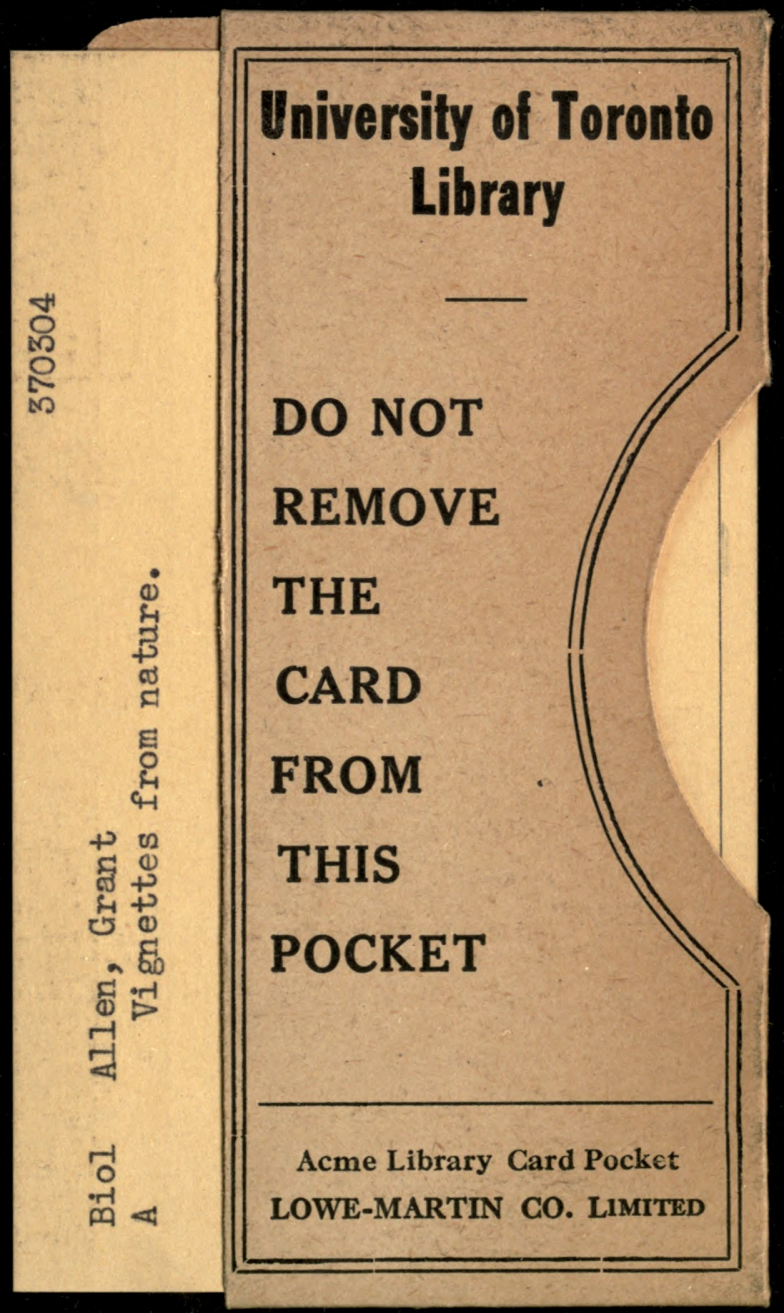


